DOI:10.30842/ielcp230690152256

Andrei Lebedev

\title{
THE DERVENI PAPYRUS AND PRODICUS OF CEOS ${ }^{1}$
}

To the memory of Martin West.

\begin{abstract}
А. В. Лебедев. Дервенийский папирус и Продик из Кеоса.
Статья посвящена авторству, жанровому определению, философской интерпретации, датировке и культурно-историческому контексту Папируса из Дервени (ДП), философского текста с цитатами из Орфической теогонии, найденному в могиле второй пол. 4 в. до н. э. в деревне Дервени у Салоник в 1962 г. В разделе (1) указываются причины ошибочных толкований и неверных атрибуций: ложное опреде-
\end{abstract}

1 This is a preliminary (abridged) presentation of the main results of our investigation of the Derveni papyrus the complete text of which will appear in the volume «Presocratics and Papyrological Tradition» (2019) edited by Christian Vassallo. The original version of this paper under the title «The Derveni Treatise as a Document of Sophistic Atheism» was presented at the International conference on the Derveni papyrus at Princeton University on April $25^{\text {th }}, 1993$ during my Perkins fellowship granted by the Council of Humanities of Princeton University (cf. Sider 1997: 129, n. 2). I have benefited from several discussions of my hypothesis. During my fellowship in All Souls College, Oxford (1995-1996) I was invited by Professor Richard Janko to present my «atheistic» interpretation of PDerv at his seminar in the Institute of Classical Studies, London on June $7^{\text {th }}$, 1996. Additional recent research was stimulated by the invitation to give a lecture «The Derveni papyrus and Greek Enlightenment» at the Department of Classics of New York University on November $3^{\text {rd }}, 2016$ (thanks are due to David Sider, Mirjam Kotwick and other colleagues who took part in the discussion) and by the participation at the International Colloquium «Presocratics and Papyrological Tradition», University of Trier, 2124 September 2016 organised by Christian Vassallo and Wolfgang Woehrle. Thanks are due to Valeria Piano for discussing with me on this occasion the possibility of some readings in PDerv. col. IV, line 6 (all remaining faults are mine) and to Christian Vassallo for sharing with me the complete text of his extremely important paper on Anaxagoras and atheism in doxography (Vassallo 2019). The documentary basis of this investigation relies on innumerable $T L G$ searches. Special thanks are due to Maria Pantelia, the director of TLG-project, who year after year provided me with immediate assistance whenever I experienced problems with access to $T L G$ on-line. I also wish to thank Nikolai Kazansky for his advice in matters of Greek dialectology and both him and Eugenia Kriuchkova for the restoration of the illegible Greek in the original version of this paper (1993). 
ление папируса как «орфического», а его автора - как орфика или орфеотелеста проистекают, в частности, из игнорирования существования двух типов пантеизма в раннегреческой мысли: этико-религиозного и натуралистического. Автор папируса был представителем второго типа, несовместимого с учением о бессмертии души и загробном воздаянии, характерным для пифагорействующего орфизма. Раздел (2) дает интеллектуальный портрет автора: ионийский софист 5 века до н. э. последователь Анаксагора и Архелая в космологии и физике, предлагающий «атеистическую» теорию происхождения религии «физика» Орфея и происхождение мифологических образов богов как «болезнь языка» или «ослышка» невежд. Сторонник софистической «орфоэпии» и адепт функционализма в семантике и теории номинации (имя соответствует «делу», ह̌рүоv, носителя), восходящей к Гераклиту, создал текст в жанре софистической истории происхожде-

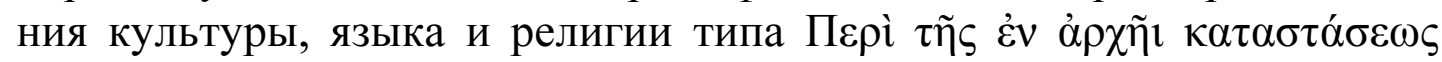
Протагора. Современники могли причислять взгляды автора ДП к «атеистическим». В разделе (3) обосновывается атрибуция ДП Продику из Кеоса и приводятся 19 testimonia: дословные цитаты из ДП у древних авторов с прямым упоминанием имени Продика, а также специфические особенности (прежде всего утилитаризм и «земледельческая〉 теория происхождения религии Продика (стлб. XXIV), черты языка и стиля. В разделе (4) предлагается новая реконструкция и интерпретация столбца IV с цитатой Гераклита о солнце. Содержащееся

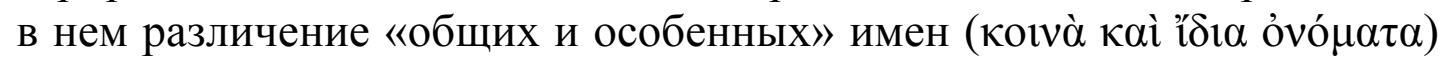
является основополагающим для понимания герменевтического метода автора ПД и его теории имен и возникновения мифологии. В разделе (5) анализируется не отмеченный прежде рефлекс теории Продика о происхождении религии из обожествления «полезного для жизни» в Меморабилиях Ксенофонта (2.2). Раздел (6) посвящен датировке и названию трактата. Предлагается отождествление с сочинением Продика «Времена года» или «Эпохи» (' $\left.\Omega \rho \alpha_{1}\right)$, посвященным происхождению человеческого рода и цивилизации. Наиболее вероятное время написания - 20-ые гг. 5 в. до н. э. Terminus post quem - псефизма Диопифа (432 г.) и процесс или смерть Анаксагора (428 г.). Terminus ante quem - «Птицы» Аристофана (414 г.), с пародией на аллегорическую интерпретацию Орфической теогонии Продиком, а не на саму Орфическую теогонию. Вместо «полезных факторов» Продика (светила, элементы, пища и др.) Аристофан в своем агоне с Продиком представляет птиц как приносящих человеческому роду больше пользы, этим обосновывается их победа над Продиком в качестве кандидата на роль новых богов. Вероятно ДП был «ответом» на псефизму Диопифа, направленную против Анаксагора и запрещавшую преподавать новую астрономию в Афинах. Делая Орфея древним анаксагоровцем, Продик смеялся над Диопифом и религиозными 
консеваторами, но одновременно предохранял себя от обвинения в

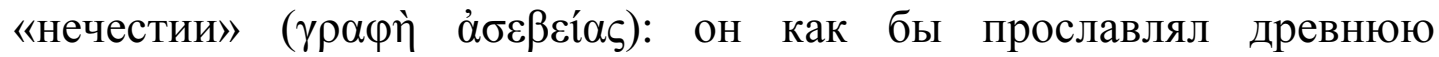
мудрость Орфея, учредителя религии и таинств, но только предлагал

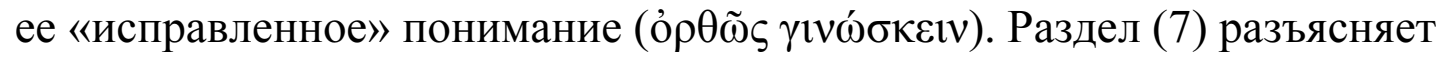

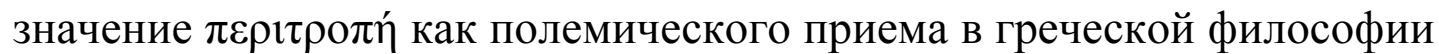
и предлагает понимать ДП как перитропу религиозного текста с полемической и пародийной целью.

Ключевые слова: Папирус из Дервени, Продик, Софисты, Орфизм, Анаксагор, Архелай, Гераклит, теогония, история цивилизации, происхождение религии, происхождение мифологии, происхождение языка, аллегория, псефизма Диопифа, атеизм античный, Греческое просвещение, философия языка, Древние Афины.

(1) Preliminary remarks. Why the Derveni papyrus has often been misread and misapprehended. Two types of pantheism in early Greek thought.

The failure of several unfortunate attempts to establish the authorship of the Dereveni papyrus has led the editors to a position of docta ignorantia, the denial of the very possibility of attribution ${ }^{2}$. We find such scepticism excessive and counterproductive. Any attribution of an anonymous text to be taken seriously should be based on precise and unambiguous evidence, first of all on verbatim quotations from the anonymous text in ancient authors with a direct mention of author's name. Apart from the verbatim quotations, references to particular ideas, tenets, theories etc. attested in the anonymous text and attributed by an external source to a certain writer (as well as his interests, specific subjects, literary habits, style, methodology etc.) will also count as evidence with the proviso that they are not too common and widespread, but rather peculiar (and best of all unique) to the supposed author. The attribution of PDerv to Prodicus proposed in this article meets these requirements: it is based on verbal coincidences of peculiar phrases and terms in PDerv and Prodicus' fragments; Prodicus' peculiar theory of the origin of the names of gods and religion from agriculture and other tekhnai «useful» for human race is directly attested in PDerv; there is also a combined direct evidence of Aristophanes and Themistius that Prodicus wrote an allegorical interpretation of the Orphic theogony.

\footnotetext{
${ }^{2}$ Kouremenos in KPT 2006: 58-59. The sceptical attitude is shared by Betegh 2004: 349 and Kotwick 2017: 22 among others. The edition of Kouremenos, Parassoglou and Tsantsanoglou (2006) is henceforward quoted as $K P T$.
} 
The demonstration of our thesis is presented below in six thematic sections.

Section (2) deals with the literary genre, the general purpose and the hermeneutical method of the Derveni treatise, and draws a preliminary intellectual portrait of its author describing his peculiar features, a kind of a «composite image». In the section (3) we argue for Prodicus as the author of PDerv and present 18 testimonia on which this attribution is based. These include both the verbatim quotations with Prodicus' name that find an exact correspondence in the text of PDerv and the common peculiar features of the language and style. The 19th testimonium is presented separately in section 5 since it contributes to the commentary in the preceding section. In the section (4) we propose a reconstruction and interpretation of the text of the col. IV that contains a quotation from Heraclitus. This column is of primary importance for the understanding of the aims and allegorical method of the author in general as well as for his theory of names. Section (5) detects a neglected (polemical) peritrope of Prodicus' benefaction theory of the origin of religion in Xenophon's Memorabillia 4.4. In the section (6) the problems of the original title and date of the Derveni treatise are addressed, as well as its relation to the Psephisma of Diopeithes (432 BC) and the trial and death of Anaxagoras. The last section (7) clarifies our use of the term peritrope and explains the Derveni treatise as a polemical naturalistic peritrope of a religious text (Orphic theogony).

The Derveni papyrus has been often misread and misapprehended for the following main reasons. (1) First, because a wrong label «Orphic» was attached to the papyrus in the very first report (Kapsomenos 1964). (2) Second, because another misleading label «Presocratic» was soon after that attached to its author (Burkert 1968). (3) Third, because the rhetorical/grammatical terms of the

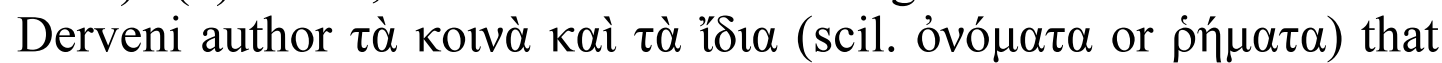
provide a clue for the understanding of his theory of language and of the origin of religion, have been misunderstood as alleged «echoes» of Heraclitus' own terminology (this mistake is dealt with in section 4). (4) Fourth, because of the failure to distinguish between two types of pantheism in early Greek thought, the naturalistic and the ethico-religious pantheism. (5) Fifth, because of the failure to distinguish two types of allegoresis of myth: a constructive (friendly and apologetical in purpose) and a deconstructive (polemical or atheistic) which is the case of PDerv. (6) And, last but not least, the widespread (after Tsantsanoglou 1997) misinterpretation of $\pi \alpha ́ \rho \mu \varepsilon v$ 
in col. V. as an alleged indication of the author's religious profession (dealt with in section 2 below, with notes 26-29).

We have on different occasions since 1989 criticised the term «Presocratic/Presocratics» both for its chronological incongruities (if Presocratics were philosophers of the 6th and 5th centuries B.C., then was Socrates «Presocratic»?) and for its physicalist bias that has led to the serious misunderstanding of the Western Greek idealist metaphysics (Pythagoreans and Eleatics) and to the no less serious distortion of the general picture of what happened in early Greek thought before 400 B.C. (Lebedev 1989) ${ }^{3}$. The Derveni papyrus is a remarkable case at point: it provides a clear example of how this artificial and misleading modern term can bewilder scholars because of its surreptitious «interference» with authentic

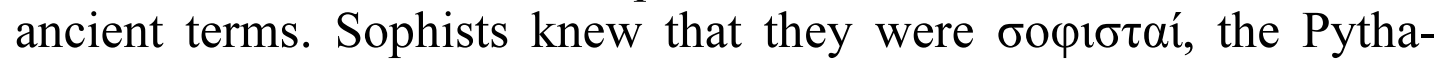

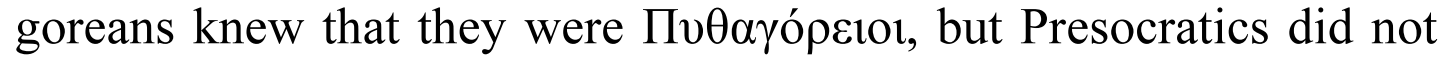
know that they were «Presocratics» (and fortunately so). Ancient sophists like Protagoras and Prodicus were contemporaries of the so called «Presocratics» like Anaxagoras or Archelaus and held very similar doctrines about the nature and the cosmos. But although included in Diels' edition of Vorsokratiker, the sophists are usually not referred to by this term: since «Presocratics» are thought to be cosmologists and physikoi, and sophists are not, the latter are commonly treated as a special group of «Sophists». That is why scholars, misguided by the label «Presocratic», turned away from the most obvious and promising group of candidates for the authorship of PDerv, the Ionian Sophists.

\footnotetext{
${ }^{3}$ A summary of my views in «Getting rid of the Presocratics» (Lebedev 2009). A defence of the ancient (and modern ante-Burnet) idealist interpretation of the metaphysics of Parmenides and the Pythagoreans in Lebedev $2017_{2}$ and Lebedev $2017_{3}$ respectively. The validity of the term «Presocratics» has been with good reasons question by Salomo Luria (С. Я. Лурье) starting from the 1920-ies (1970: 5 ff.) and by Tony Long in his preface to the "Cambridge Companion to Early Greek philosophy». Late Martin West, after reading with approval my (2009) paper «Getting rid of the «Presocratics» replied: «What you say about the Presocratics corresponds to what I have always thought. Forty-six years ago I wrote (CQ 17, 1967, 1 n. 2): «The term 'Presocratics' has so established itself that we should greatly inconvenience ourselves by abandoning it now. But it has two grave disadvantages: it exaggerates the effect of Socrates; and it lumps together an assortment of people, priests, doctors, vagabond poets, experimental physicists, whose methods and intentions were very various, and implies that they were somehow united in a common search» (letter to Andrei Lebedev from March 2, 2013).
} 
In our opinion, it is necessary to distinguish two types of pantheism in early Greek thought. Both rely on the equation deus $=$ natura, but interpret it in a different way: the naturalistic pantheism reduces god to nature, the ethico-religious pantheism reduces nature to god. The ethico-religious pantheism is ethically relevant, the omnipresence and omniscience of god is intended in it as a moral command, as a reminder of «timor Domini» and a warning «I am watching you!» The naturalistic pantheism is akin to the deism and may have been perceived by the ordinary Greeks as asebeia and atheism. When Aristotle (Phys. 203b13) ascribes to «Anaximander and the most of the physiologì the doctrine of the infinite matter as

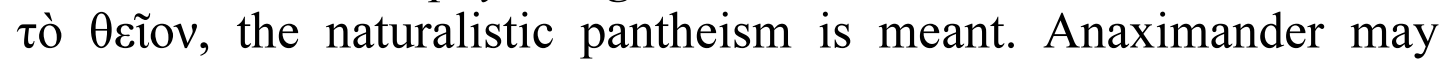
have described his «boundless nature» (

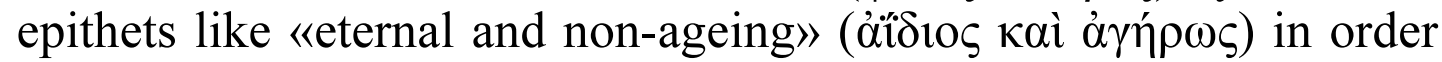
to emphasise that it is eternal and indestructible, but he hardly prayed to it or to the cosmogonical vortex it produced ${ }^{4}$. The pantheistic thesis «all is full of gods» ( $\pi \alpha \dot{v} \tau \tau \alpha \pi \lambda \eta \dot{\eta} \eta \theta \varepsilon \tilde{\omega} v)$ ascribed by Aristotle to Thales (De an. 411a7), is related with his

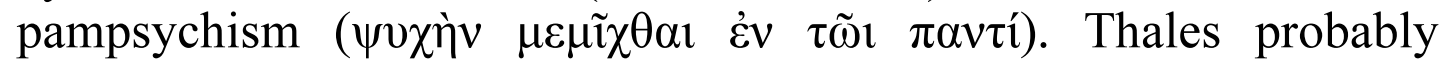
proved this thesis by adducing empirical evidence (tekmeria, D.L. 1.24), such as the attractive force of magnet and amber. Even if Thales regarded these forces as «divine» it is doubtful that he ever prayed to them or feared their wrath. This is naturalistic pantheism. A classical example of the ethically relevant religious pantheism is precisely the Orphic «hymn to Zeus» that followed the kataposis scene and the absorbtion of the Protogonos by Zeus in the Orphic theogony. The naturalistic pantheism is of Milesian origin, the ethico-religious pantheism derives from Xenophanes (with Pythagorean antecedents?) and Heraclitus (followed by the Stoics). In Xenophanes' monotheistic poem god «sees as a whole, perceives as whole, hears as whole» (21 B 24), according to another fragment quoted by Philoponus nothing escapes his notice, nor even a hidden thought in the heart of a man ${ }^{5}$. The Derveni author perfectly understood the difference between these two types of pantheism. He definitely does not believe that the «air» we inhale monitors our thoughts and will punish our sins in Hades. In a brilliant polemical

\footnotetext{
${ }^{4}$ Against the authenticity of the term $\tau$ ò ö $\pi \varepsilon 1 \rho o v:$ Lebedev 1978; mechanistic physics: Lebedev 1988 1 :57-58, vortex in cosmogony: Lebedev 2016: $597-598$.

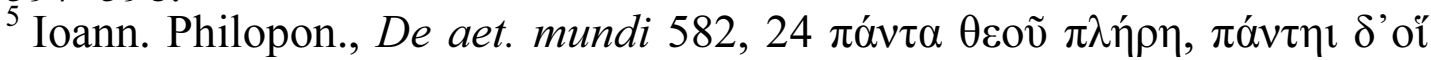

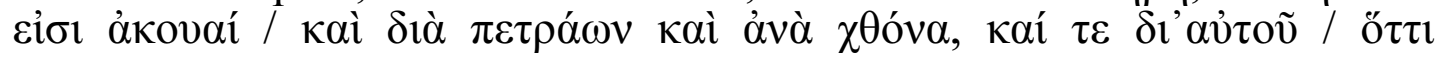

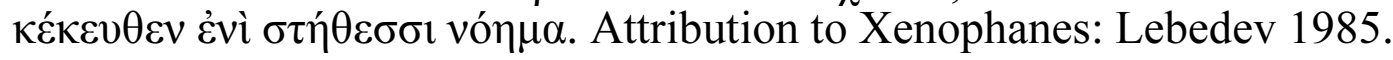


peritrope he substitutes the Ionian naturalistic pantheism for the Western Greek «Orphic» ethico-religious pantheism ${ }^{6}$.

We distinguish the terms «Derveni papyrus» (PDerv) and «Derveni treatise» (DervT). The Derveni papyrus is a document which we quote by the column and line of the official edition $(\mathrm{KPT})^{7}$. By the «Derveni treatise» we mean the original Sophistic text of the 5th century which can be reconstructed on the basis both of the extant columns of PDerv and other testimonia discussed in section (3) which partly supplement our knowledge of the lost integral text. The Derveni treatise is a kind of a reconstructed «archetype» of which the extant PDerv is the best and most important preserved «manuscript».

(2) The purpose, literary genre and the hermeneutical method of the Derveni treatise. A philosophical portrait (composite image) of the Derveni Author.

It has been thought that the Derveni author is quoting Orphic verses because he is interested in the Orphic religious doctrine, was an Orphic initiate or even an Orphic priest (Orpheotelestes), a diviner or a religious specialist himself. To reconcile this with some strange remarks of the author about mysteries, it has been suggested that he is an enlightened Orphic writing for a local Orphic community and trying to achieve a synthesis of the Ionian philosophy and Orphic faith. However, from the Greek point of view, the

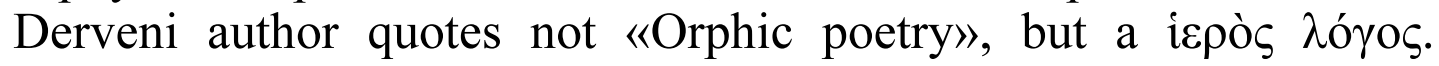
Classical authors avoid to quote verbatim Orpheus' verses, that is why the bulk of the extant fragments comes from late antiquity when the Neoplatonists made the Orphic theogony a Hellenic Bible in their fight against the Christian apologists. It is impossible to explain away col. XX as a criticism of superstition only, by comparing it, say, with Hippocratic De morbo sacro, 2. The Hippocratic doctor does not attack the public cult. The Derveni author does. In col. XX he makes derogatory and blasphemous remarks about the mystery cults expressed with mockery and sarcasm. The $\tau \dot{\varepsilon} \chi \nu \eta \nu$

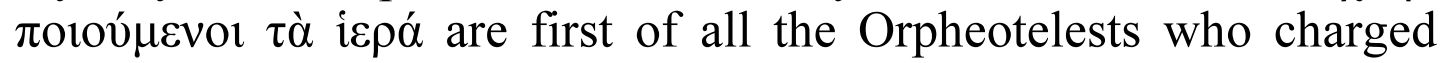
fees for the rites of initiation. How could an «Orphic» priest or an initiate ridicule his own profession and faith?

\footnotetext{
${ }^{6}$ On the meaning of peritrope as polemical device see section (7) below.

${ }^{7}$ We cite Janko's new text (2017) from Kotwick 2017.
} 
It has been rightly pointed out that his interest in Orphic poetry is neither grammatical, nor philological ${ }^{8}$. He does not seem to be interested in the text of the Orphic theogony as such. He is not an allegorist in the usual sense of the word, either. The mainstream philosophical allegorism from Theagenes on has been usually apologetic in purpose. The purpose of an allegorical interpretation is to construct a coherent referential subtext, that will exist side by side with the «surface» text without destroying it, and even "saving» it (Brisson 2004). The Derveni author does exactly the reverse: he systematically destroys myths; he does this not because he is an unskilled or bad interpreter, but because this is the purpose of his work. He therefore is not an awkward allegorist, but an intelligent and skilful irreligious rationalist. His allegorical interpretation of the Orpheus' theology, similar with the naturalistic «meteoroleschia» in Aristophanes' Clouds and the physical gods-elements of the philosophers mocked by Epicharmus (Lebedev 20174), belongs to the deconstructive type. An example of the deconstructive naturalistic allegoresis of the Orphic theogony is provided by the sixth Homilia of the Pseudo-Clementina (see test. 19 in the section (3) below). The Christian apologists who reduced the Hellenic gods to the elements and natural phenomena, did not intend «to save» them; their purpose was to exterminate them, to expose them as nugatory or to proclaim them evil daimones ${ }^{9}$. Sometimes deconstructive allegoresis and scientific explanation are hard to distinguish, as in Xenophanes B 32

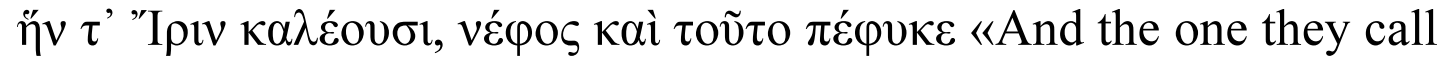
Iris is (just) a cloud, too...». This verse comes from a series of demythologised pseudo-gods of the poets. Heraclitus' use of the etymological allegory and of functionalist semantics may have been deconstructive with regard of the anthropomorphic polytheism of the poets, but by no means atheistic, since it was only a prelude to the new ethico-religious monotheism. The same holds true for the Stoics, although they may have been less iconoclastic than Heraclitus in their attitude towards the poetic myth. Some sophists (Protagoras and Prodicus) may have mistaken Heraclitus' criticism of popular religion for a kind of atheism.

The Derveni author is interested not so much in the Orphic poetry, as in Orpheus himself. It is the figure of Orpheus in the

\footnotetext{
${ }^{8}$ According to Martin West (1983) 190 the author's interest in the Orphic text «is wholly philosophical, not philological».

${ }^{9}$ For a more positive attitude towards Greek myth of the Byzantines see Brisson (2004), ch.7.
} 
DervT that reveals the personality of the author and gives a key to the understanding of the purpose of his book.

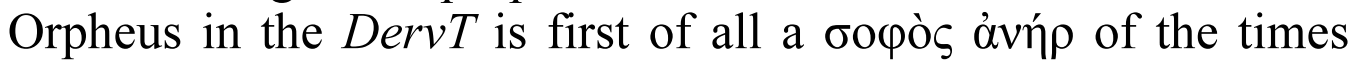
immemorial, a prehistoric sage who invented religion and established the sacred rites (teletai) ${ }^{10}$. Secondly he is the Onomatothetes who first established the divine names. Thirdly, he is an ápxaios

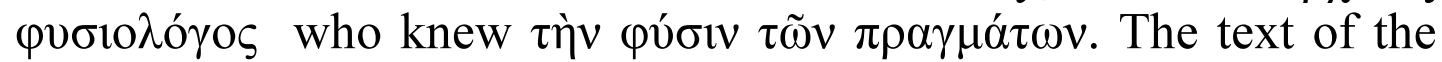
Orphic Theogony is used in the DervT only as a historical evidence for the reconstruction of Orpheus' work and philosophy as well as of the original religion of the primitive people. Like poetry, rituals also preserve the original wisdom of Orpheus. The third class of evidence used by the Derveni author are proverbial expressions, $\varphi \alpha ́ \tau \varepsilon 1 \varsigma$ taken as «remnants of ancient wisdom» ${ }^{11}$. This image of a prehistoric rationalist philosopher who replaces traditional Greek

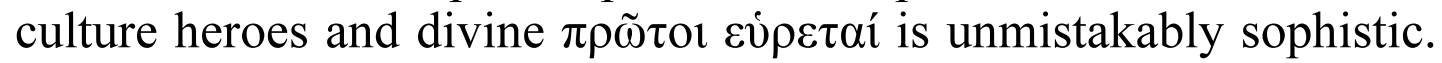

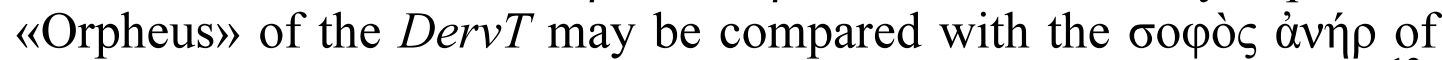
the play «Sisyphos» (probably by Critias) who invented religion ${ }^{12}$; with Cheiron the Centaurus in Euripides' Melanippe the Wise, a prehistoric astronomer and Anaxagorean philosopher ${ }^{13}$; with Heracles

${ }^{10}$ Kritias B 25 DK = Sext.Math. 9.54.

${ }^{11}$ The idea that the proverbs are «survivals» of the ancient wisdom cf.

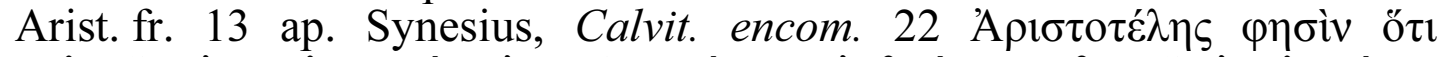

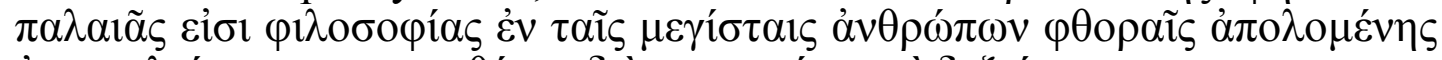

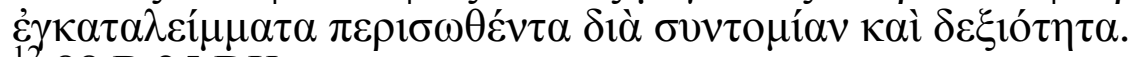

1288 B 25 DK.

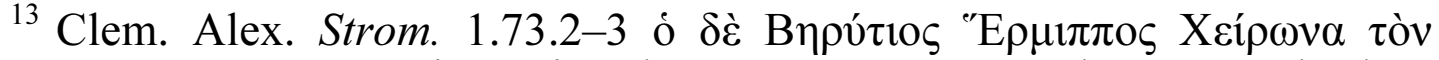

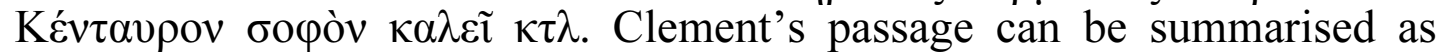
follows: just as according to Herodorus of Heraclea (fr. 13 Fowler),

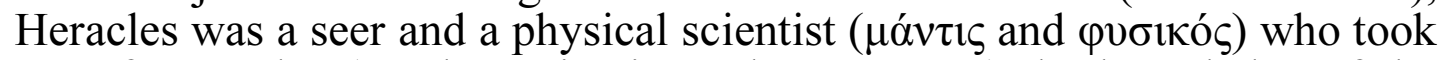
over from Atlas (another scientist and astronomer) the knowledge of the heavenly bodies allegorically interpreted as pillars of the cosmos (кíoves

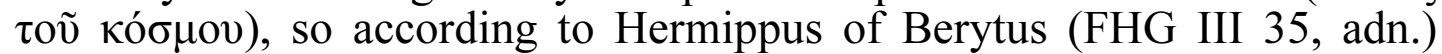
Cheiron was also an ancient astronomer and philosopher. From Cheiron the physical science ( taught it to Aeolus, a meteorologist «mastering» the winds by the power of his knowledge. Two poets are citedas $\mu \alpha \rho \tau$ ṕp of this remarkable construction: Titanomachia fr. 11 Bern. and Euripides, Melanippe the Wise fr. 11. Hippo-Hippe is the mother of Melanippe who expounds an Anaxagorean cosmogony in Eur. fr. $484=$ Anaxagor. A 62 DK. It is therefore conceivable that Cheiron the physiologos derives from a 5th century Anaxagorizing interpretation known to Euripides. The phraseology of Melanippe's logos is strikingly similar to PDerv col. XV, $2 \chi \omega \rho ı \theta \theta \dot{v} v \tau \alpha$

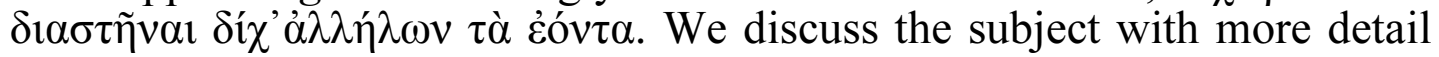
in: Lebedev 1998: 3-10. 


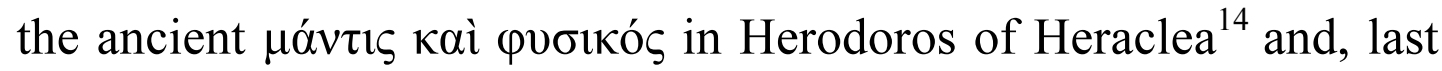
but not least, with Orpheus as an ancient philosopher and onomatothetes in Plato's Cratylus who runs a philosophical school of his

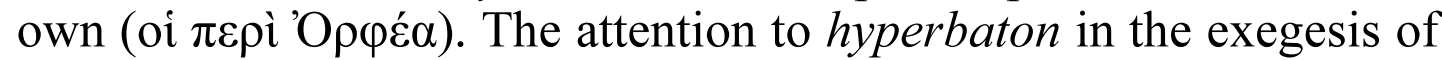
poets is a technique that Plato associates with Protagoras (Protagor. 339a sq.). The Derveni author takes for granted the sophistic antithesis of nomos and physis and he is apparently a specialist in the

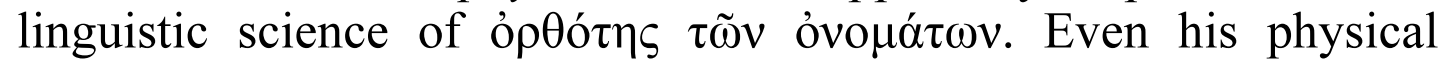
doctrine is Sophistic: Anaxagorean physics as modified by Archelaus (and possibly Democritus) who may be considered the father of the Kulturgeschichte: in his Peri physeos the Ionian cosmogony for the first time was continued by an archaeologia which discussed the origin of nomoi and of the human language ${ }^{15}$.

The theory of names of the Derveni author is of primary importance for the understanding of his hermeneutical method and of his theory of the origin of religion. It is based on the distinction between $\tau \grave{\alpha}$ ' $\delta 1 \alpha$ and $\tau \grave{\alpha}$ kovvò óvó $\mu \alpha \tau \alpha$ or $\dot{\rho} \eta \mu \alpha \tau \alpha$ (see section 4 below). Orpheus who clearly saw the philosophical truth, for some reason decided not to reveal it to the polloi and therefore expressed

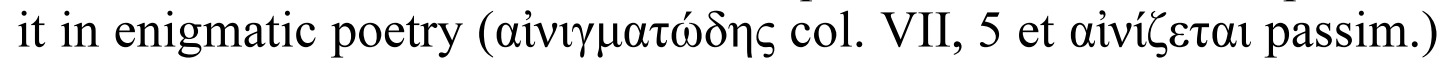
Presumably, he did the same when he established the sacred rites. Instead of using plain words of the common language - the kouvò óvó $\mu \alpha \tau \alpha$ - Orpheus covered his message in «idiomatic» or «peculiar» words, $\tau \grave{\alpha}$ i $\delta 1 \alpha$. The «peculiar» words were partly invented by Orpheus himself - these are the divine personal names. In some cases, however, Orpheus used existing words of the current language of his time ${ }^{16}$, but gave them unusual meaning - these

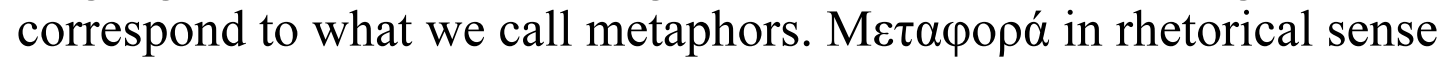
is not attested before Isocrates and Aristotle, both the Derveni author

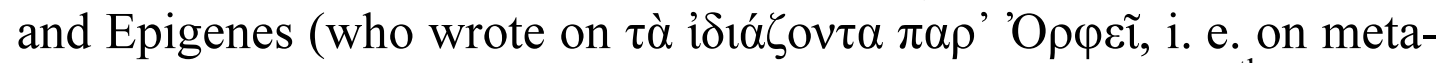
phorical or allegorical expressions) use a more archaic $5^{\text {th }}$ century terminology. ${ }^{17}$ The author of the Derveni Treatise pretends to know

${ }^{14}$ See the quotation from Clement in note 13. Herodorus wrote $\tau \grave{\eta} v$

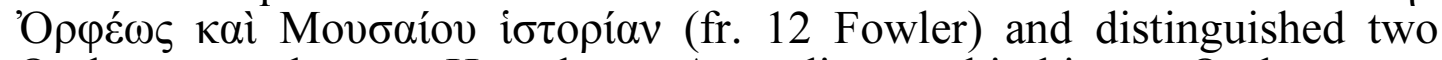
Orpheuses and seven Heracleses. According to this history Orpheus was recommended to Jason by Cheiron (fr. 43 F.), whereas Heracles did not sail with the Argonauts at all (fr. 41 F.). Herodorus knew Anaxagoras' theory of the moon as a «celestial earth» and used it in his sci-fi fiction about Selenites (fr. 21 F.). Can he be the author of Cheiron the astronomer story as well?

${ }_{16}^{15} 60$ A 1; A 2; A 4.6 DK.

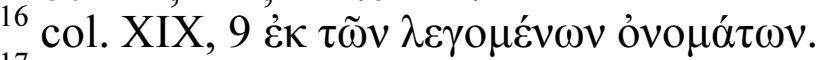

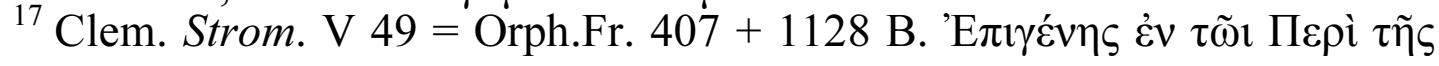


the secret code for the correct reading of this prototext of the human

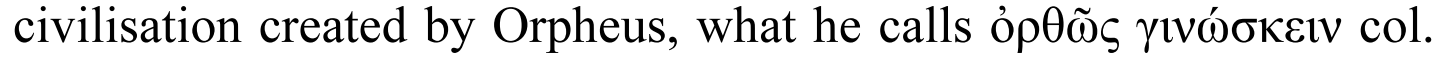

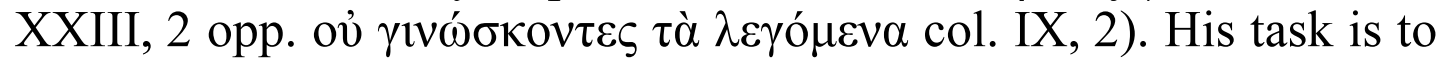
retranslate back the «peculiar expessions into common», $\tau \grave{\alpha}$ í $\delta 1 \alpha$ into

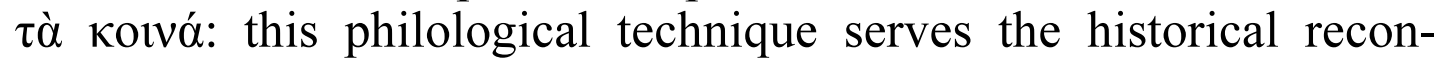
struction of the religious beliefs of the "ancients» and their subsequent transformations. We will call this method a «linguistic archeology». Here is the list of correspondences with «translations» from the Prehistoric Mythopoetic Greek into plain prose, a kind of glossary of the divine names and metaphorical expressions in the theogony of Orpheus:

I $\triangle$ IA ONOMATA to KOINA ( $\triangle$ EГOMENA) ONOMATA (PHMATA)

1. àn $\rho$ from $\alpha i \omega \rho \varepsilon \tilde{\sigma} \sigma \theta \alpha$ col. XVII, 3-4.9

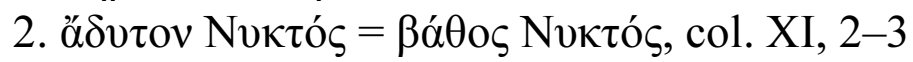

3. $\alpha$ i̊ooiov $=\dddot{\eta} \lambda$ io $\mathrm{col}$. XIII, 9; XVI, 1

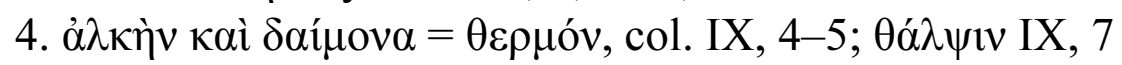

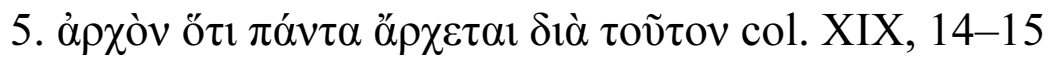

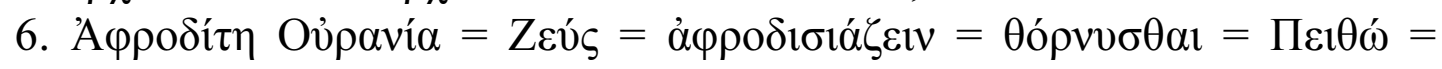
Appovía col. XXI, 5-7

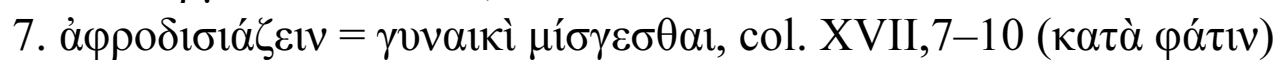

8. А $\chi \varepsilon \lambda \tilde{\omega} 10 \varsigma=\tilde{v} \delta \omega \rho$ col. XXIII, 12

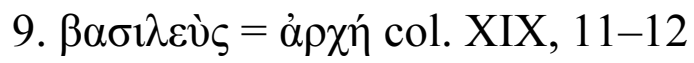

10. Г̃̃ vó $\mu \omega \imath$ col. XXII, 8

11. $\delta \alpha i ́ \mu \omega v$ from $\delta \alpha i ́ \omega$ 'to burn', hence $\pi \tilde{v} \rho$ (= $\ddot{\eta} \lambda$ เos) col. IX, 4-5.13

12. $\Delta \eta \mu \eta \dot{\tau} \tau \rho=\Gamma \tilde{\eta}$ Mí $\tau \eta \rho$ XXII, 10

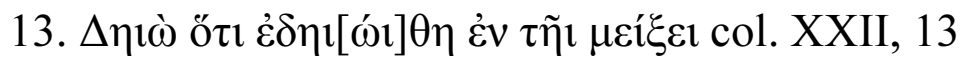

14. $\Delta i ́ \alpha=\delta i \alpha ́$ XIX, 15

15. $\Delta i ́ \alpha=\delta i ́ v \eta$

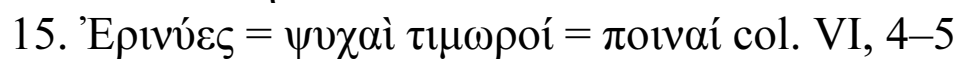

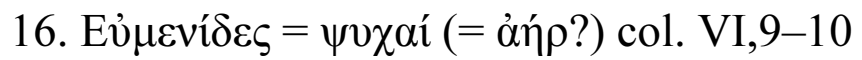

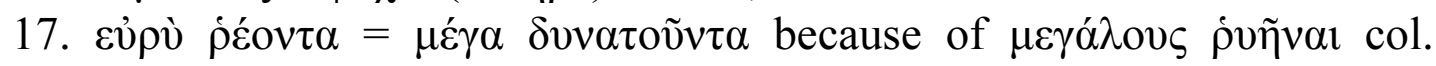
XXIII, 6-10

18. Zzv́ $=$ voṽ $\varsigma$ col. XVI,1 0

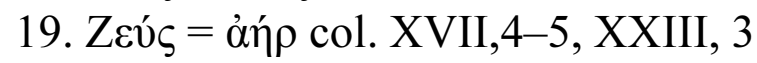

20. $\kappa \varepsilon \varphi \alpha \lambda \eta ́ ~=\grave{\alpha} \rho \chi \eta ́, \mu \varepsilon ́ \sigma \sigma \alpha=\kappa \alpha ́ \tau \omega ~ \varphi \varepsilon \rho o ́ \mu \varepsilon v \alpha \kappa \tau \lambda$. col. XVII, 13-14;

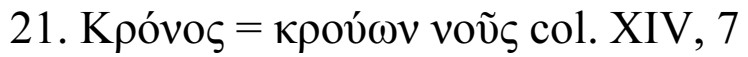

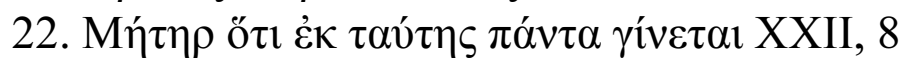

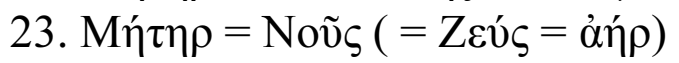

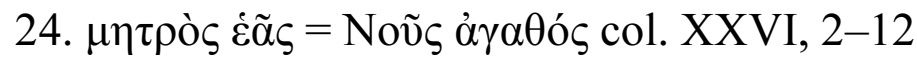

25. Moĩ $\alpha \Delta$ ió $=\pi v \varepsilon \tilde{v} \mu \alpha$ col. XVIII,2; ơń $\rho$ XIX, 3

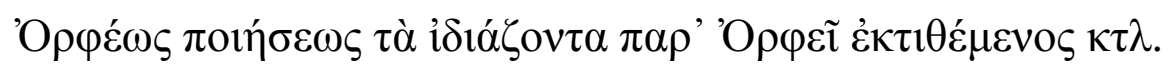


26. Moĩ $\alpha=\varphi \rho o ́ v \eta \sigma ı \varsigma ~ \theta \varepsilon o v ̃ ~(\Delta ı ́ ́ \varsigma)$ col. XVIII, 7 sq.

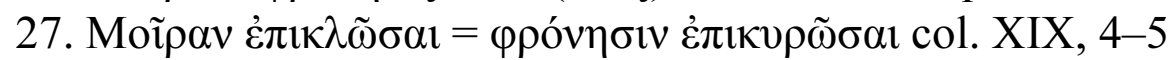

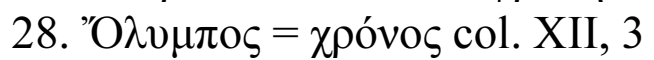

29. Oủpavó $\varsigma=$ ópí́ $\omega v(\chi \omega \rho i ́ \zeta \omega v)=v o v ̃ \varsigma(?)$ col. XIV, 12

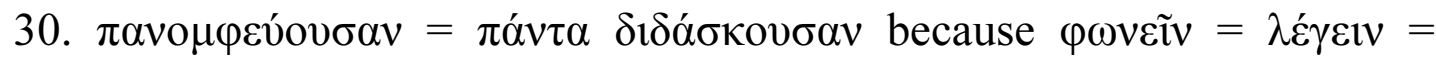
$\delta 1 \delta \alpha ́ \sigma \kappa \varepsilon ı v$ col. X, 9-10

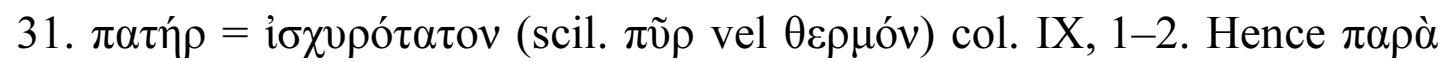

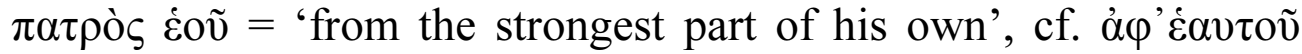
$\mathrm{XIV}, 2$

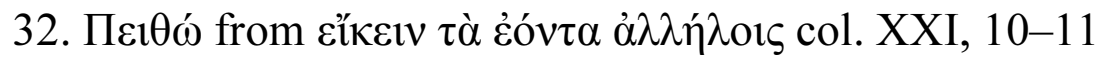

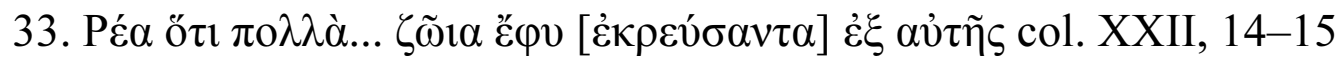

34. $\chi \rho \tilde{\eta} \sigma \alpha l=\dot{\alpha} \rho \kappa \varepsilon ́ \sigma \alpha l$ col. XI, 5

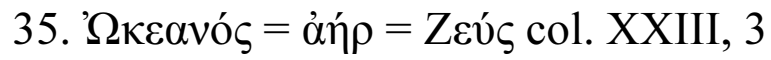

Equations of divine names

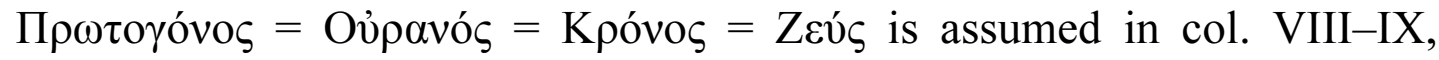
XIII-XVI

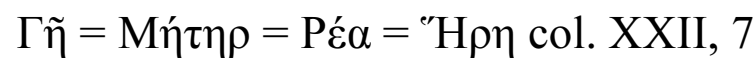

The restricted use of etymology confirms our impression that the author is not an allegorist in the usual sense. He uses etymologies and some of them are important for his argument, but more often he looks not for a phonetic correspondence of the explanatory kolvóv with the "iovov, but for a functional equivalence. Thus, $\alpha$ idooiov is equated with the Sun because their function is the same: a generative principle. He states explicitly his functionalist thesis as a general principle of nomination in the following two passages.

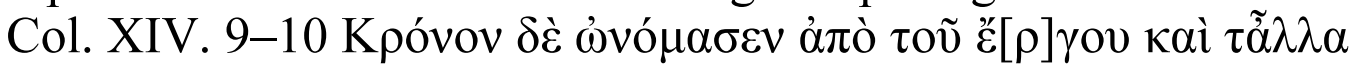

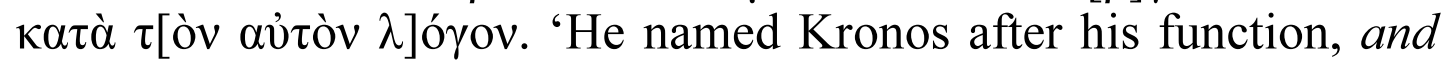
all other things (or gods) by the same principle' (i. e. 'after the function of each thing').

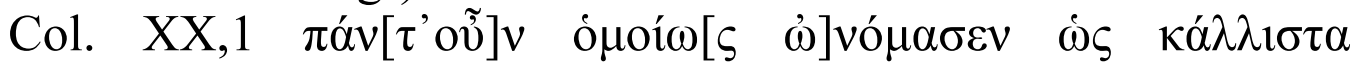
$\grave{\eta}\left[\delta v^{\prime}\right] v \alpha \tau o . .$. 'And so, he named all things (or rather «gave all divine names») in the same way as best as he could'.

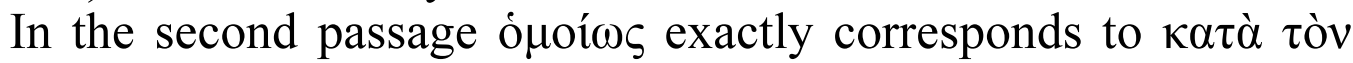

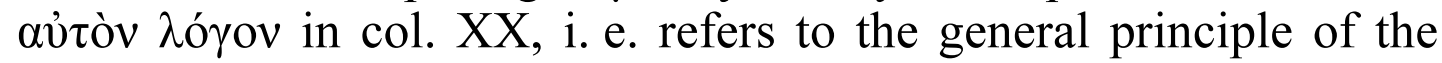
functionalist semantics (as we will call it) and the theory of

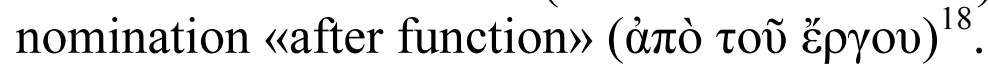

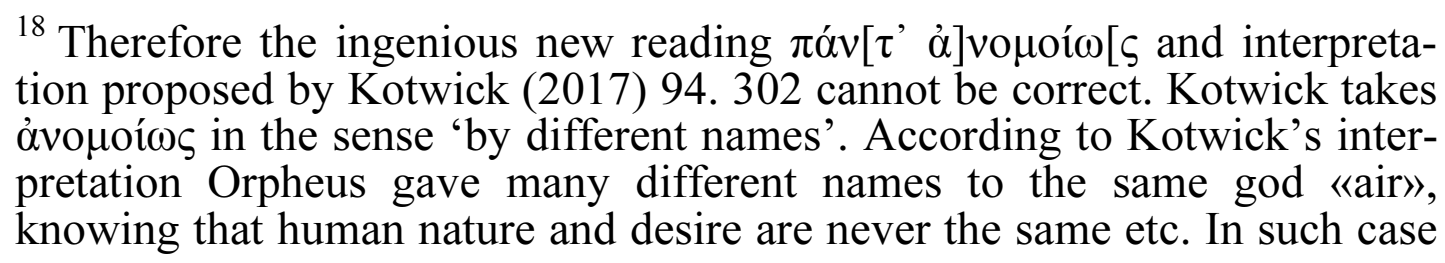


The allegorical method based on the functionalist semantics rather than on the lexical affinity and phonetic assonance of a name with its «original» etymon (paronomasia) can be with equal success used in physical allegoresis, but it should be distinguished from the «classical» etymological allegoresis of the Stoic type. The Stoic allegoresis of mythical names is based on etymology, i. e. on the phonetic similarity between the traditional name and the «real»

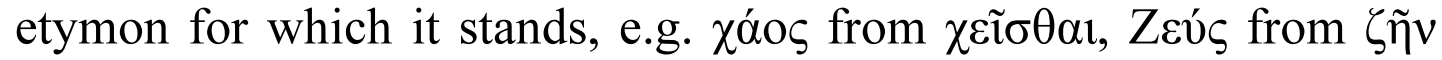

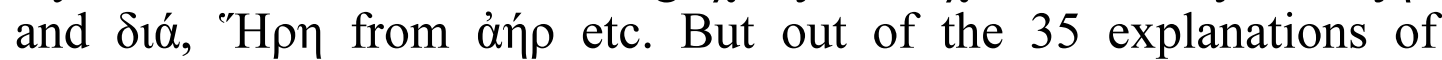
«peculiar» expressions in PDerv (see the «glossary» above) only 10 are based on etymology ${ }^{19}$. This means that more than two thirds are based not on etymology, but on the functionalist semantics

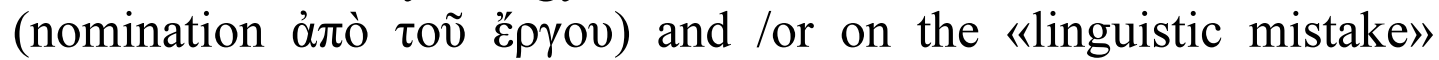

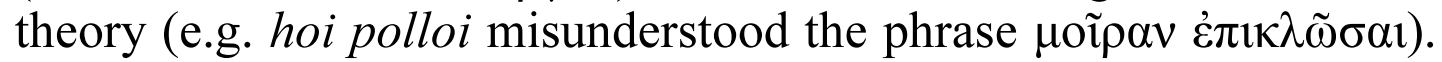
How these two methods relate to the two schools of thought in the philosophy of language known from Plato's Cratylus, i. e. naturalism and conventionalism? Prima facie one is tempted to correlate the etymological method with naturalism and the functionalist semantics with conventionalism. But let us be cautious: out of 35 names only one $(\gamma \tilde{\eta})$ is said to be «by convention» (vó $\mu \omega t)$. The Derveni author does not claim to be a conventionalist and he probably isn't. He seems to believe that when something is named

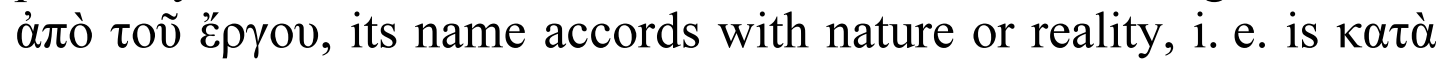
pv́бıv. As we shall see, in col. XX he contrasts Orpheus' «always the same» rule of giving names to things with the human inconstancy and wishfulness in their desires and speeches, and this already looks like like a critique of the conventionalism (for details see Lebedev 2019). The «correct» method of naming is exemplified

Orpheus' attitude towards this variability and instabilty of human behaviour and speech must be positive since he named everything ópı $\sigma \tau \alpha$. But

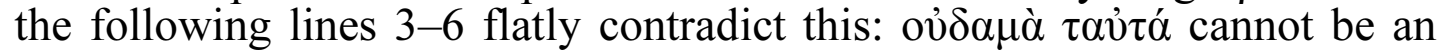
example of $\ddot{\alpha} p \imath \tau \tau \alpha$, this lack of stability and consistency is perceived in negative terms and even attributed to the human $\pi \lambda \varepsilon \sigma v \varepsilon \xi i \alpha$ and $\alpha \mu \alpha \theta i \alpha$. The Derveni author contrasts the human inconstancy and capricious wishfulness with Orpheus' methodic exactness in giving the names to things and gods always in accordance with the same «best» principle, i. e. «after function». This principle is exemplified in the lines 7-16 that follow after the moralistic tirade: Meter was named from «giving birth» to all, Deo

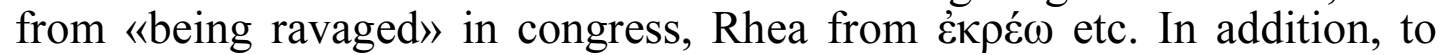
judge by the plate 22 in KPT three letters after $\pi \alpha v$ fill the gap better than two.

${ }^{19} \# 1,5,11,12,13,14,21,29,33$ in the list above. 
in the same col. XX by the names of the gods derived from their «function» or their deeds.

The distinction of the name and the function of a thing it denotes

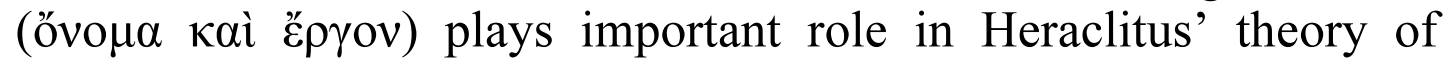
naming, but unlike the Derveni author Heraclitus emphasises that ordinary names (i. e. koina, legomena in PDerveni) contradict their function. ${ }^{20}$ Functionalism and utilitarianism are related schools of thought. The functionalism in semantics points to a thinker with a general utilitarian outlook: the value of something is determined only by its use, and hence by its usefulness ( $\tau$ ò $ڤ \varphi \varepsilon ́ \lambda \imath \mu o v)$.

By translating $\chi \rho \tilde{\eta} \sigma \alpha 1$ as $\dot{\alpha} \rho \kappa \varepsilon \dot{\delta} \sigma \alpha 1$ the author eliminates mantics and oracles $(\chi \rho \eta \sigma \mu o i)$ as nonsense; the humorous interpretation of the oracular cave of the Night as a nighttime (i. e. as non-entity) in col. VII follows the same anti-mantic lines. By explaining the mythical Oúpavó entity $)^{21}$ he intentionally deconstructs the divine world. The Hymn to Zeus is a godsend for this purpose. Since Zeus is everything, and

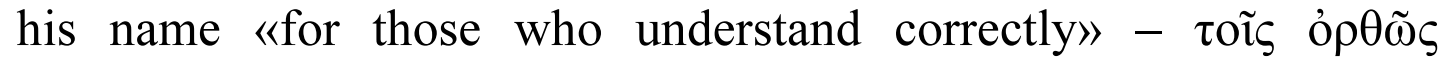

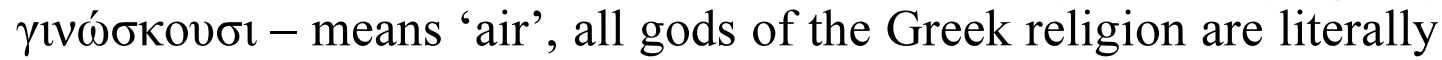
dissolved in the air. Air is the common referential substrate of all conventional divine names (cf. Heraclit. 43L/B 67). Hence the equations of the divine names in DervT are to be taken not as examples of mystical syncretism or sophisticated philosophical theology, but as intentional deconstruction of divine personalities. The Succession myth, according to the Derveni author, is nonsense since all its participants - Protogonos, Night, Ouranos, Kronos, Zeus are different names of the air, or of its constituents (hot particles), or of the processes such as the separation of the sun. The translation of Olympos as 'time' is connected with the reduction of gods to processes: the 'gods' exist not on Olympus, but 'in time'; they are fluctuations of the air. The conceptual frame of such etymologies is Heraclitus' theory of the Universal flux and change of all things that Plato associates with the tandem Protagoras-Heraclitus.

It follows that not only the mysteries, but also Greek religion as a whole is a result of misunderstanding, a kind of a linguistic

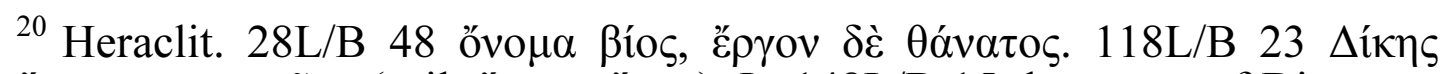
ővo $\mu \alpha$ opp. $\tau \alpha \tilde{\tau} \tau \alpha$ (scil. ővo $\mu \alpha$ है $\rho \gamma \alpha$ ). In 148L/B 15 the ergon of Dionysos

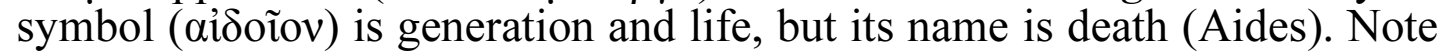
that unlike the Derveni author Heraclitus regarded separate names of ordinary language as «syllables» of original natural names, i. e. of integrated pairs of opposite like life-death, for details see Lebedev $2017_{1}$.

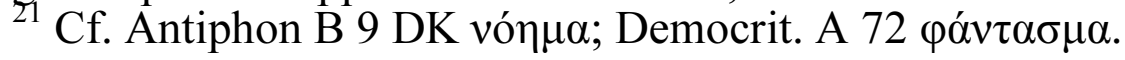


mistake similar to a «disease of language». The worship of the traditional gods is a result of a misreading of the Proto-text by the ignorant polloi. The referential meaning of the divine names is different from the meaning intended by the polloi. When they hear the name of Zeus they imagine the wellknown anthropomorphic

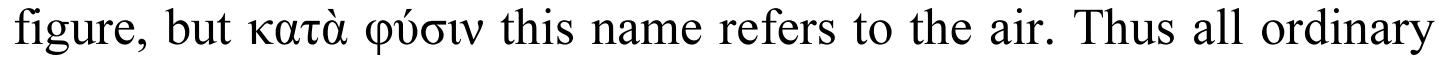
Greeks are fools: they do not realize that in fact they worship different forms of air, i. e. natural phenomena. A theory of the original linguistic mistake of mortals that leads to even more catastrophic consequences, i. e. to the origin of the phenomenal world of plurality, is attested in Parmenides (B 8.53 ) (Lebedev 20172: 510513). The Derveni author borrowed it from another source that he cites in col. IV. The theory of the linguistic mistake of mortals was apparently suggested to the Derveni author by Heraclitus together with Heraclitus' theory of the ambiguity of the cosmic logos (Lebedev 2014: 61-69).

Was Orpheus' ambiguity according to the Derveni author intentional? The answer must be «yes», for this is explicitly stated in col. VII. It follows that Orpheus deceived the crowd. Why? We do not find an explicit answer to this question in the extant parts of the text. But given the sophistic character of the Derveni treatise, it is natural to suppose that Orpheus, according to our author, did it for the very same reason as the бoфòs àví in the Critias' Sisyphus, fr.

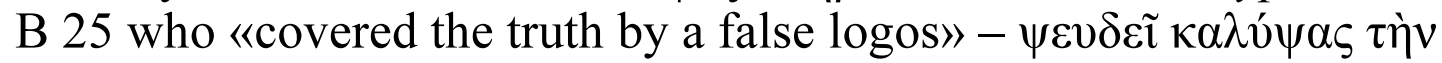
$\dot{\alpha} \lambda \eta \dot{\eta} \theta \varepsilon 1 \alpha \nu \lambda \operatorname{ó}_{\gamma}(1.26)$, so that the crowd would obey the laws by fear of the omniscient gods. The natural phenomena that were mistaken for anthropomorphic gods according to Sisyphus - the Revolution of the Heavens (The Vortex of Air), the thunder and lightning, the starry Sky, the ö $\mu \beta \rho o$ are very similar to those in the DervT. This means that, according to the Derveni author, Orpheus intended the «surface» meaning of his poetry for the ignorant polloi, and the hidden meaning for a few, i. e. for philosophers (who were called Sophists in 5th century Athens) and their disciples. Religion and science were both invented and transmitted to posterity by Orpheus in his poetry.

From the Derveni author's point of view the "common names» (Kovvò óvó $\mu \alpha \tau \alpha$ ) existed already at the time of Orpheus, but the «peculiar names» (i $i \delta \alpha)$ were invented by Orpheus. In other

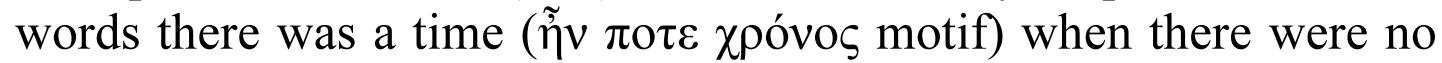

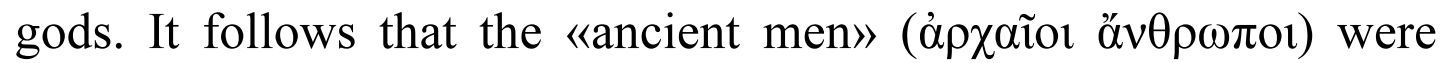
natural atheists who worshipped only the Sun, the Moon and the 


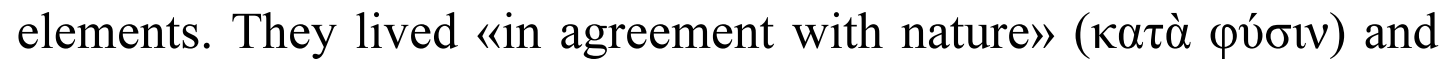

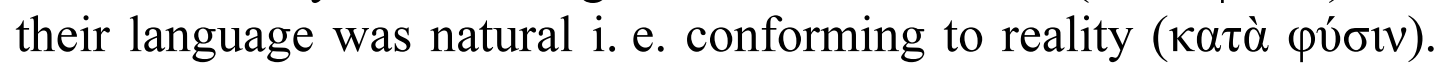
In his exegesis the Derveni author therefore follows «the ancients». The distinction of the «first» and «secondary» names plays important role in Plato's Cratylus ${ }^{22}$. Plato's theory is significantly different from that of PDerv since in it the «first» mimetic names are rather structural elementary units from which secondary names are built and they are not identical with the common names of the current usage ( $\tau$ ò Kovvó). Still there are some points of convergence, too. In Plato the first names imitate the essence of things ${ }^{23}$, and in PDerv the common names refer to real things ( $\pi \varepsilon \rho \mathrm{i} \tau \tilde{\omega} \nu \pi \rho \alpha \gamma \mu \alpha \dot{\tau} \omega \nu$ XIII,7). All or most divine names in the Cratylus must be secondary, too, and all of them, as in PDerv, require a special decoding. Although it is not stated explicitly that the extant divine names are corrupted or distorted, this is implied by the reconstruction of their original «integral» forms that have been forgotten by the polloi. Etymologising is a kind of recollection (anamnesis). The Derveni author's explanation of the traditional Greek mythology displays a striking similarity with Max Müller's view of all ancient mythology as a «disease of language»: «Mythology, Lebedev 2014

which was the bane of the ancient world, is in truth a disease of language. A mythe means a word, but a word which, from being a name or an attribute, has been allowed to assume a more substantial existence. Most of the Greek, the Roman, the Indian and other heathen gods are nothing but poetical names, which were gradually allowed to assume a divine personality never contemplated by their original inventors» (Müller 1885: 11).

There are reasons to suspect that the DervT is not only a sophistic Kulturgeschichte with an atheistic message addressed to the ignorant polloi, but also a polemical work, a pamphlet, addressed to certain philosophical opponents. In Plato's Cratylus «Orpheus» is quoted now as a witness to the Pythagorean soma/sema doctrine, now as supporting the Heracliteans, i. e. from Plato's perspective the Ionian naturalists, the supporters of the doctrine of Universal Flux (oi $\dot{\rho} \varepsilon$ ov $\tau \varepsilon \varsigma$ ). Most probably Plato parodies two conflicting interpretations of Orpheus at the time of Socrates. The «Pythagorean» and the «Ionian» versions of «Orpheus» reflect the ideological

${ }_{23}^{22}$ See the lists in Rijlaarsdam 1978: 163-164.136 ff.,257 ff., $271 \mathrm{ff} ., 295 \mathrm{ff}$.

${ }^{23}$ On this see Baxter 1992: 62 ff., 76 ff., 167 ff.; Barney 2001: 83-98; Ademollo 2011: 278-280. 
conflict between the Sophistic Enlightenment and the religious conservatives: the dispute between Anaxagoras and Lampon, the psephisma of Diopeithes against the natural philosophers are wellknown and typical examples. In the Dissoi logoi the "Anaxagoreans

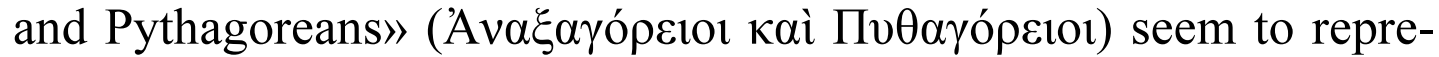
sent two main schools on the philosophical scene circa 400 B.C. with conflicting views ${ }^{24}$. The «Pythagoreans» claimed that their religious philosophy is sanctioned by the authority of the most ancient theologos Orpheus ${ }^{25}$. The simplest way to refute their claims was to prove that the Orphic Theogony is a fake and that the poet Orpheus never existed, as was done by Aristotle (Aristotle fr. 26-27 Gigon), presumably in his polemics against the Old Academy. The Derveni author chose another method which again testifies to his inventivness and wit: he accepts (or pretends to accept) the historicity of Orpheus and the authenticity of the Orphic Theogony, and then proves that Orpheus in fact was an Anaxagorean himself, and

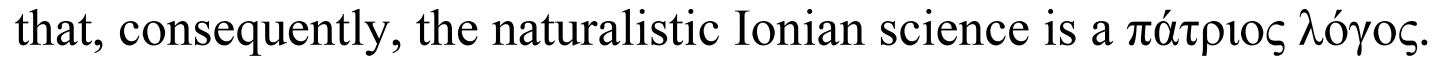

The Derveni author is neither "Orphic» nor a religious specialist. After Tsantsanoglou (1997) it has often been inferred

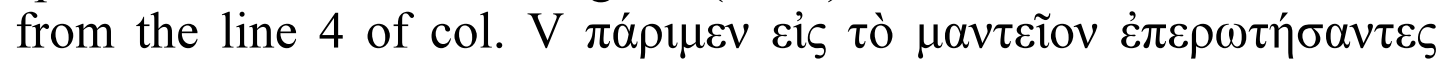
'we enter an oracle in order to ask a question' that the writer was a mantis or a religious specialist himself ${ }^{26}$, but this is contradicted by

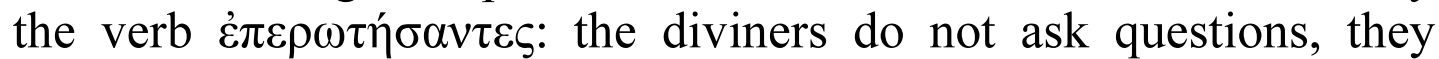

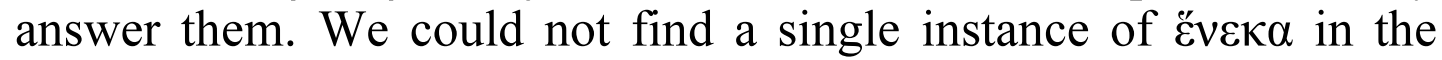
sense of 'for the sake of others' by various whole-corpus proximity

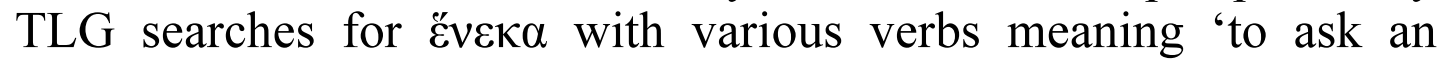
oracle' and nouns meaning 'oracular response'. In all found

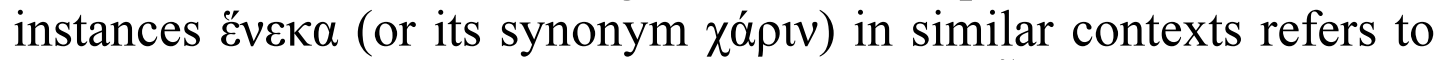
the purpose of consulting an oracle (syn. $\pi \varepsilon \rho \hat{~} \tilde{\omega} v$ ), but never means

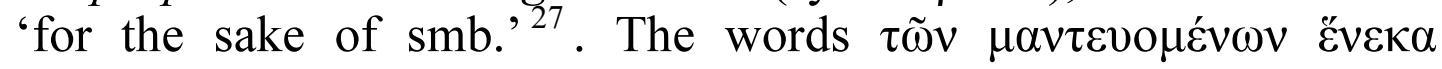

${ }^{24}$ Dialexeis 6.8; DK II,414,13. This was seen by S. Luria (Luria 1928: 225; 1970: 386).

${ }_{25}^{25}$ Orpheus $\mu \alpha \rho \tau v \rho \varepsilon \tilde{~ i n ~ P h i l o l a u s ~ B ~} 14$.

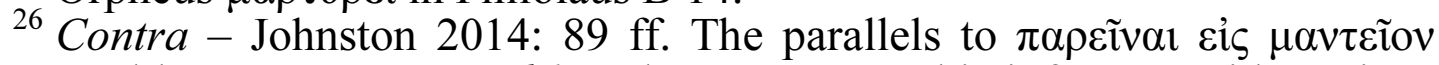
quoted by Kouremenos, ad loc. do not support this inference, either, since both in Herodotus and Euripides the phrase is applied not to Pythia, but to ordinary consultants.

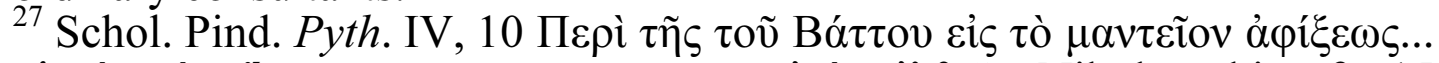

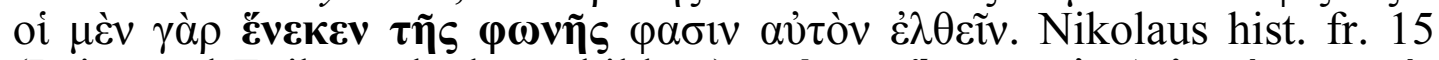

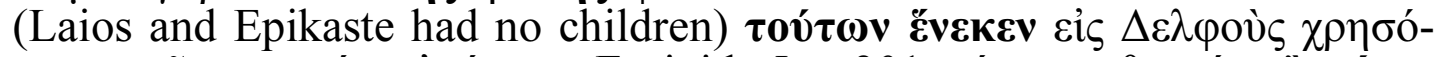

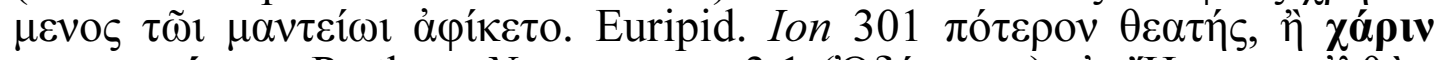

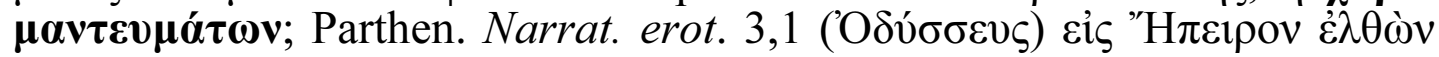

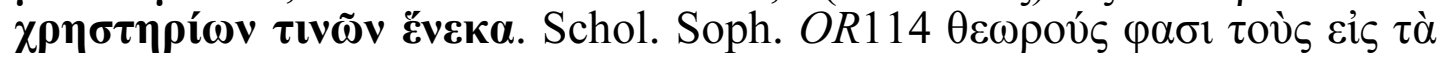


therefore mean 'for the sake of prophecies', and not 'for the sake of inquirers ${ }^{28}$. The «we» in the pluralis $\pi \alpha$ ó $\mu \varepsilon v$ refers not to a certain group or a corporation, but to general human habits. Greek philosophers, especially moralists, use we when they speak about common habits, practices or experience of men in general. Heraclitus fr.

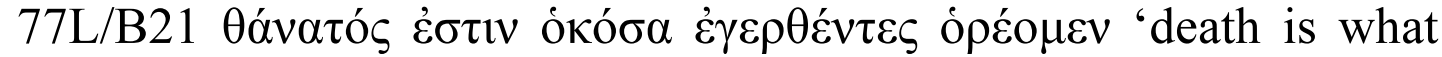

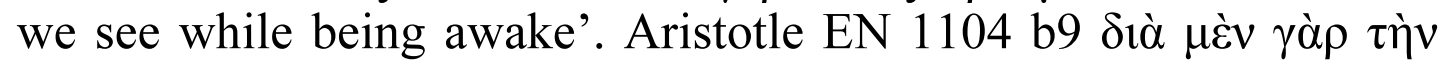

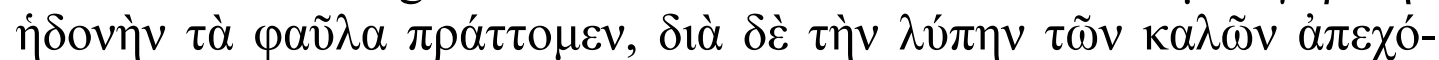
$\mu \varepsilon \theta \alpha$. Examples can be multiplied. In the last case the speaker probably does not even include himself into «we». It would be preposterous to infer from this text that Aristotle indulged in pleasures and abstained from the noble behaviour. The sentence under discussion in. col. V may well be a rhetorical interrogation (with expected negative answer) in a series of rhetorical questions, e.g.

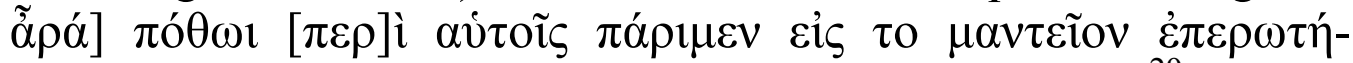

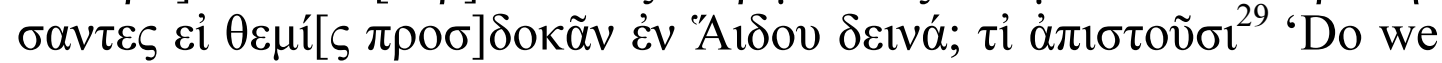
by regret [or «disquietude»] about ourselves ever consult an oracle for the sake of prophecies, in order to ask whether it is righteous to expect the horrors in Hades? Why they do not believe?'

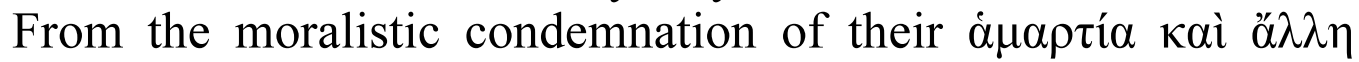

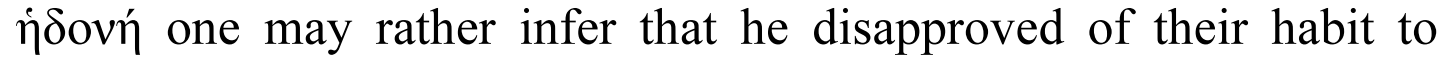
consult oracles. The Hippocratic author of De Diaeta admits (probably influenced by Heraclitus) that the dreams may have a prognostic value, but discourages his reader to go to the interpreters of dreams because they often commit a mistake ( $\dot{\alpha} \mu \alpha \rho \tau i ́ \alpha)$. Instead, he advises the reader to interpret himself the signs of health and disease in their dreams following his naturalistic guidelines (Hippocr. De Diaeta, I, 87-88).

On the ground of these observations we can draw the following portrait of the Derveni author: a Pre-Platonic Sophist and polymath,

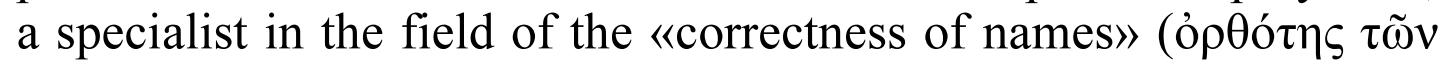
óvouó $\tau \omega v)$ and an adept of functionalist semantics in his theory of naming (which is theoretically connected with his general utilitarianism), versed in rhetorics and physical science in which he follows Archelaus' version of Anaxagorean physics, with a profound interest in the Kulturgeschichte and the origin of religion and language; a supporter of the naturalistic pantheism that may well have been

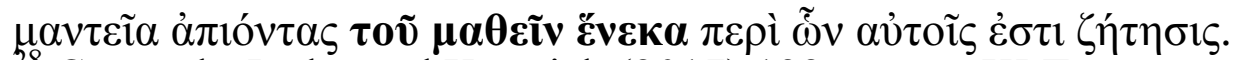

${ }_{28}^{28}$ Correctly Janko and Kotwick (2017) 132, contra KPT.

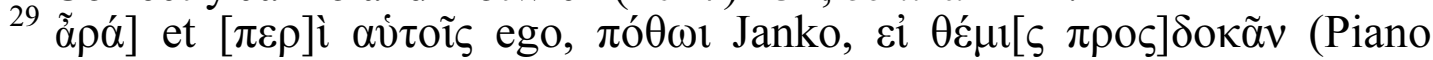
2016: 13). 


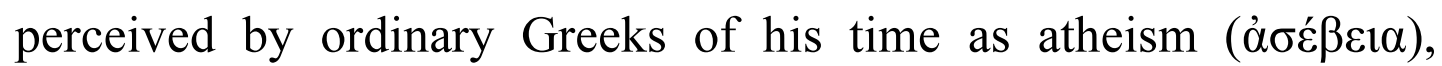
heavily influenced by Heraclitus, especially by Heraclitus' allegoresis of mythical names and criticism of popular religion; a rationalist of the utilitarian stamp; he wrote his work with a polemical purpose against the Orpheotelestai, manteis and religious conservatives as well as against the uneducated pollo $i$ who support them. It is obvious that we are dealing with a thinker of great originality, amazing learning and inexhaustible inventiveness. He speaks with authority as a recognised Master of Truth. It is very unlikely that he was a marginal figure and left no trace in Greek philosophy and intellectual life $\mathrm{e}^{30}$; it is also unlikely that his name has not been preserved in the tradition. On the contrary, we have good reasons to suppose that he is one of the intellectual celebrities of the Greek Sophistic Enlightenment; moreover, the work we call the Derveni treatise may have been scandalously famous.

\section{(3) Attribution of the Derveni treatise to Prodicus of Ceos. Testimonia.}

No palpable connections with Gorgias and Hippias. Critias' theory of the origin of religion as invention of a sophos aner of ancient times displays a typological similarity with PDerv, but the smart impostor in this case is Sisyphus, not Orpheus. The divulgation of Eleusinian mysteries is insufficient for an ascription to Diagoras of Melos; and besides, our author is a professional Sophist, whereas Diagoras was a dithyrambic poet about whose «atheistic» doctrines nothing whatsoever is known ${ }^{31}$. Protagoras' works Пepì

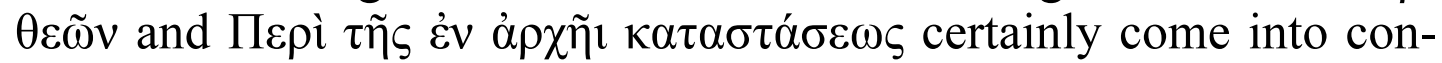
sideration and fit the subject of the Derveni treatise, but the scarcity of references to Protagoras in the supposed reflexes of DervT in later authors can hardly be accidental ${ }^{32}$. Of all Greek Sophists it is Prodicus of Ceos who fits the composite image of the author immediately and exactly. Prodicus was the leading expert in the ópótns

\footnotetext{
${ }^{30}$ This possibility is rightly rejected by W. Burkert, o.c. Contra Kouremenos in KPT 2006: 59.

${ }_{31}$ Contra Janko 1997; 2001, etc. Persuasively criticised by Betegh 2004: 373-380 and Winiarczyk 2016: 117-126. We add something on this subject in Lebedev 2019, sec. VII and we refute ibidem the unfortunate hypothesis of Luc Brisson on the Stoic origin of PDerv.

32 Protagoras is cited nominatim together with "Orpheus» and Heraclitus in

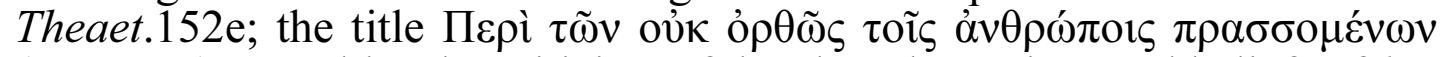
(DL 9.55) resembles the criticism of the absurd practices and beliefs of hoi polloi in PDerv.
} 


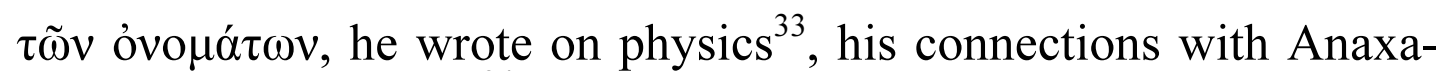
goras are well attested ${ }^{34}$, and his reputation of an atheist was second to none ${ }^{35}$ : «This man has been corrupted either by a book or by Prodicus $>{ }^{36}$. After the trial of Anaxagoras and the psephisma of Diopeithes (432 BC) any Anaxagoreios in Athens may have looked suspicious to the conservative public ${ }^{37}$. His name is regularly included in the lists of atheists and it seems that he was a genuine philosophical atheist of the Protagorean («humanist») extraction, but hardly as scandalous and iconoclastic as Diagoras in the anecdotal tradition. In Plato's Protagoras 315bc the description of Prodicus in Callias' house starts with a humorous quotation from Homer's

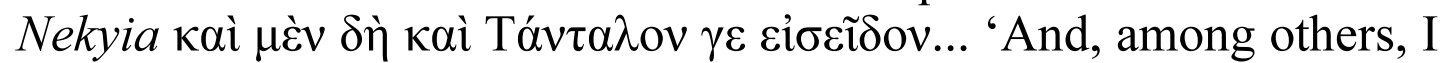
have noticed there Tantalos as well...' In a very important and underestimated article Willink has persuasively refuted the old interpretation (the sobriquet allegedly means «suffering grievous pains» and alludes to the poor condition of Prodicus' health) ${ }^{38}$ and explained it as a mythical paradigm of a «hubristic audacity» of a «cosmological blasphemer» (Willink 1983: $31 \mathrm{ff}$.) like that of the

${ }^{33}$ T 61-66 Mayhew. Note that Prodicus' «physics» pays attention to etymology and the «correctness of names». Galen (T 64-66 M.) rebukes Prodicus for his deviation from the common usage and "innovations» in

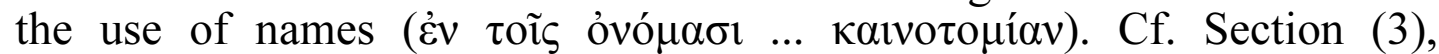
testimonium (T14) below. According to Aulus Gellius, XV,20,4 Euripides was a pupil of Anaxagoras and Prodicus.

${ }^{34}$ Aeschines Socr. ap Athen.V. 62. $220 \mathrm{a}-\mathrm{b}=$ Prodic. T30 $\mathrm{M}=80 \mathrm{~A}$ 4b. Aeschines in his «Callias» mocks Prodicus and Anaxagoras as «sophists» and immoral teachers corrupting the young. It seems that Aeschines readresses to Prodicus and Anaxagoras the accusations of atheism and corruption of the young raised against Socrates.

${ }^{35}$ See first of all: Henrichs 1975: 94-123, on Prodicus $107 \mathrm{ff}$ (reedition of Philodem. PHerc 1428); Henrichs 1976: 15-21; also very important is Willink 1983: 25-27; Scholten (2003) 132 ff.; Mayhew 2013: XVII, 91; Burkert 1985: 313-315. See also Roubekas 2016: 39-42. Reservations about Prodicus' "atheism» have been expressed by Winiarczyk 2016: 66 and Sedley 2013: 141, but they ignore the «Tantalos» paradigm and the important work of Willink (1983). Prodicus did not start to be regarded as atheist by the time of Cicero, he was nicknamed Tantalos (= godless hybristes) already by his contemporaries.

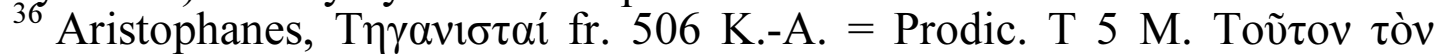

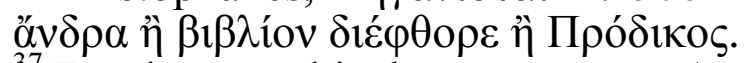

${ }^{37}$ For doxographical testimonia on Anaxagoras' «atheism» from papyri see the important publication of Christian Vassallo in this volume (2018/2019). ${ }^{38}$ e.g. Guthrie 1969: 274. As Willink (p. 30) retorts: «there is no evidence at all to suggest that Prodikos - an itinerant, politically active, long-lived and loud-voiced sophist - was (already in his thirties) a chronic invalid». 
meteorosophistai satirised in Aristophanes' Clouds with Prodicus as their prince and arch-sophist.

The texts of Themistius and Aristophanes cited below leave no doubt that he discussed in his works «the rituals of Orpheus»

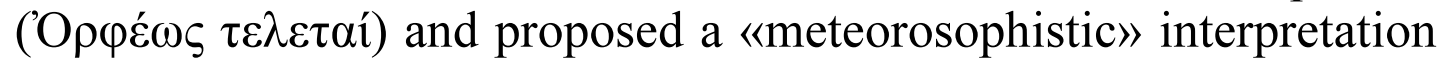
of the Orphic Theogony. Prodicus is the common source of the passages from Themistius, Aristophanes (Clouds and Birds), Plato's Cratylus, Euripides' Bacchae and other testimonia discussed below.

Testimonia (1) - (19) supporting the attribution of PDerv to Prodicus of Ceos

(T1). Plato. Prodicus has been rightly recognised as an important Sophistic source of Plato' Cratylus ${ }^{39}$. His fifty-drachmas lecture «on

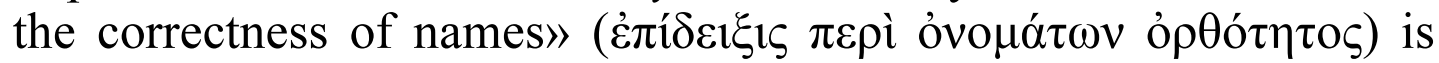
explicitly cited as a classic of the genre (the only one!) in the

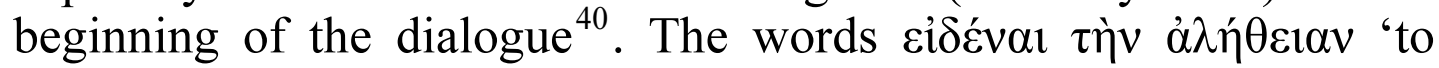
know the truth' (Crat. 384b5) alluding to Prodicus may be com-

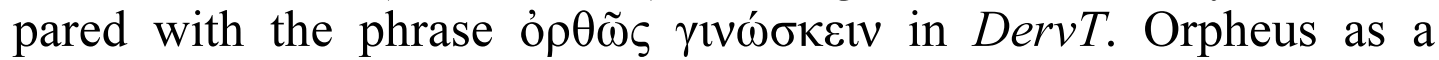
Heraclitean and Anaxagorean philosopher and onomatothetes ap-

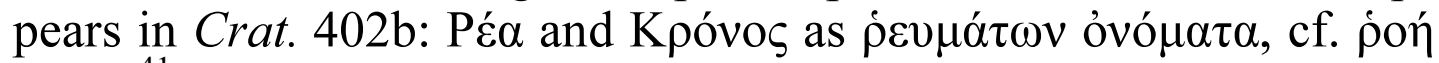
$402 \mathrm{a} 9^{41}$. We may compare this passage with PDerv col. XXII, 13-

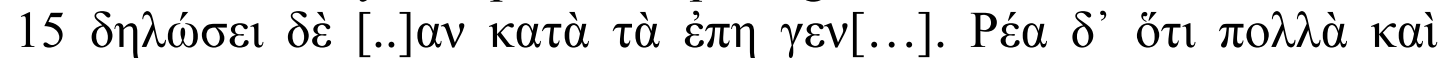

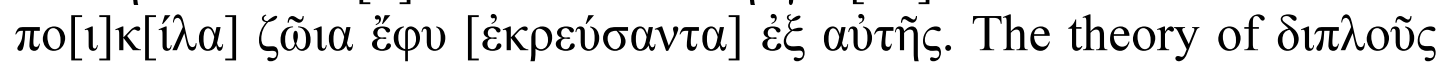

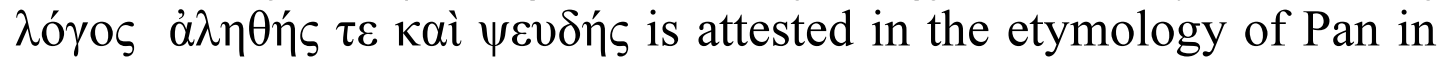
Cratyl. 408c. The $\psi \varepsilon \tilde{v} \delta \mathrm{o} \varsigma$ part of it belongs to $\pi \mathrm{o} \lambda \lambda \mathrm{oi}$ and consists of

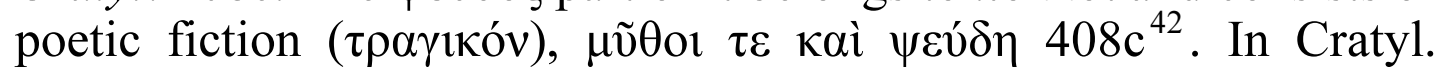

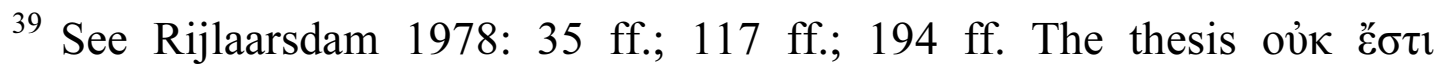

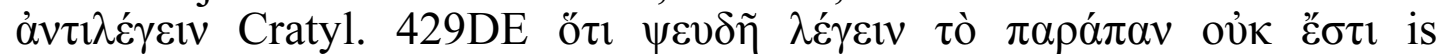
explicitly ascribed to Prodicus by Didymus the Blind, see Prodicus fr. 60 Mayhew (with comm. pp.153-159); Binder, Liesenborghs 1976: 453-462.

${ }^{40}$ Crat. $384 \mathrm{~b}=$ Prodic. T42 M.

${ }^{41}$ Mansfeld's (1983) identification of Plato's source as Hippias cannot be correct since: Hippias is the least philosophical of all Sophists; the relativist theory of flux and sophisticated epistemology are a priori unlikely for him; in the parallel passages Theaet. 152e; 160d Protagoras, and not Hippias is mentioned. Protagoras was never associated with Hippias, but often with his disciple Prodicus. Mansfeld, however, rightly postulates a Sophictic source for the Heraclitizing passages in Cratylus and Theaetetus. This source is most probably Prodicus and/or Protagoras himself who quoted Heraclitus with approval of his criticism of popular religion.

${ }^{42}$ In our edition of Heraclitus (Lebedev 2014: 22) we identify the source of Plato with Heraclitus and include the passage $408 \mathrm{c} 2$ oĩ $\sigma \theta \alpha$ ő $\tau 1 ~ \lambda o ́ \gamma o \varsigma$

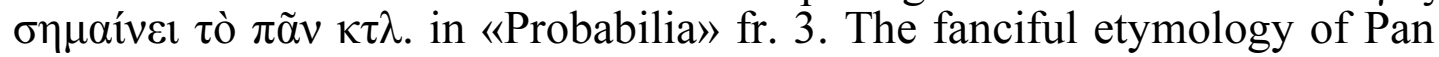
may be Plato's own, but the identification of logos with the Universe is 
409a9 the etymological derivation of the name $\Sigma \varepsilon \lambda \eta \dot{v \eta}$ from $\sigma \varepsilon \dot{\lambda} \alpha \varsigma$ «light» «seems to reveal the more ancient wisdom» similar to the «recent» theory of Anaxagoras that the moon reflects the light of the

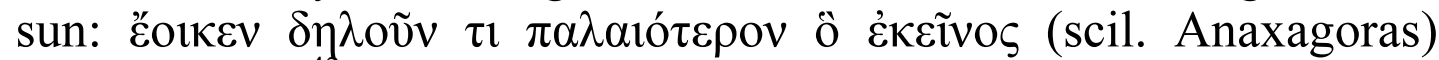
$v \varepsilon \omega \sigma \tau \grave{c} \varepsilon \lambda \varepsilon \gamma \varepsilon v^{4}$. The ancient onomatothetes in this passage is likely to be Orpheus, and so exactly as in DervT the Anaxagorean physiologia is presented as an ancient wisdom that was known to Orpheus and can be discovered in the divine names when they are «correctly understood» ${ }^{44}$. Plato's source must be Prodicus in whose history of culture and religion the case of Selene as a deified «useful thing» must have played important role: on PDerv. col. XXIV, 7-12 see testimonium T3 below. Plato's «accusation» of Anaxagoras in plagiarism from ancient theologians is of course a joke; the playful and ironical tone of this remark is best explained as a parody of Prodicus' extravagant claims about Orpheus' Anaxagorean physics rather than a parody of Anaxagoras himself who never made such claims $^{45}$.

(T2) Euripides. Prodicus T 74 M. (= B 5 DK) is an obvious and recognized by several scholars source of Euripides' Bacchae $274 \mathrm{ff}$. where Demeter is explained as earth $(\gamma \tilde{\eta})$ and Dionysus as wine ${ }^{46}$. According to the Derveni Author, religion and mythology arose from the misreading and misinterpretation of an ancient text of a wise man (Orpheus) by ignorant polloi. A remarkable parallel to this theory is found in Bacchae 286-297. The myth of Dionysus being sewn into and born from Zeus' thigh ( $\left.\mu \eta \rho{ }^{\zeta}\right)$ is explained away as a

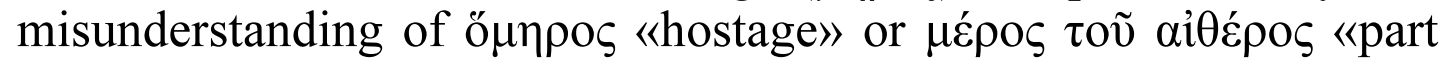

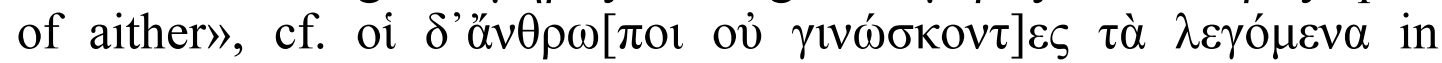
PDerv.col. XVIII,14. The multiple etymologies of the same name that seemed absurd to Euripidean scholars, are typical for the Derveni author and they are typical for Plato's Cratylus as well.

typically Heracltean. It is based on Heraclitus' metaphor of common logos or liber naturae in fr. 2L/B1 and fr. 1L/B50 on which see Lebedev 2017.

${ }_{43}^{43}$ Cf. on this passage Lebedev 1990: 81, n.12.

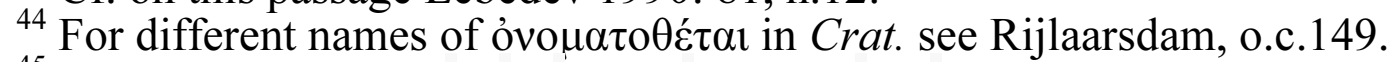

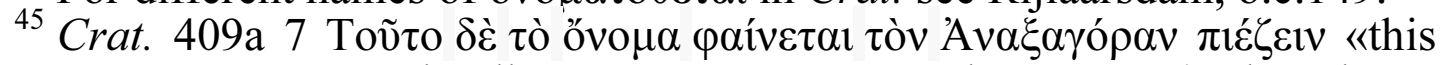
name seems to press hardly upon Anaxagoras». The term $\pi \dot{\varepsilon} \zeta \omega$ here has a connotation «expose» as in legal contexts in which it is associated with

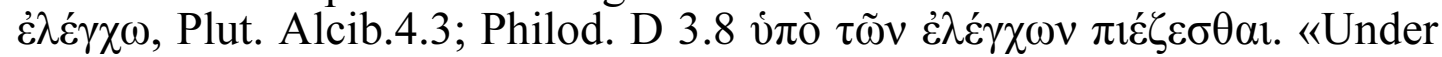
the pressure of evidence» Anaxagoras' plagiarism of ancient wisdom becomes exposed.

${ }^{46}$ Roux (1972) 347; Dodds (1960) 104; Mayhew (2011) 242-244. As early as 1968 Henrichs (ZPE) compared this passage of Euripides with PDerv col. XVIII, Demeter $=$ Ge meter. See also Santamaria (2010). 


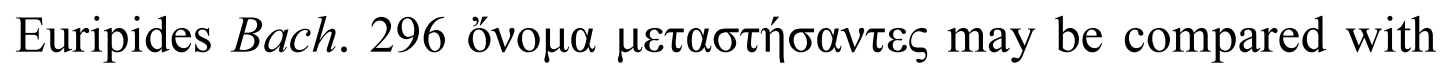

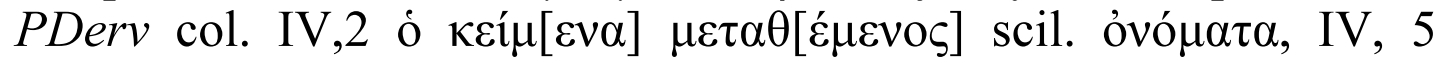

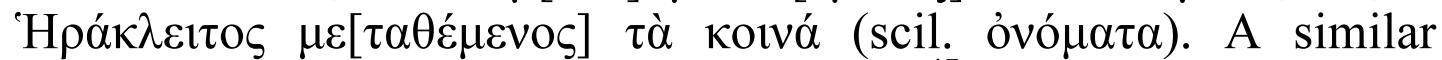
terminology is attested in Plato's Cratylus ${ }^{47}$. Prodicus is the most

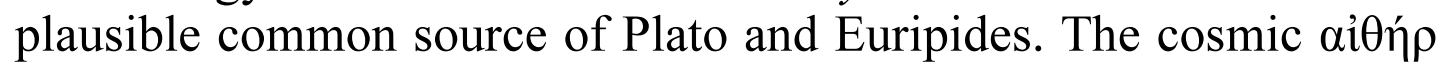
(= air) in Euripides is always a reminiscence of Anaxagoras' cosmology; Zeus and Hera in this passage are apparently allegorised as Air and Earth. In PDerv Zeus is air, and Hera is earth (col. XVII, 4; XXII, 7).

Now we pass to the neglected (as far as we know) evidence of Themistius which is of primary importance for the ascription of the DervT to Prodicus of Ceos.

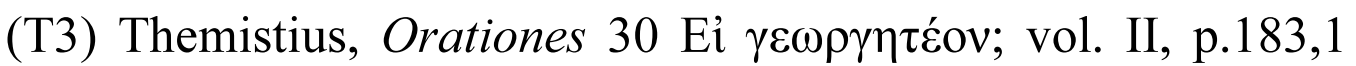

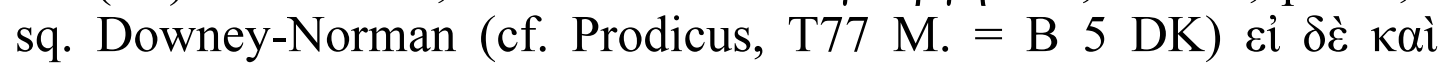

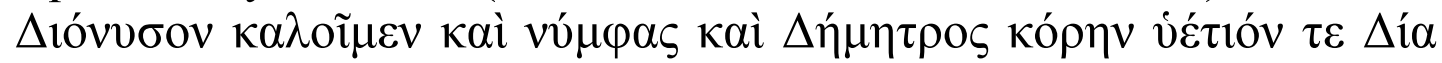

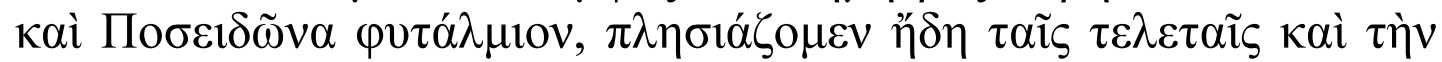

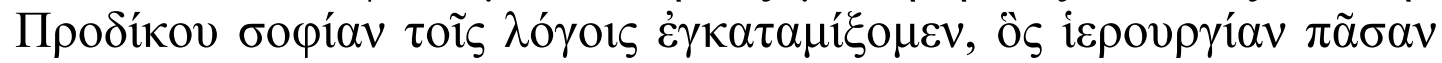

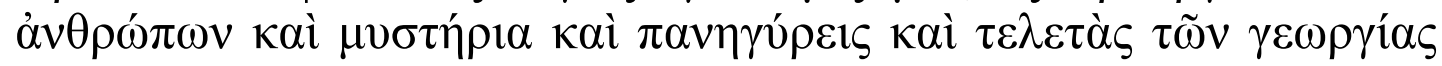

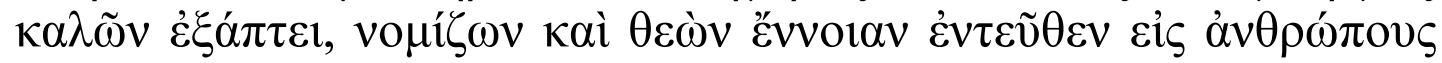

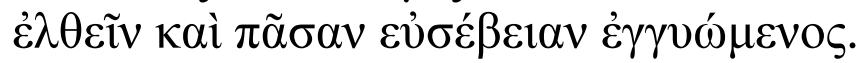

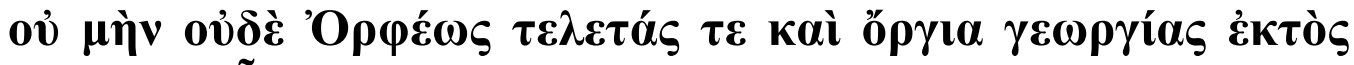

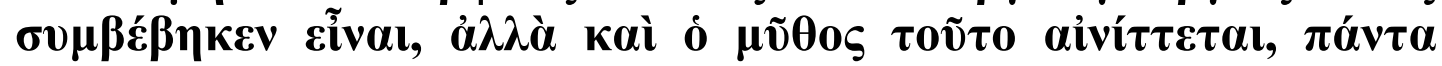

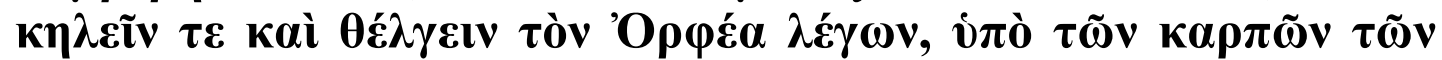

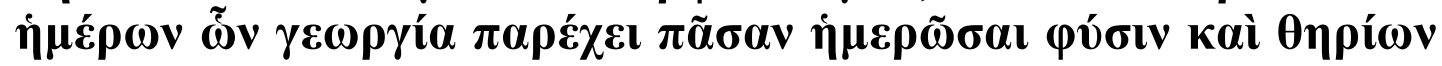

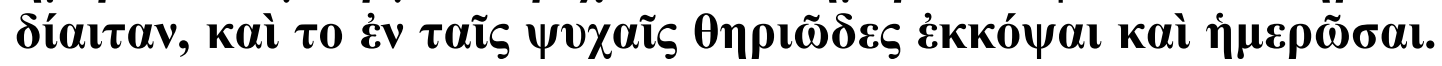

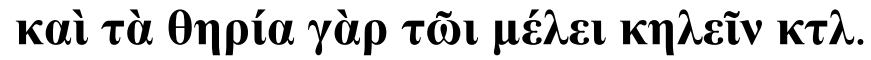

'Let the gods who oversee agriculture be summoned to help me with my oration... For it is from the fruits of agriculture that they receive yearly recompense - drink-offerings, sacrifices, banquets and all the Hours cause to spring up from the earth - and they receive this recompense not only for helping mankind on oratory, but from everything that human beings have from the high. If we should also summon Dionysus, the nymphs, Demeter's daughter [Persephone], the rain-bringing Zeus and nourishing Poseidon, than we shall be within short range of the rites (teletai) and add a dose of Prodicus' wisdom to our eloquence. Prodicus makes all of mankind's religious ceremonies (hierourgia), mysteries, festivals, and rites (teletai) dependent on the blessings of agriculture. He thinks that even the idea (ennoia) of gods came to human beings

${ }^{47}$ Rijlaarsdam, o.c. 147. 
from agriculture and he makes agriculture the guarantee of all piety (eusebeia). Not even the rites (teletai) and mystic ceremonies (orgia) of Orpheus are unconnected with agriculture but the myth about Orpheus also hints to this in enigmatic form, namely that it was through cultivated [i $\mu \dot{\varepsilon} \rho \omega v]$ fruits provided by agriculture that Orpheus tamed [i் $\mu \varepsilon \rho \tilde{\omega} \sigma \alpha l]$ the whole nature and the diaita [= way of life and nutrition] of wild beasts and eradicated and tamed the bestial element in the souls. Indeed, he was believed to enchant wild beasts by his music [melos] conducting all sacrifices and rites in honor of the gods using the fruits of agriculture ${ }^{48}$. After this Themistius presents Orpheus as the greatest culture hero who taught the art of agriculture to all nations of oikumene, this triggered the transition to sedentary life, the rise of civilisation, the emergence of laws and justice etc. DielsKranz print under Prodicus B 5 from Themistius only the words

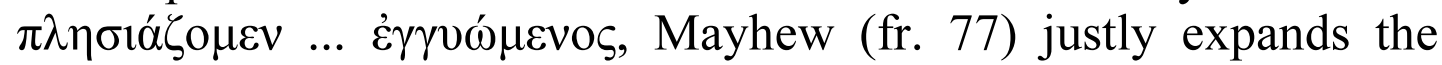

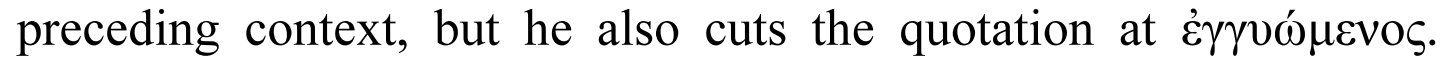
This is based on the assumption that at this point Themistius stops quoting «Prodicus' wisdom», i. e. his agricultural theory of the origin of religion, and adduces a new evidence, the myth of Orpheus the musician, unrelated with Prodicus. But in the preceding text «Prodicus' wisdom» is connected with $\tau \varepsilon \lambda \varepsilon \tau \alpha i$, so in the text set in bold he rather states that what Prodicus explicitly said in his theory of the origin of religion, is also in enigmatic form «hinted by» the

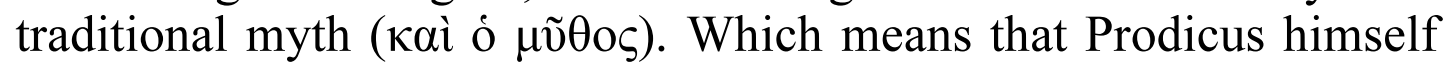
referred to or discussed Orpheus' teletai and Orphic mysteries as providing evidence in support of his theory of religion ${ }^{49}$. The identification of Dionysus with wine, of Demeter with bread, of Poseidon with water are attested for Prodicus by the consensus of Sextus and

${ }^{48}$ Transl. Penella (2000) 185-186 with slight alterations.

${ }^{49}$ Mayhew's scepticism about the authenticity of Themistius' reference to mysteries, orgia, festivals, teletai in Prodicus' work is unjustified. The uniqueness of evidence may call for suspicion in a legal context, but not in the evaluation of historical or literary sources. Themistius' reference is precise and concrete and it is paralleled by a plausible reflex in Plutarch's De daedalibus, see below. Incidentally, Greek agrarian festivals (like those of Dionysos) or mysteries of Demeter provided more abundant and persuasive evidence on the connection between reigion and agriculture than, say, the Orphic Theogony or the poetic myth of Orpheus the Singer. Even on a priori grounds, Prodicus could not miss such opportunity. And this explains why it is Demeter and Dionysus that have a prominent place in Prodicus' theory of religion as cases at point. 
Philodemus (B 5) ${ }^{50}$. The mention of Dionysus and Demeter in combination with mystery cults $(\mu v \sigma \tau \eta \dot{\rho} \rho \alpha)$ and initiations ( $\tau \varepsilon \lambda \varepsilon \tau \alpha i$ ) is sufficient to conclude that Prodicus discussed in his work on the origin of religion the Eleusinian and Orphic (i. e. Bacchic) mysteries. If we accept Henrich's reinterpretation of Philodemus, according to which Prodicus added to «things beneficial for human life»

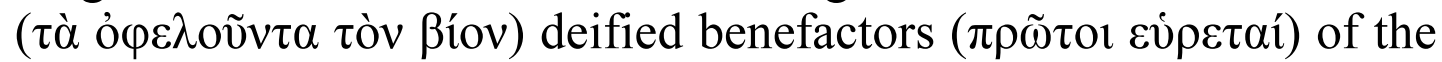
human race, the characterisation of Orpheus as the first agriculturalist in Themistius may also derive from Prodicus ${ }^{51}$.

Prodicus' theory of the origin of religion from agriculture (and other «useful» tekhnai) is directly attested in Pap.Derv. col. XXIV which comments on the Orphic verse about the moon

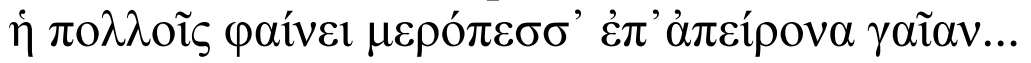

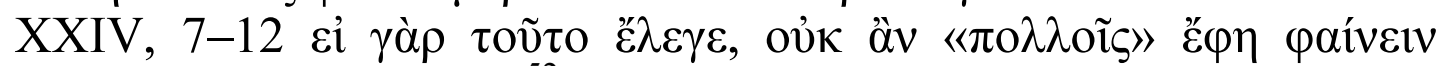

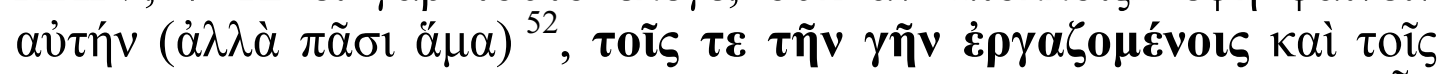

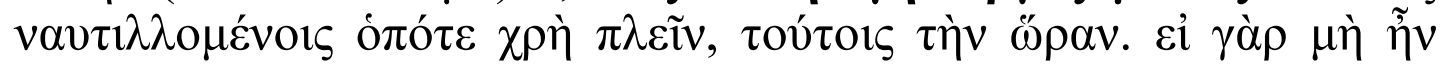

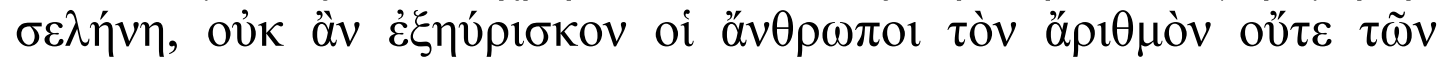

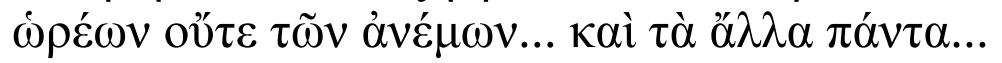

'...he would not say «to many» (but to «all together»), i. e. to those who cultivate the land and those who are engaged in navigation, [signalling] them the hour when the navigation starts. For if there were no moon, humans would not have discovered neither the number of the seasons nor the number of the winds...nor all the rest...'.

The Derveni author starts col. XXIV with an interpretation of the epithet of the Moon i $\sigma 0 \mu \varepsilon \lambda \eta \dot{s}$ (hapax) that must have occurred in the verse from the Orphic theogony quoted in the lost lower part of the preceding column and he takes it in the sense of «circular» on the ground that only circular objects when «measured from the center» (distance to the periphery is meant) have «equal limbs» on all sides. Martin West's suggestion that the lost verse was similar to

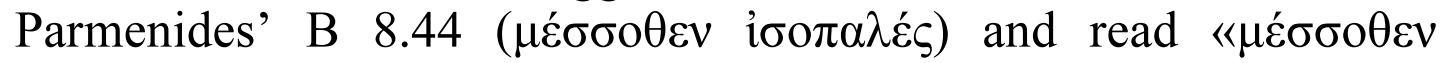
i $\sigma 0 \mu \varepsilon \lambda \eta \dot{\zeta}$ remains attractive, although cannot be proved. In any case the reference to the circular shape of the full moon is plausible. An

\footnotetext{
${ }^{50}$ Note the «agricultural» epikleseis of Zeus the Rain-giver (Hyetios) and Poseidon the Nourishing (Phytalmios).

${ }^{51}$ Nestle 1936: 439 compares Minucius Felix, Octav. 2,21 errando (on «wandering» benefactors) and concludes that Orpheus was included in Prodicus' list of deified inventors.

${ }^{52}$ We follow the subtle suggestion of Kotwick 2016: 3. The distinction between «many» and «all» refers to tekhnitai, on the one hand, and all humanity indiscriminately, on the other.
} 
objection against this interpretation that adjectives ending with $\mu \varepsilon \lambda \eta{ }^{\prime}$ in Greek always refer to «stretched» limbs is not sustainable since in the poetic language $\mu \varepsilon \dot{\lambda} \eta$ (pl.) can be used as a pluralis poeticus for the whole body rather than for some «stretched» parts of the body: e.g. in Parmenides B $16.1 \kappa \rho \tilde{\alpha} \sigma 1 \varsigma \mu \varepsilon \lambda \dot{\varepsilon} \omega v$ $\pi 0 \lambda v \pi \lambda \alpha ́ \gamma \kappa \tau \omega \nu$ «the mixture (i. e. composition) of much-wandering (i. e. constantly changing) limbs (i. e. body)» refers to the condition of the body, not of some limbs, and the Homeric epithet of Eros $\lambda v \sigma \mu \varepsilon \lambda \eta{ }^{\prime}$ «relaxing limbs» refers to the relaxation of the whole body regardless of its shape.

In a second move the commentator doubts the (rather obvious) meaning of the verse about the moon that «shines», i. e. is the source of light, «for many» on the ground that in this case one would expect «shines to all» rather than «to many». Instead he interprets paív indicate) the appropriate hour» for starting various activities, i. e. he tries to connect it with the phases of the moon and the timereckoning. The word «many» is explained as a reference not to all mortals, but to specific groups, namely to «those who cultivate the land» and «those who are engaged in seafaring». To the latter the moon «shows» the time when navigation starts. The author does not specify what exactly the moon «shows» to agriculturalists because it is self-evident: the agricultural cycle of «works and days» (like sowing, harvesting etc.) based on the calendar year and the seasons are meant. Without the moon there would be no timereckoning and calendar, and without these agriculture and seafaring would be impossible. Since the production of food (agriculture) and sea trade are essential for sustaining human bios mortals deified the Moon and the Sun as «that which benefits human life.» This is exactly what we find in the reports on Prodicus' rather peculiar «agricultural» theory of the origin of the belief in gods ${ }^{53}$. The words $\tilde{\tilde{\omega}} \rho \alpha$ and $\dot{\omega} \rho \varepsilon \dot{\varepsilon} \omega v$ in col. XXIV echo the title of Prodicus' work ' $\Omega \rho \alpha 1$. It is reasonable to infer from this passage that in the lost parts of the text of the DervT the Derveni author made similar connections between the Sun and the practical needs of humans, e.g. explaining Helios as a deified «heat» (thermon) useful for agriculture: the connection between the Sun and the Seasons imposes itself. Cf. Helios and

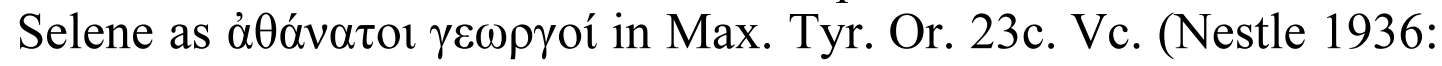
439). Other examples illustrating the importance of explanatory time

${ }^{53}$ Prodic. T 66-78 Mayhew. 


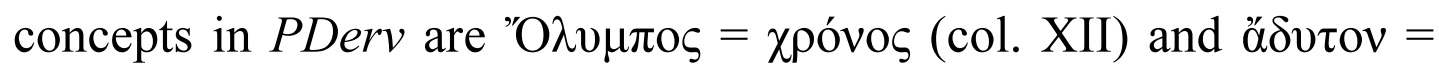

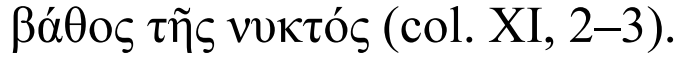

(T4) Aristophanes Clouds: $\Delta \tilde{i} v o \varsigma \beta \alpha \sigma \imath \lambda \varepsilon v ́ \varepsilon ı !$

The text of PDerv. col. XVIII, 1-3

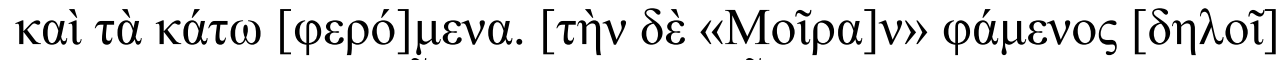

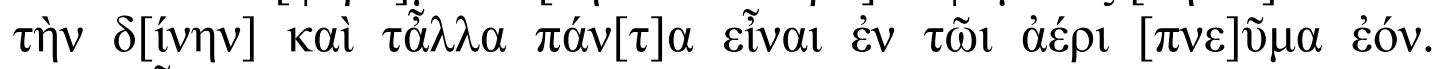

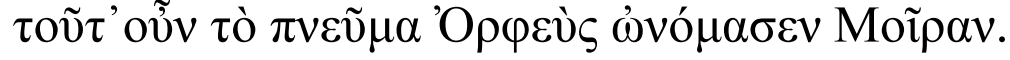

'... and the things that move down. By saying «Moira» he means the vortex and all the rest in the air which is wind. It is this wind that Orpheus called «Moira»'.

The supplement $\tau[\eta ் \delta \delta \varepsilon \gamma \eta े v]$ in col. XVIII, 1 proposed by Tsantsanoglou and Parassoglou, and accepted by Bernabé, is unlikely. First, because teste TLG all instances of this phrase in classical authors come from the tragedy, there is not a single instance of $\eta \delta \varepsilon$ $\gamma \tilde{\eta}, \tau \tilde{\eta} \varsigma \delta \dot{\varepsilon} \gamma \tilde{\eta} \varsigma$ or $\tau \eta \dot{v} \nu \delta \varepsilon \gamma \tilde{\eta} \nu$ in prose, either in classical or in late pose $^{54}$. A possible phrase for «this earth» in Greek prose would be

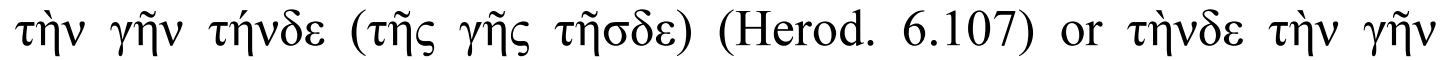
(Demosth. Epitaph. 8), never $\tau \grave{\eta} v \delta \varepsilon \gamma \tilde{\eta} v$ which is an exclusively tragic idiom. And second, in most cases $\dot{\eta} \gamma \tilde{\eta}$ $\eta \delta \varepsilon$ means 'this land' rather than 'this earth' and refers to the polis or region in which the speaker is located in drama, like Athens or Corinth, but such meaning does not fit the context DervT at all. It is conceivable that in an astronomical and cosmological contexts 'this earth' might refer to «our» planet earth as distinguished from another similar planet, but there is no indication in the text of the papyrus that the Derveni author shared either the eccentric cosmology of Philolaus with two earths $^{55}$ or the Ionian theory of the innumerable worlds in the infinite Universe, each with its own earth, the Sun, the Moon etc. ${ }^{56}$

${ }^{54}$ For $\tau \eta ́ v \delta \varepsilon \varepsilon \tilde{\eta} v$ TLG gives 10 classical instances, 7 from Euripides, 2 from Sophocles, one from Aeschylus.There are many more (50) instances of the genitive $\tau \tilde{\eta} \sigma \delta \varepsilon \gamma \tilde{\eta} \varsigma, 28$ in Euripides, 13 in Sophocles, 9 in Aeschylus, none from prose.

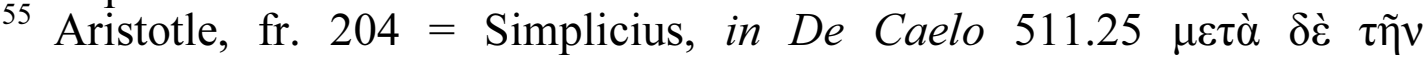

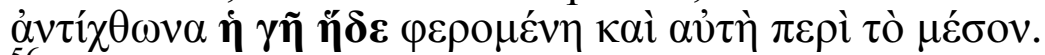

${ }^{56}$ Theoretically the Derveni author could share the latter theory since it is attested in Anaxagoras B 4 that describes extraterrestrials in a cosmos different from ours, apparently in a distant part of the infinite Universe. But the cosmogonical context in col. XVIII in any case has nothing to do with the innumerable worlds. In late prose (Dionysius Halicrnassensis, Cassius Dio, Joseph Flavius et al.) the phrase «this earth» is used as a synonym of oikumene, without antithesis to "another earth», but these contexts are historical, geographical and ethnographical and cannot be compared with 
The most plausible reading that perfectly fits the context is $\tau[\grave{\eta} v$

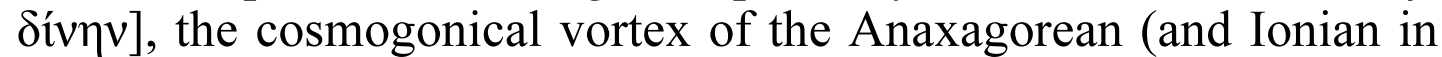
general) physics ${ }^{57}$. Vortex is a form of wind, and wind is motion of air, hence the mention of wind $(\pi v \varepsilon \tilde{v} \mu \alpha)$ and air in the next line $2^{58}$. According to the Ionian mechanics of the vortex heavy bodies move to the center of the vortex, and the light ones to the perifery, this

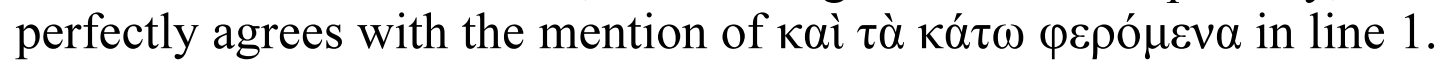
The conjunction $\kappa \alpha$ i presupposes the mention in the preceding lines

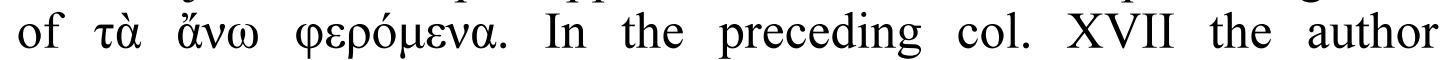
interpreted the «Hymn to Zeus» in terms of Anaxagorean cosmogony. In Anaxagoras' cosmogony the operation of the Nous (identified by the Derveni author with Zeus) produces a vortex.

We take $\pi v \varepsilon \tilde{v} \mu \alpha$ as 'wind', not as 'breath' or 'air' in general.

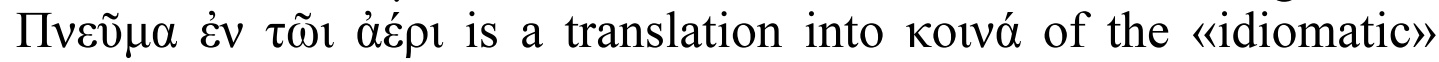
expression $\mu$ oĩp $\alpha \Delta$ lós. The link between Moĩ $\alpha \nu \nu \dot{\varepsilon} \pi 1 \kappa \lambda \tilde{\omega} \sigma \alpha 1$ and the air-cosmogony is transparent: both $\kappa \lambda \omega \theta \omega \omega$ and $\delta \imath v \varepsilon \dot{\omega} \omega$ mean 'to spin'; the author most probably interprets 'the spinning of Moira' as 'whirling of wind'. Moira and ananke pertain to the same semantic field and are often associated, cf. PDerv XXV, 7 The identification

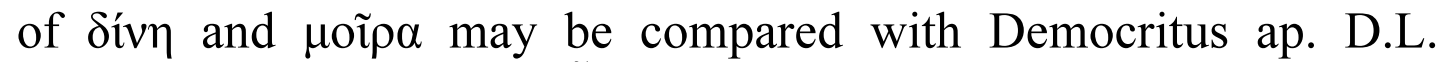

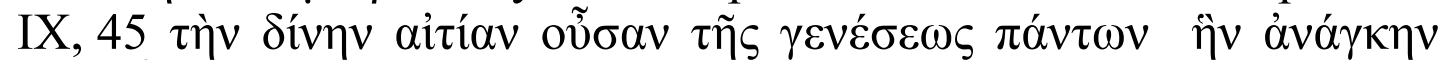
$\lambda \dot{\varepsilon} \gamma \varepsilon{ }^{59}$. The idea of Nous-Vortex determining the past, present and

Derveni papyrus col. XVIII.

${ }^{57}$ I have proposed this supplement in my 1993 Princeton conference paper, and I am glad that Professor Burkert and Professor Janko (ap. KPT, 227) arrived independently at the same conclusion. In Janko 2001: 27 the reading is that of KPT. I am also glad that Valeria Piano 2016: 9 confirmed

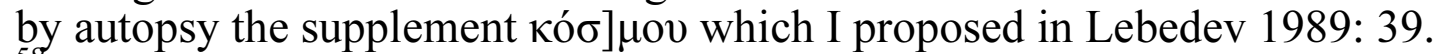
${ }^{58}$ Betegh's objection (p.378) that a vortex cannot be «in the air» is futile:

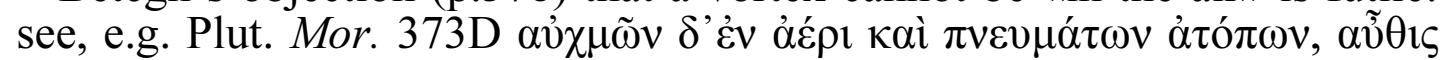

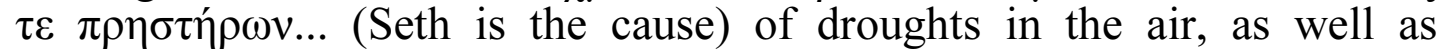
enormous winds and hurricans» or «tornados». Antiphon fr. 29 Pendrick (B

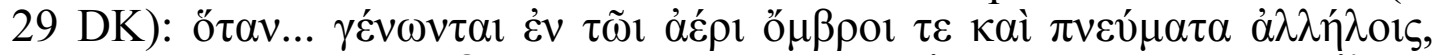

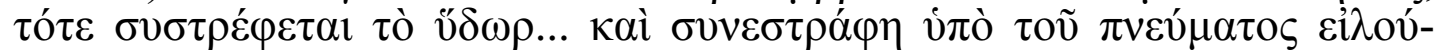
$\mu \varepsilon v o v$... Exactly as in PDerv $\pi v \varepsilon \tilde{u} \mu \alpha$ in such contexts means 'wind', not 'breath'. Antiphon explains the formation of hail (cf. Pendrick, ad loc.), but a similar language is used by the Hippocratic author of De aere 8 in the

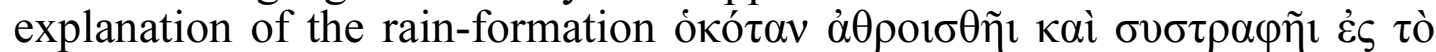

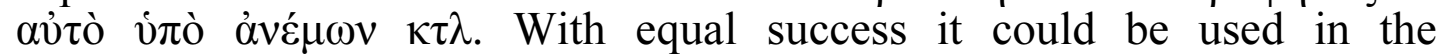
description of the formation of world-masses. In his comment on Antiphon fr. 29 P. Galen overstates his thesis that عì and nothing else. The word $\sigma v \sigma \tau \rho \varepsilon ́ \varphi \varepsilon \sigma \theta \alpha i$ makes it clear that the connotation of 'rolling' and 'winding' is also present, on $\sigma v \sigma \tau \rho \circ \varphi \eta$ ' 'whirlwind' see LSJ, s.v. II, 3.

${ }^{59}$ DK II,84,18-19. Avó $\gamma \kappa \eta$ is a catchword and a fundamental concept in 
future etc. derives from Anaxagoras B 12. It is obvious that dív $\eta$ is intended as an etymon of $\Delta$ ía. Taking into account the uniqueness of this etymology, we can identify Aristophanes Nubes 380 and 828 as quotations from the DervT.

PDerv col. XVII also contains a remarkable parallel to the «linguistic mistake» theory of the origin of religion in Tiresias' logos. According to the Derveni author, when Orpheus said Zev̀s

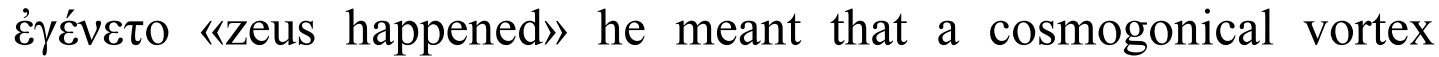

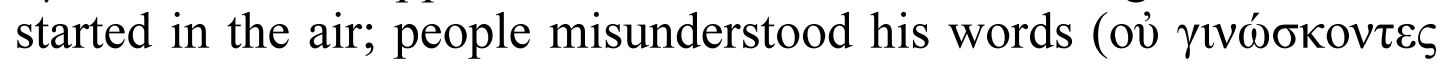
$\tau \grave{\alpha} \lambda \varepsilon \gamma o ́ \mu \varepsilon v \alpha 1.14)$ and decided that someone called «Zeus» was «born». As a result of this misunderstanding an anthropomorphic pseudo-god Zeus is still worshipped by the Greeks. In fact they worship a cosmogonical vortex in the air (which is identical with the

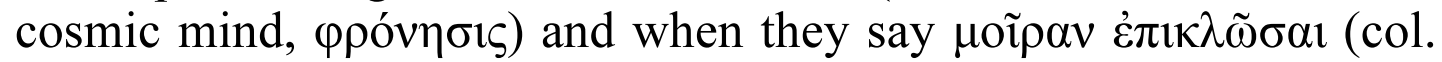
XVII,4) they erroneously think of a mythical Moira the spinner; the original - and the correct - meaning (= whirlwind in the air) intended by Orpheus has been forgotten, so they use the correct words

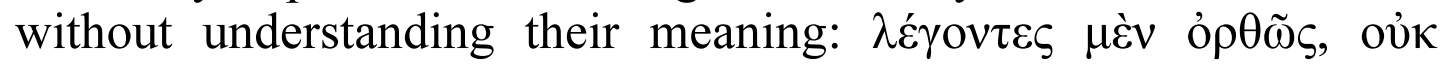

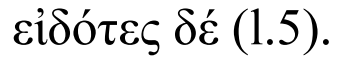

(T5) More parallels between PDerv and Aristophanes' Clouds.

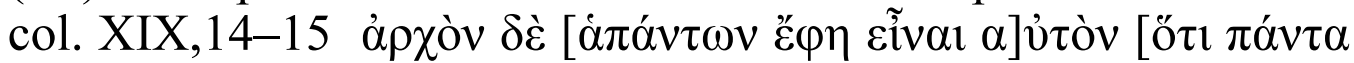

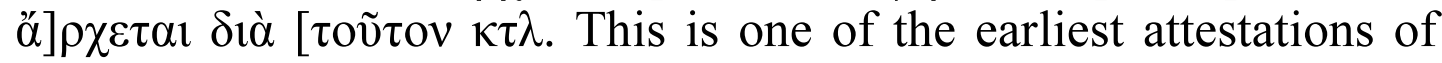
what has become later the standard philosophical etymology of the name of Zeus $\Delta i \dot{i} \alpha=\delta i \alpha$ : Zeus is a universal causa activa that determines everything.

The cosmogonical motif of the «vortex» reappears twice in

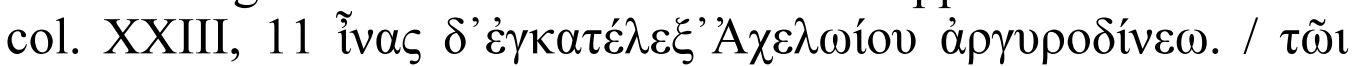

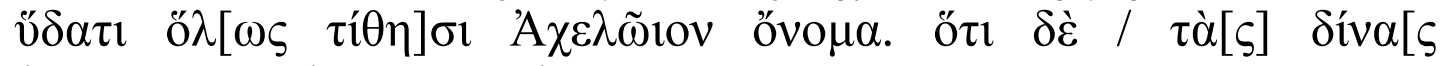

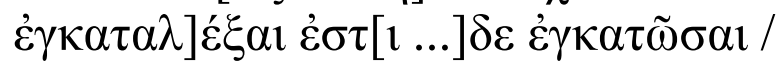

The commentator takes Achelous as a general term for the water element and reinterprets $\dot{\varepsilon} \gamma \kappa \alpha \tau \alpha \lambda] \dot{\varepsilon} \xi \alpha 1$ (West 1983: 115) 'built in' as $\dot{\varepsilon} \gamma \kappa \alpha \tau \tilde{\omega} \sigma \alpha 1$ 'threw down', i. e. Zeus-Air "pushed down water by vortex». This is a plausible source of Aristoph. Nub. 376-381:

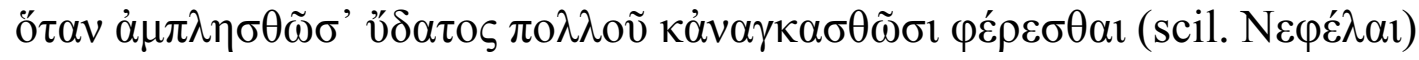

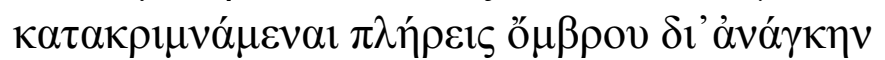

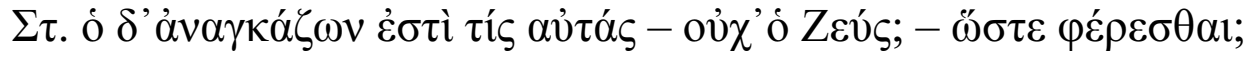

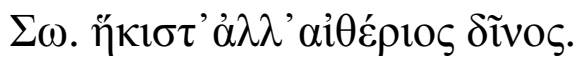

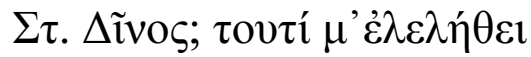

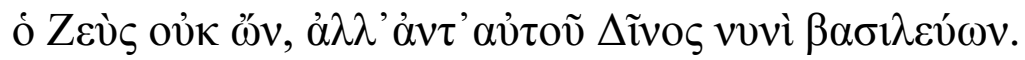

Democritus' cosmogony and mechanics: see the texts 22-30 collected by Luria under the heading «Necessitas naturalis» (Luria 1970: 33-35). 
There can be little doubt that Dinos-Zeus derives from the same

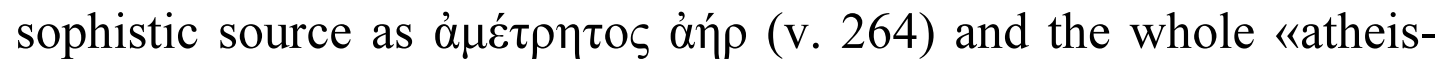
tic» meteoroleschia of the Clouds. This source is almost certainly Prodicus of Ceos who is mentioned by name in v. 361 as a king of meteorosophistai second only to Socrates (Ambrose 1982: 138 on Dinos). Nephelai would not believe to any other meteorosophistes except Prodicus because he surpasses all other sophists in wisdom and judgement, $N u b .360$ :

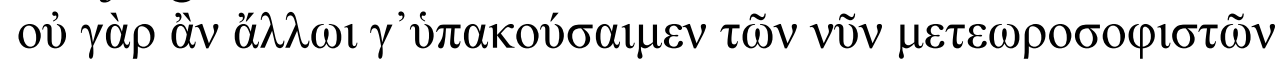

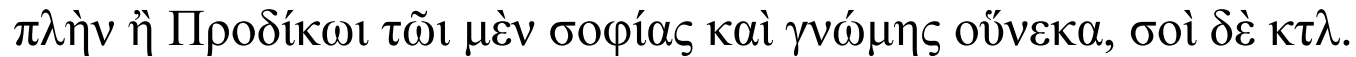

It has been thought by some that the cryptic allusions to mysteries and initiation in the text of the comedy are connected with Eleusinian mysteries (Byl 1995; 2013, etc.). However we should rule out a limine the possibility that Aristophanes is mocking Eleusinian mysteries. The language of mysteries and initiation in Arstophanes is a metaphorical code that exclusively belongs to the iconic, and not to the referential level of text ${ }^{60}$. On the referential level we have the target of this allusions: Socrates and Prodicus who represent all sophists and the new education perceived as a danger to

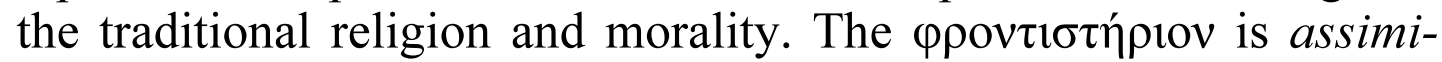
lated to the Eleusinian $\tau \varepsilon \lambda \varepsilon \sigma \tau$ ๆ́pเov by an allusive homoioteleuton.

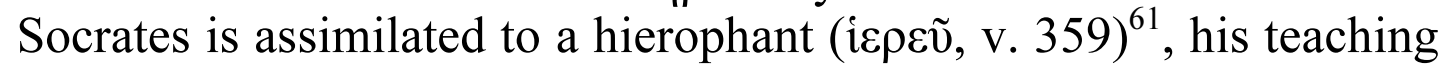
to the initiation, natural phenomena, deified according to Prodicus' theory of religion, are assimilated to the new gods: «Oh my Lord, the Infinite Air», Vortex-Zeus, The Clouds as sources of all kinds of useful knowledge providing to the sophists money and means of

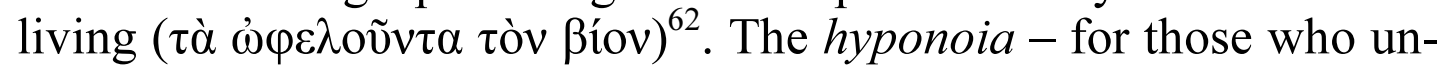
derstand correctly - of this allusions was that Socrates «introduces new divinities not recognised by the polis». By 423 the psephisma of Diopeithes had been already enacted, so Aristophanes' allusions look like a cryptic message addressed to Socrates and Prodicus, an accusation of asebeia and a threat at once. Mayhew has pointed out to additional possible allusions to Prodicus' Horai in Aristophanes'

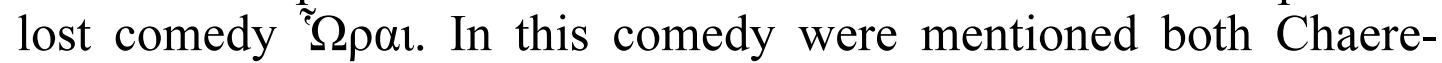
phon, Socrates' associate, and Prodicus' associate Callias whose

${ }^{60}$ Incidentally, the «initiatory» metaphors and analogies were seriously used by philosophical schools themselves, especially in the Pythagorean and Platonic tradition. See Riedweg 1987.

${ }_{62}^{61}$ A unique metaphor in Aristophanes, cf. Taillardat 1962: 287, № 507.

${ }^{62} \mathrm{Nub} .331 \mathrm{ff}$. This is an exact parallel to the birds, the new gods in Aves, who claim to be the source of beneficial things for humans. 
house was a famous club of sophists and intellectuals in Athens ${ }^{63}$. Xenophon the Socratic admired Prodicus. Prodicus' art of the precise distinction of near-synonyms and Socrates' quest for the exact definition of moral concepts display certain similarity and have been compared (on this see Reesor 1983).

Dover's perception of the image of «Socrates» in the Clouds as a composite portrait of a contemporary sophist is essentially correct (Dover 1968: XLIX ff.). All attempts to take the meteoroleschia of Socrates at face value and to ascribe it to some «early stage» of his philosophical career are ill founded ${ }^{64}$. Such attempts would make us to believe that if we place on the scale the combined powerful consensus of Plato, Aristotle, Xenophon and other Socratics that historical Socrates was predominantly or exclusively moral philosopher who dismissed as worthless the Ionian «natural history» (including Anaxagoras), on one side, and an isolated grotesque and malicious cartoon in a politically motivated comedy, on the other side, the latter will have more weight. However, Dover somewhat underestimated the «proportion» of Prodicus' features in this composite portrait $^{65}$. In what Dover (Dover 1968: lv) describes as a «grotesque anticlimax» (v. 359-363) the Clouds assure Socrates that they would not listen to any other «meteorosophist» except Prodicus and Socrates, the first because of his wisdom and judgment, and the second because of his meaningless wanderings barefoot on the streets and enduring all kinds of discomfort. Prima facie this anticlimax looks like a comical absurdity, but behind it lurks Aristophanes' excuse for ascribing to Socrates the cosmological «wisdom» of Prodicus. It is Prodicus who has knowledge of this science and is the leading «meteorosophist», Socrates is just an uneducated and wretched vagabond. The image of an ó $\sigma \tau \varepsilon \gamma o \varsigma$ vagabond enduring evils ( $\kappa \alpha \alpha \alpha$ ) is an allusion to the popular

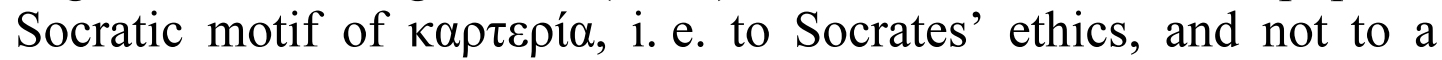
physical doctrine he never held, whereas the alleged «ignorance» of

${ }^{63}$ Aristoph, fr. 583-84 K.-A.; Mayhew 2013: 247-248. We discuss the subject in detail and propose a new reconstruction of the plot and an attribution of a neglected fragment from this comedy with a scene in the house of Callias (and probably Prodicus himself speaking) in the forthcoming Lebedev 2019.

${ }^{64}$ Contra Janko 2001: 13, who tries to revive the implausible hypothesis of Winspear, Silverberg 1960: $11 \mathrm{ff}$.

${ }^{65}$ This was corrected by Willink 1983: 26: «...the arch-sophistic «Socrates» satirised in the play is in several features (e.g. fee-taking, philological quibbling, heretical cosmology) specifically modelled on what we may take as to have been the popular view of arch-sophist Prodikos»». 
Socrates may be Aristophanes' mocking parody of Socrates' sceptical thesis $\tilde{\varepsilon} v$ oĩ $\delta \alpha$ ö $\tau 1$ oủ $\delta \grave{\varepsilon} v$ oî̃ $\delta \alpha$.

(T6) The quasi-Orphic ornithogony in Aristophanes' Birds, 709 ff. is introduced by a direct reference to Prodicus (Av.692). The choir of birds sings:

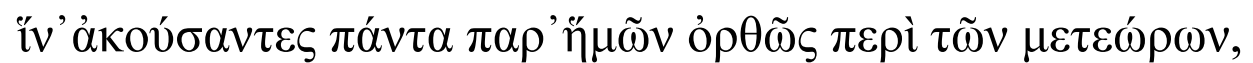

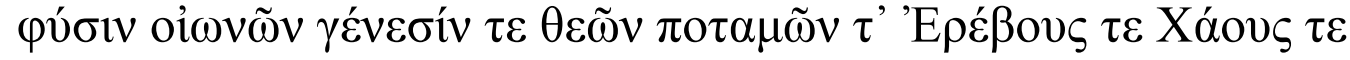

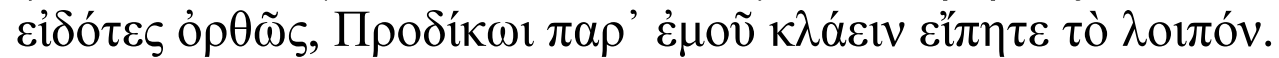

'..you (= humans) will hear from us everything in the correct way about celestial things, the nature of birds, the origin of gods, as well as of rivers, of the Chaos and Erebos, and once you know all this correctly, you may tell Prodicus to weep for the rest of his life'.

The birds' cosmogony is with good reason included in the editions of Orphica as an early evidence on the Attic version of the Orphic theogony with the primeval Nyx (rather than Chronos as in Rhapsodies) who produces the world-egg from which the first-born god (Eros) comes out. But it would be preposterous to take this text as parody of "Orpheus' theogony» itself. First, because to mock a hieros logos in Athens after the psephisma of Diopeithes was a risky enterprise, and second, because the emphatic mention of Prodicus from the start is left unaccounted and unintelligible. Since we know now that Prodicus wrote an allegorical naturalistic interpretation of Orphic theogony, we must admit that the target of Aristophanes' agonistic mockery is Prodicus' allegorical interpretation of the Orphic theogony rather than the Orphic theogony itself ${ }^{66}$. It is hard to imagine that the rather traditional in his system of values poet could mock a hieros logos. And it is only natural that he ridicules an «atheistic» interpretation of a hieros logos.

The birds' version of the origin of the world and their «ornithological» explanation of the origin of gods (agonistically counterposed to the «meteorosophistic» one of Prodicus) and of the meaning of the Orphic cosmic «egg» will surpass Prodicus in the

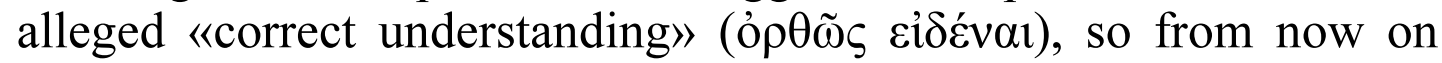
one may forget about Prodicus' history of the human race and his theory of the origin of religion allegedly supported by the «evidence» of the «ancient poetry» of Orpheus. The word o $\rho \theta \tilde{\omega} \varsigma$ "correctly» is emphatically repeated twice; it alludes to Prodicus" terminology and his claims of «correctness» ó $\rho$ ó $\tau \eta \varsigma$, the phrase

${ }^{66}$ For a survey of modern opinions see Bernabé PEG II/1, 73 ad fr. Orph. 64. 


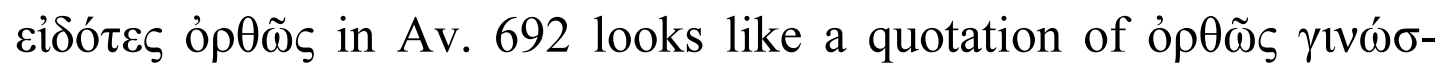

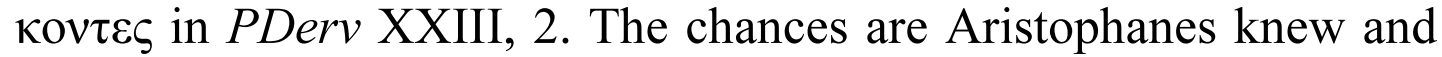
perfectly understood that Prodicus' playful interpretation of the Orphic theogony as an alleged proof of the antiquity of Anaxagoras' physiologia was a hoax and a mockery of religious conservatives like Diopeithes. In this case the purpose of his mock cosmogony was to surpass Prodicus in mockery and to ridicule the sophistic Kulturgeschichte thus defending the traditional values of an ordinary Athenian. Mayhew with a very good reason criticises Diels-Kranz for their underestimating of the importance of the Parabasis of chorus in «Birds» as evidence on Prodicus' doctrines and prints under Text 69 verses 685-725 which expand the cosmogony in narrow sense by preceding v. 585-589 (the original miserable condition of humanity) and following after the mention of Prodicus verses 693-722 which apart from theogony contain a parody of Prodicus' «utilitarian» theory of religion.

We understand these verses as follows: after you hear our Theogony, you may say good-bye to the one of Prodicus. Prodicus' Horai are parodied in the context Av. 708:

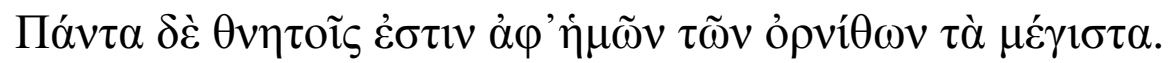

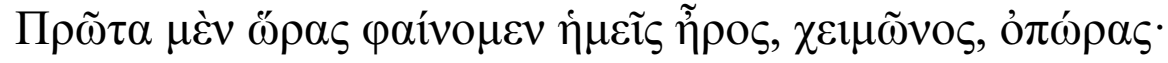

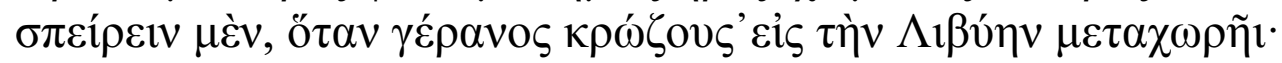

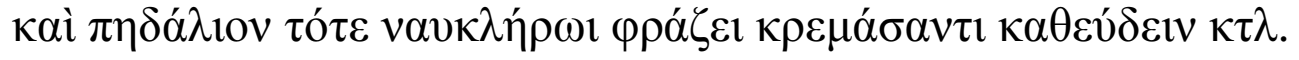

'And the greatest things for mortals are from us, the birds. First, we make known the seasons: spring, winter, and summer; when migrating to Libya the crane cries «Sow your seeds» - and tells the shipowner «Time to hang up your rudder and sleep»". (tr. Mayhew).

The «greatest things» ( $\tau \grave{\alpha} \mu \varepsilon ́ \gamma 1 \sigma \tau \alpha)$ in this context are synonymous with the «most useful things».

According to Prodicus' theory of the origin of religion humans

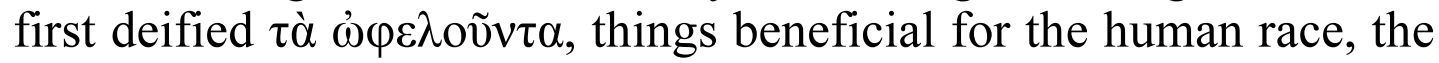
elements, the sun and the moon, indispensable for agriculture. PDerv. col. XXIV describes the usefulness of the moon for the timereckoning and the recognition of the seasons: without the moon agriculture and navigation would be impossible. The choir of the birds after announcing a competition with Prodicus, claims that humans have been taught to distinguish the seasons by the «signals» sent to them by birds; without birds there would be no agriculture and navigation. Exactly the same crafts are mentioned in exactly the same order in PDerv. XXIV, 8-9. The hyponoia of this in Aves is: the utility of birds for the human race far surpasses that of the 
traditional gods and of Prodicus' «useful things», therefore the birds win the agon with Prodicus, they should be deified for their utility and proclaimed new gods. A number of other useful crafts managed by birds' signals is adduced in the following lines: the crane signals when to weave (voaiveıv) a winter-cloak, «the kite appears after this

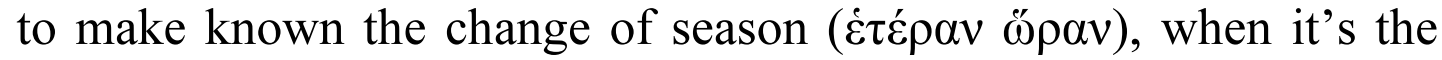
season to shear ( $\pi \varepsilon \kappa \tau \varepsilon i v)$ ship's wool, in spring; then the swallow appears when it's necessary to sell $(\pi \omega \lambda \varepsilon \tilde{\mathrm{i} v})$ the winter cloak and buy $(\pi \rho i \alpha \sigma \theta \alpha \imath)$ some summer clothes ${ }^{67}{ }^{67}$. The birds are equally indispensable for trade ( $\left.\pi \rho \mathrm{ò}_{\varsigma} \dot{\varepsilon} \mu \pi \mathrm{o} \operatorname{li}^{\alpha} \alpha \mathrm{v}\right)$, for getting means of living

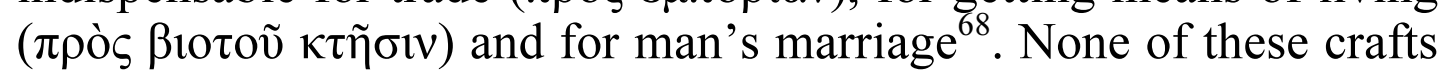
(except agriculture and navigation) is attested nominatim either for Prodicus or in PDerv., but this may be due to the chance and the fragmentary state of our sources. Themistius' encomium of agriculture ascribes to Prodicus the theory that agriculture is the cradle of religion, civilisation and all human crafts. It is hardly accidental that in birds' competition with Prodicus different crafts are correlated with different «Seasons» ( $\tilde{\Omega} \Omega \alpha \iota)$.

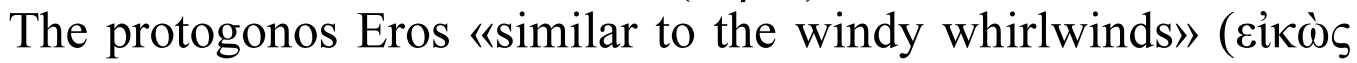

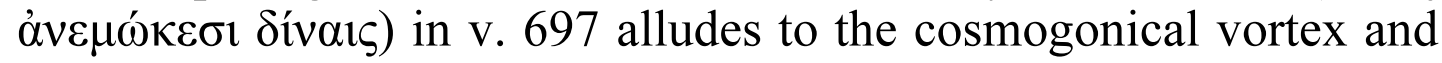
connects the Ornithogony of the Birds with the cosmology of the Clouds.

(T7) The very idea to «surpass» Prodicus' allegorical cosmogony in the comical agon in Aves by substituting for the natural elements the image of «birds», the new gods of the dream-city of eternal happiness, more powerful and more «beneficial» for the human race than Zeus and the Olympians, seems to have been suggested to Aristophanes by another passage of DervT (Prodicus), i. e. column II in which we propose one new reading:

col. II, v.6-8

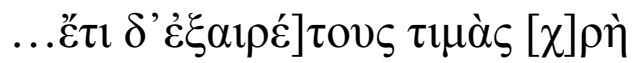

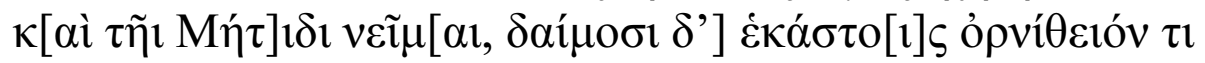

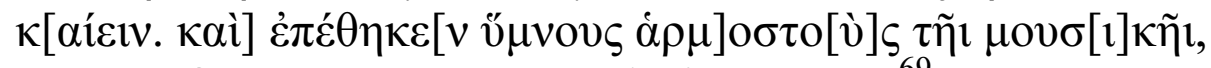

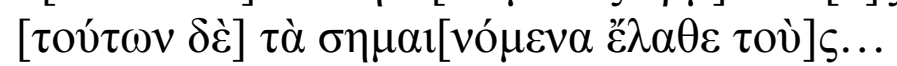

'And besides that [scil. besides honouring Erinyes], one should offer exceptional honours to Metis and burn something avian. And he

\footnotetext{
${ }_{68}^{67}$ Aves, $712-715$, tr. Mayhew with slight alterations.

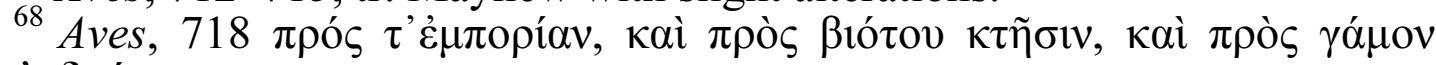
ảv $v$ jós...

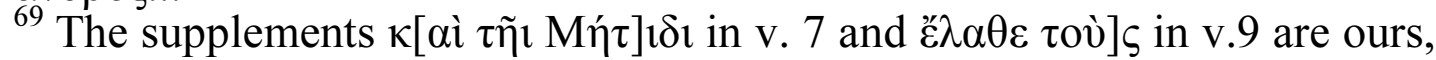
the rest by KPT.
} 
[= Orpheus] added hymns [or poems] that suit the music, but their meaning escapes... [scil. those who lack understanding]'

The reading $\tau[\tilde{\eta} \imath$ Ev̉ $\mu \varepsilon v] \hat{\delta} \delta 1$ in the beginning of v.7 proposed in KPT is unlikely for two reasons. First, such "collective singular» (Kouremenos, 144) is unlikely as such and is not attested. Second, the honouring of Erinyes has already been mentioned in the preceding lines, this makes é $\tau 1$ «and besides that» pointless. In the lines 6-7 the author adds to the honouring of Erinyes the honouring of yet another ( ${ }^{\prime \prime} \tau 1$... Kaí) daimon and the requirement of avian offerings to all daimones (i. e. not only Erinyes-Eumenides). It is hard to find a more plausible name of a daimon ending on $-1 \delta 1$ in dative than Metis attested in col. XV:

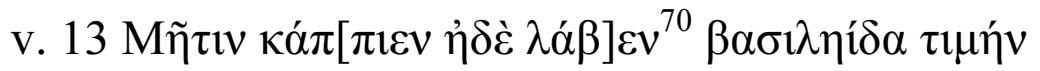

'[Zeus] swallowed Wisdom (Metis) and received the royal honor'.

The author of the Derveni theogony (Onomacritus, according to Aristotle) borrowed from Hesiod, apart from the large part of the succession myth, the epithet of Zeus $\mu \eta \tau i \varepsilon \tau \alpha$ which is attested in PDerv. col. XV,6.11. It is hard to see why he could not borrow the kataposis of Metis in Hesiod, Th.886-900 as well. The phrase $\beta \alpha \sigma i \lambda \eta i \delta \alpha \tau \mu \eta \eta v v$ quotes Hesiod Th.892. ${ }^{71}$ He adapts it to the Orphic narrative: Zeus follows the prophecy of Night and Kronos rather than that of Ouranos and Gaia, Metis is not a just a personification of Wisdom and not Zeus' "first wife» (Rhea-Demeter in col. XXVI), but one of the names of the daimon Protogonos.

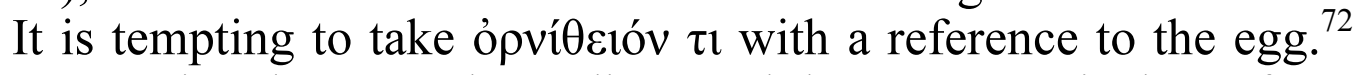
The Derveni author must have discussed the cosmogonical egg from which Protogonos «sprouted first» in the lost parts of the papyrus. It has been preserved in Aristophanes' ornithogony, ${ }^{73}$ the Derveni author may have allegorically interpreted it as an anaxagorean

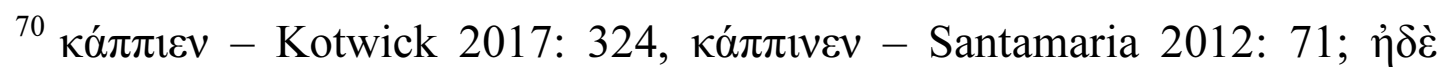

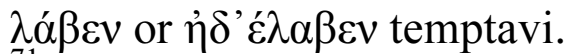

${ }_{71}$ Contra KPT 213 who are on this point vague and indecisive.

72 Janko (2016) 19 questions the reading opví $\theta \varepsilon 10 v$ in col. VI, 11 (KPT) and

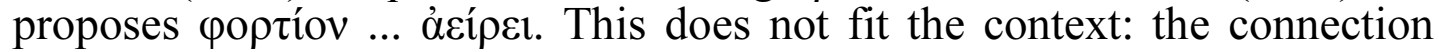
with prothysia is lost, हैvekev becomes pointless, what is meant by the «labouring souls» remains unclear. On the contrary, the reading ópvíteciov (KPT) or ópví日ıv (Ferrari, followed by Piano) provides an immediate link with the air-cosmogony and with prothysia: first offerings are due to the

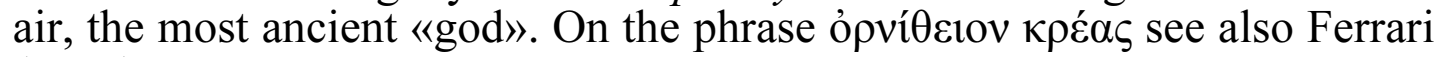
(2007) 204.

${ }^{73}$ So rightly Brisson (1990) 2876-77, contra Betegh (2006) 148. 
mixture of various «seeds» of all things, cf. a similar naturalistic interpretation of the Orphic egg in the Pseudo-Clementina. ${ }^{74}$

Avian offerings are for the second time mentioned in col. VI,811: «Mystai perform preliminary sacrifice $(\pi \rho 0 \theta v ́ o v \sigma \imath)$ to Eumenides in the same way as magoi, for Eumenides are souls

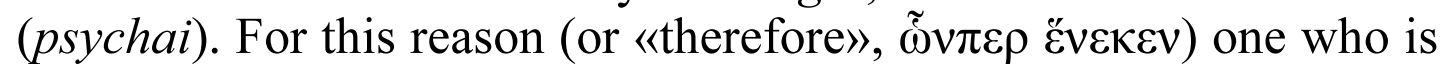
going to sacrifice to gods [would] first offer something avian (opvíteiov)...». Why the identity of Eumenides/Einyes with the souls is presented as a necessary reason to sacrifice first «something avian»? This prima facie strange inference can be explained only on the ground of the allegorical interpretation of Eumenides-souls as «air». In Greek popular «folk-zoology» and in Empedocles the three elements (world-masses) of earth, sea and air (sky) were correlated with three kinds of animals: terrestrial animals, fishes and birds. The Derveni author is not a priest and he does not give in these lines ritual prescriptions, he «decodes» in the teletai established by Orpheus the same «ancient wisdom» as in his poetry. The commentator assumes that first offerings are due to the first gods. Both magoi and mystai converge in that they first make offerings to the souls that, like birds, reside in the air and (according to commentator) are nothing but air. ${ }^{75}$ It follows that the ancient religion accords with the modern science: both in Orpheus and in the Anaxagorean physics «air» is the original source of everything. ${ }^{76}$ Once we admit that PDerv is a work of Prodicus parodied by Aristophanes, it is reasonable to conclude that the choice of «birds» as «new gods», more «ancient» than Olympians, in Aves was also suggested to Aristophanes by the same work on the origin of religion and was intended as a mocking parody of it.

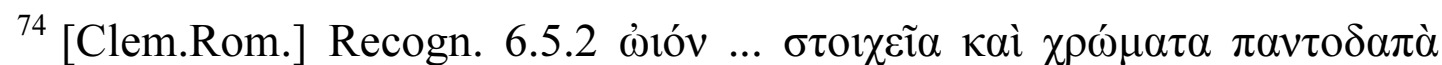

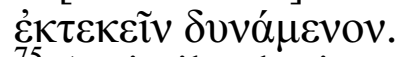

${ }^{75}$ A similar logic underlies the discussion of the etymology of Hestia in Plato's Cratylus, 401c1 - d7: Hestia genealogical priority can be deduced from the fact the she comes first in the order of sacrifices. On the topic see Sedley (2003) $99 \mathrm{ff}$.

${ }^{76}$ Some modern commentators of PDerv do not seem to realize that in Anaxagorean physics there is no contradition between the conception of matter as a mixture of various «seeds» (spermata) and «air». Both in Anxagoras and in Democritus the traditional four «elements» are not «chemical» elements (immutable simple substances, as in Empedocles), but phenomenal aggregate states of matter: gaseous, liquid, solid. In Anaxagoras' cosmogony the original (precosmic) universal mixture

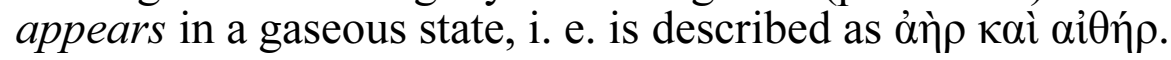


(T8) A metaphorical scene of prothysia appears in another comedy that targeted Prodicus' air-cosmogony and exposed its «atheistic» implications. In Nubes 606-8 Strepsiades experiences sacred awe as he enters the Phrontisterion, the entrance of which is compared with a ritual katabasis to the oracular cave of Trophonius;

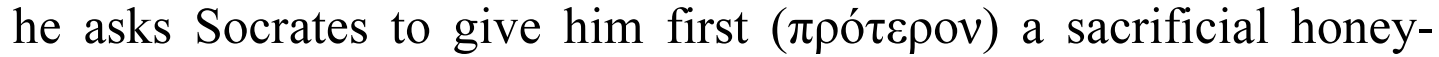
cake $(\mu \varepsilon \lambda \imath \tau \tau o \tilde{\tau} \tau \alpha v)$. So, before the initiation ( $\tau \varepsilon \lambda \varepsilon \tau \eta \dot{)}$ ) into the mysteria of the sophistic wisdom inside the phrontisterion the old man wishes to perform the «preliminary offering» $(\pi \rho \circ \theta v \sigma i ́ \alpha)$ of honey-cakes to placate the "wise souls» that inhabit the school of

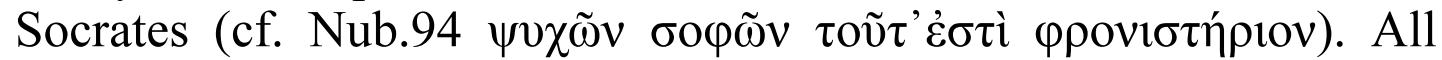
this looks like a parody of PDerv VI.

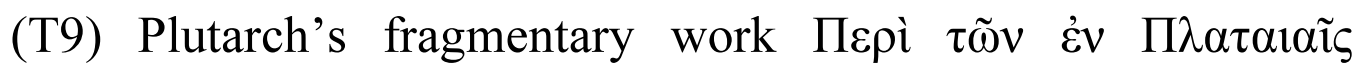
$\Delta \alpha 1 \delta \alpha \dot{\lambda} \omega v$ seems to draw on several sources one of which looks like a summary exposition of something very similar to the Derveni treaise $^{77}$ :

Plutarch, fr. 157 Sandbach ap. Eusebius, Praep. Ev., Proem. 3, 1,1:

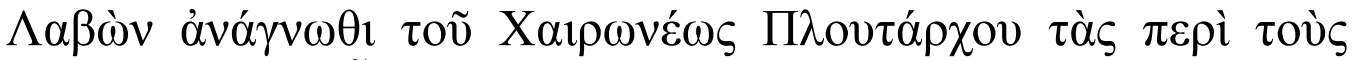

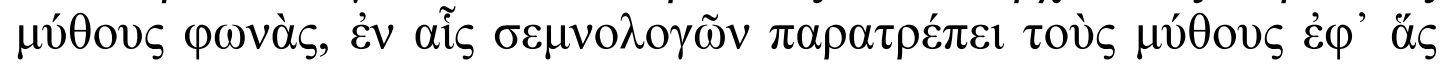

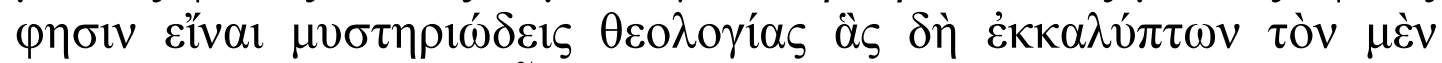

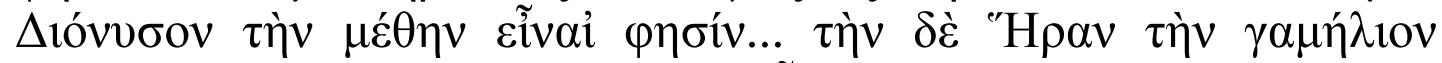

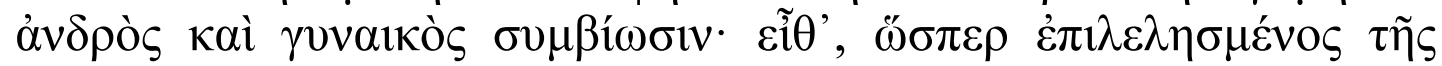

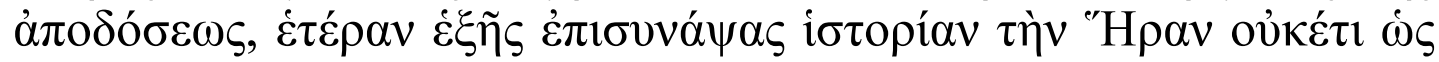

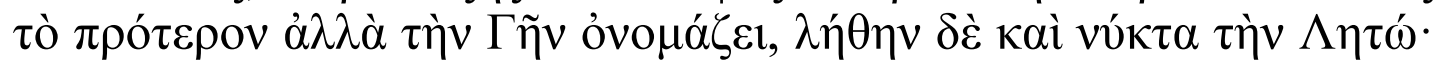

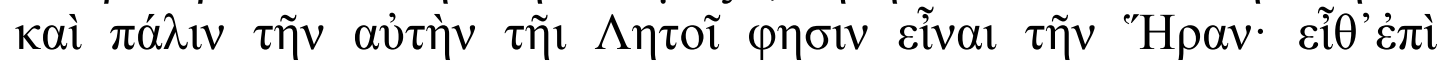

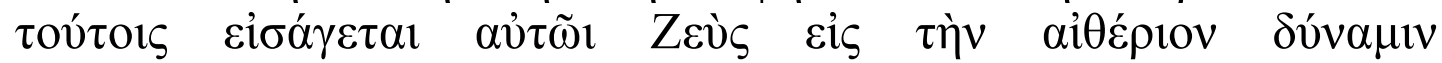

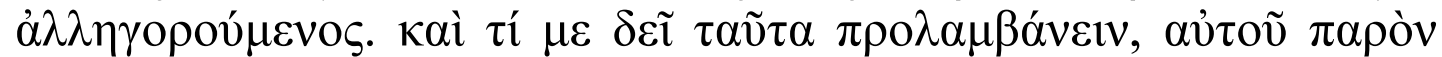

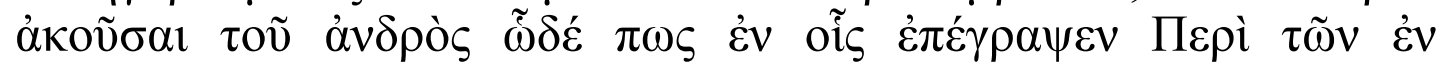

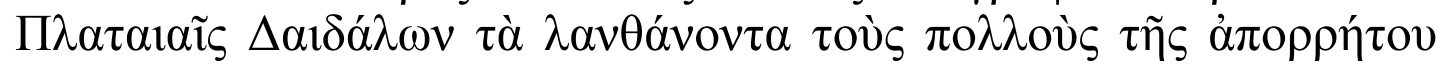

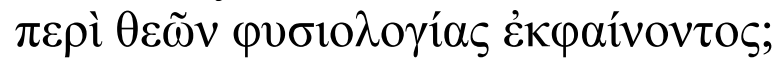

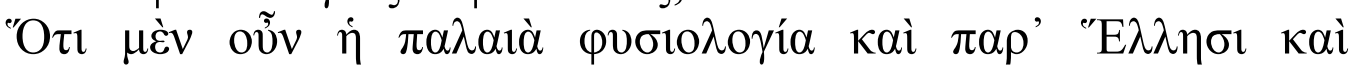

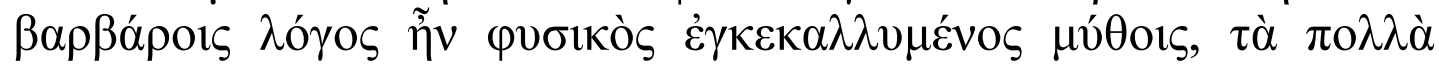

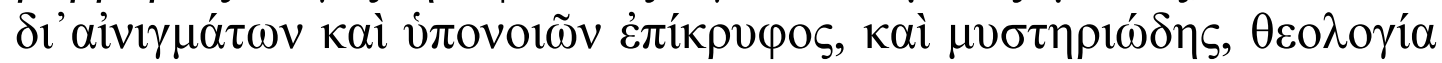

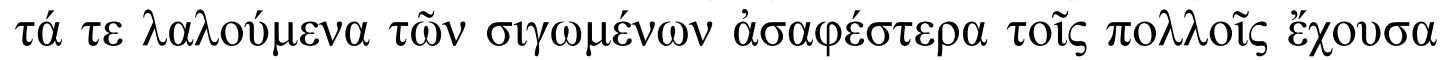

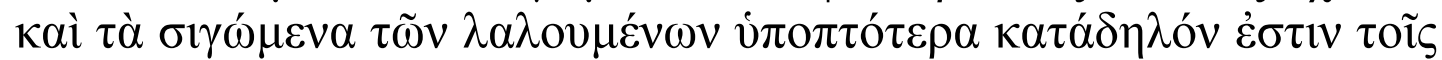

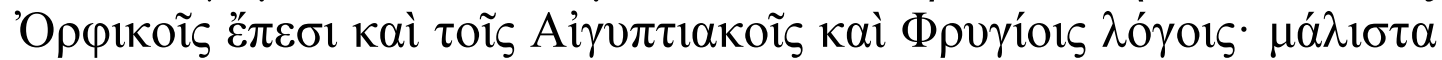

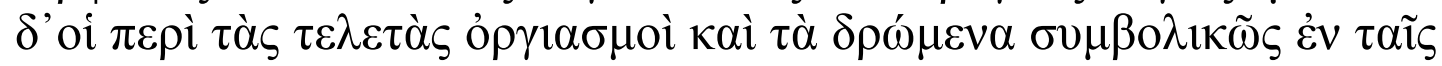

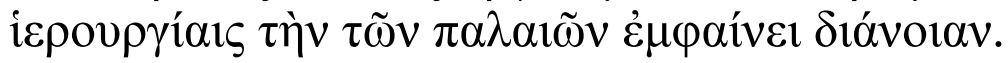

${ }^{77}$ Parts of this text in: Orph. fr. 671 Bern. $=$ Diagoras Melius fr. 94 Win. $=$ FGrHist 800 T9. 
'Take up Plutarch of Chaeronea and read his statements about our subject, statements in which he majestically converts the myths into what he says are "mystic theologies»; purporting to reveal these, he says that Dionysus is intoxication ... and Hera the married life of husband and wife. Then, as if he has forgotten this interpretation, he tacks on directly afterwards a different account: contrary to his previous view he now calls Hera the earth, and Leto forgetfulness and night. Then again he says that Hera and Leto are identical; next on top of this Zeus is introduced, allegorised into the power of aether. Why should I anticipate all this, when we can listen to the fellow himself? In the work he entitles On the Festival of Images at Plataea he discloses what most men are unaware of in the secret natural science that attaches to the gods, and does so as follows.

1. Ancient natural science, among both Greek and foreign nations, took the form of a scientific account hidden in mythology, veiled for the most part in riddles and hints, or of a theology as is found in mystery-ceremonies: in it what is spoken is less clear to the masses that what is unsaid, and what is unsaid gives more speculation than what is said. This is evident from the Orphic poems and the Egyptian and Phrygian doctrines [logoi]. But nothing does more to reveal what was in the mind of the ancients than the rites of initiation and the ritual acts that are performed in religious services with symbolical intent'. (tr. F. H. Sandbach with slight alterations).

Note the following similarities of Plutarch's source with the Derveni treatise. The enigmatic Orphic poetry and mysteries are taken as survivals of the ancient physiologia, alternative rationalistic interpretations confuse the reader, equations of gods $\mathrm{Ge}=$ Hera $=$

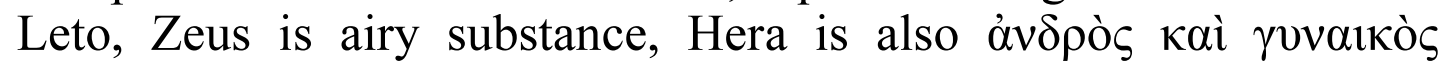

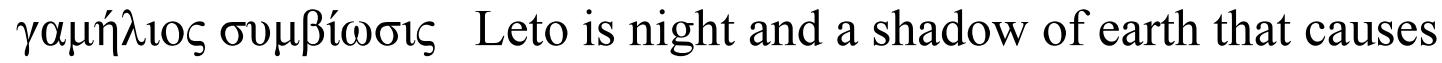
eclipses of sun. The identification Hera $=\mathrm{Ge}$ is found in PDerv col. XXII,7. Dionysos $=$ wine is attested for Prodicus in T 71,74,76 M. and in the passage of Themistius quoted above (T 77). $\Lambda \eta \tau \dot{\omega}=\lambda \eta \dot{\theta \eta}$ is found in Plato's Cratylus 406 a8. The etymology of the name of

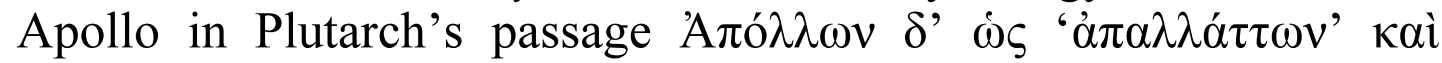

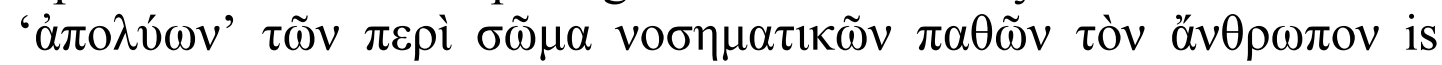

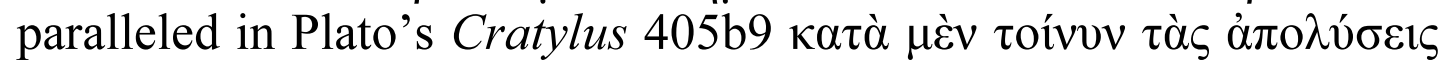

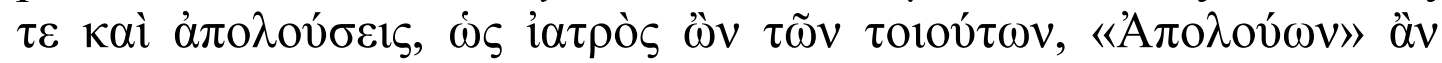

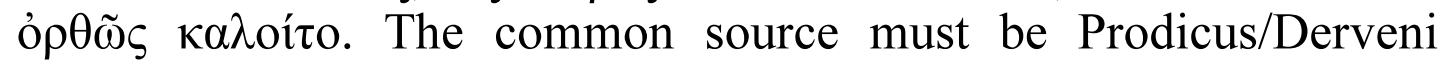
author.

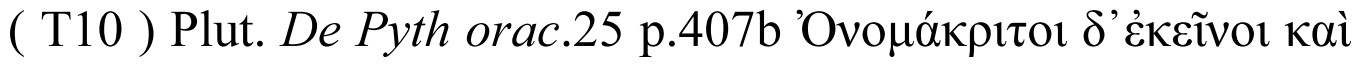

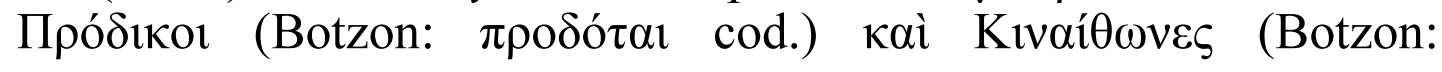




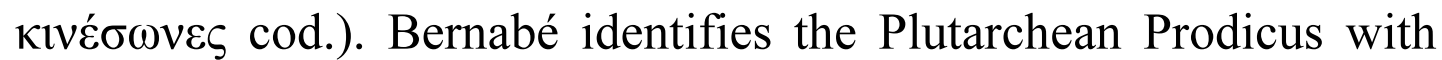

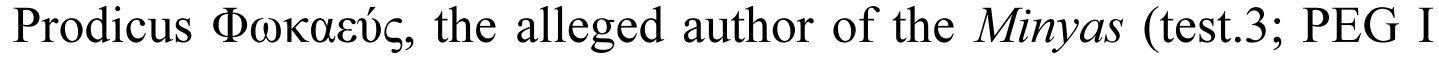
137). However Plutarch gives a list not of epic poets qua poets, but of $\chi \rho \eta \sigma \mu о \lambda$ ó ${ }^{\circ}$ and (from his point of view) pretentious charlatans

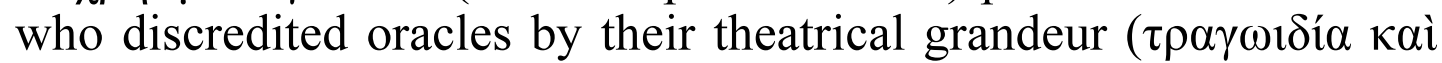
ö $\gamma$ ко $)$ which he contrasts with the simple style of the genuine oracles of Pythia. The Rhapsodic Theogony was not a literary

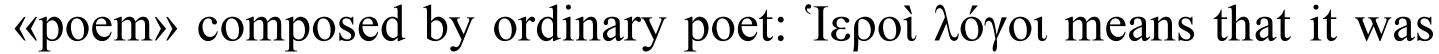
conceived and presented as divine word, as a kind of $\chi \rho \eta \sigma \mu o ́ s$ inspired by Apollo, Orpheus being his prophet. It is possible

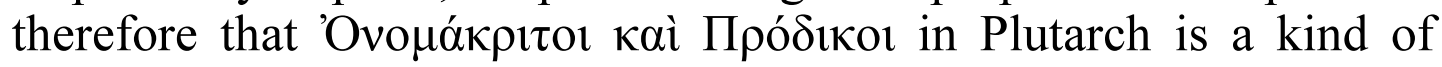
hendiadyoin that refers both to the bombastic Theogony of pseudoOrpheus falsified by Onomacritus and its disreputable and scandalous (in Plutarch's opinion) interpreter Prodicus. ${ }^{18}$

(T11) Apart from the sun and the moon Epiphanius includes in the list of the deified «beneficial» things of Prodicus theory of

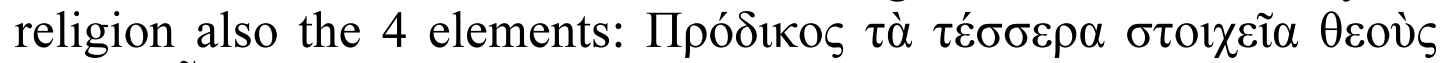

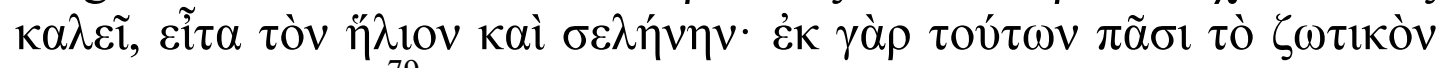

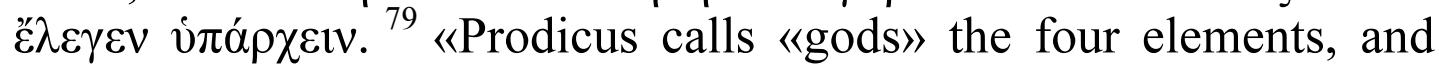
then the sun and the moon, for it is from them, in his opinion, that all men get their means of living». All six are attested in the allegoresis of PDerv as «real» referential meanings of the mythical names: according to the Derveni author, air (and mind) was deified as «Zeus», fire and sun as Protogonos, water element as Acheloos, earth (Ge) as Demeter, the moon as Selene. A very similar naturalistic interpretation of the Greek mythology was parodied as «atheistic» already by Epicharmus ${ }^{80}$.

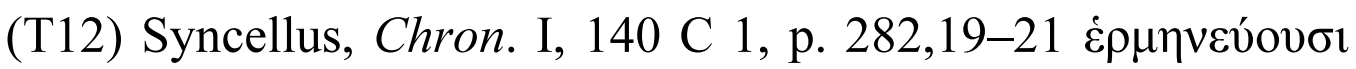

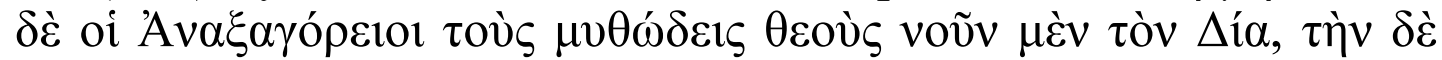

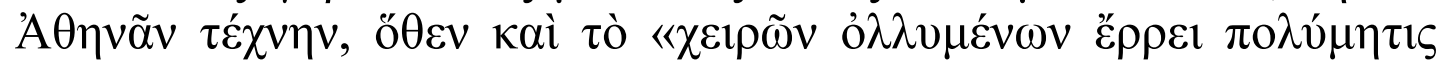

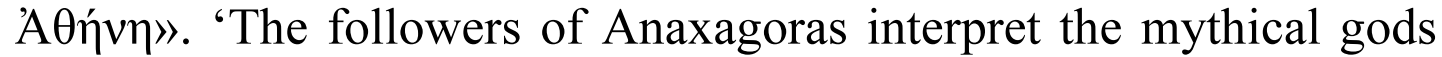
as follows: Zeus is mind (nous), and Athena is technical skill (tekhne), whence the verse «once the hands have perished, the skilful Athena is gone»'.

${ }^{78}$ Clement Alex. attributes Orpheus' «Descent to Hades» to a certain Prodicus of Samos: Strom. I, 131, 3 (vol. II, p. 81, 9 St.) = OF 707 B. $\tau \eta ́ v$

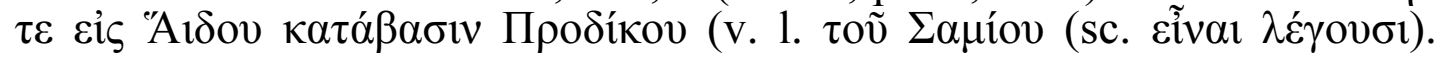

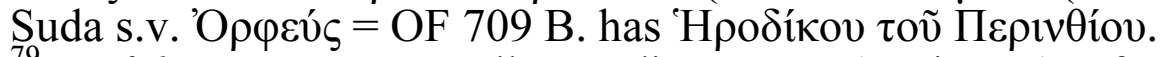

\footnotetext{
${ }^{79}$ De fide, 9, 25; p. 507 Holl = Prodic. T78 M. (not in DK). Cf. Cole 1990: 156.

${ }^{80}$ Fr. 199 K.-A. For a detailed comparison with PDerv. see Lebedev 20174: $19-22$.
} 


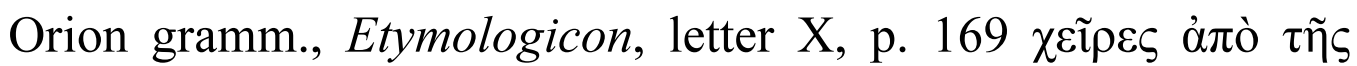

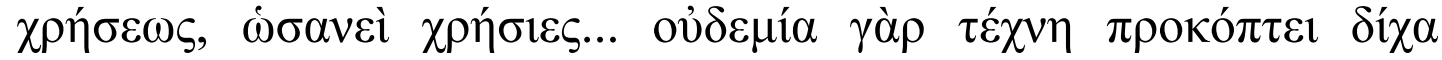

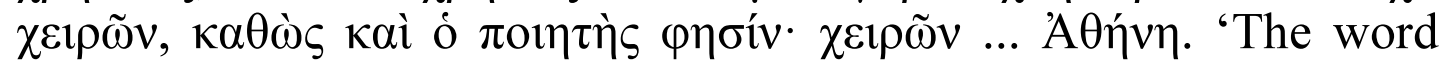
kheires «hands» comes from khresis «use» for no skill (tekhne) advances without hands; as the poet says: "once the hands...»" etc.

This is a rare evidence that directly links the Anaxagorean allegoresis of the Greek mythogoly specifically with the Orphic poems ${ }^{81}$. Diels-Kranz identify these «Anaxagoreans» with Metrodorus of Lampsacus ${ }^{82}$. But there is no evidence that Metrodorus worked on Orphic poems, the attested title of his allegorical work is «On Homer», and all cited examples of his allegorical interpretations concern Homeric gods and heroes. The interpretation of Zeus as mind (nous) is attested in PDerv, but not for Metrodorus. According to Tatianus Metrodorus interpreted Athena not as tekhne, but as a physical element or an arrangement of elements. Prodicus' theory of religion originating from agriculture and other tekhnai that were useful for human race seems to be a more plausible source. The battle of ideas between the Ionian naturalists (adepts of the naturalistic monism) ${ }^{84}$ and religiously minded dualists in the second half of the 5th century BC in Athens was perceived by the contemporaries as a conflict between Anaxagoreioi and Pythagoreioi (cf. note 24 above). Most sophists joined the former camp, so they were no less Anaxagoreioi than Metrodorus, possibly even more.

The verse is quoted by three Byzantine authors and by a $5^{\text {th }}$ century grammarian Orion. Only Orion attributes the verse to Orpheus. Orion followed by Meletius $\left(9^{\text {th }}\right.$ c.) quotes the verse on Athena as tekhne to support the etymology $\chi \varepsilon \tilde{\imath} \rho \varepsilon \varsigma-\chi \rho \dot{\eta} \sigma \varepsilon l \varsigma$. Syncellus $\left(8^{\text {th }} \mathrm{c}\right.$.) and Cedrenus $\left(11^{\text {th }} \mathrm{c}\right.$.) quote it as supporting the rationalistic interpretation of the myth about the creation of man by Prometheus. Both Kern and Bernabé are right when they print in their editions of Orphic fragments $\pi$ o $\lambda v \varepsilon \varepsilon \rho \gamma o \varsigma$, a very rare epithet unlike $\pi \mathrm{o} \lambda u ́ \mu \eta \tau \iota \varsigma$, the standard epithet of Odysseus in Homer. ${ }^{85}$ But

\footnotetext{
${ }^{81}$ Orph. Fr. 856 Bernabé.

${ }^{82}$ Diels - Kranz, VS. 61, 6. cf. Sider 1997: 138.

${ }^{83}$ Metrod. 60, 3 DK = Tatian. Adv. Graecos, c. 3.

${ }^{84}$ On our use of the terms «monism» and «dualism» see explanatory notice in section (7) below.

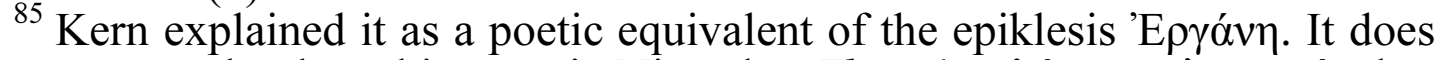

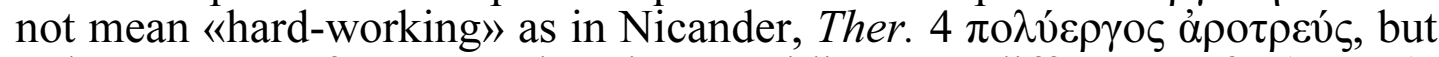
rather «master of many works», i. e. presiding over different crafts ( $\tau \dot{\varepsilon} \chi v \alpha \imath)$.

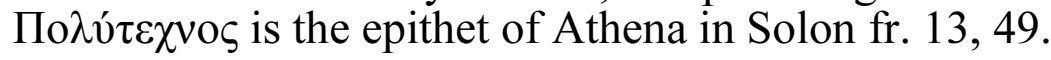


$\pi \mathrm{o} \lambda \hat{\mu} \mu \eta \tau 1 \zeta$ is not a corruption due to chance: authors who connect the verse with «hands» prefer «one of many works», whereas the authors who cite it in support of the allegorical interpretation of another famous mythical trickster Prometheus, prefer «one of great prudence». It is striking that both the etymology of $\chi \varepsilon i \tilde{p} \varepsilon \varsigma$ and the allegorical interpretation of the name Prometheus seem to be related with Prodicus' «utilitarian» theory of the origin of religion: $\chi \rho \tilde{\eta} \sigma ı$,

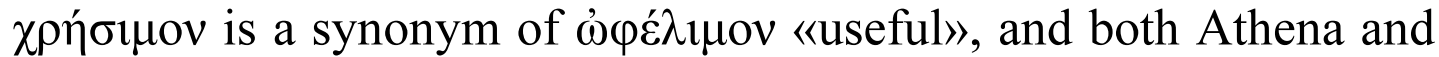

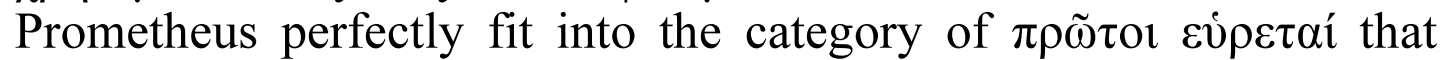
played important role in Prodicus' second stage. Since the interpretation of Zeus as «mind» is attested in PDerv, the chances are that Athena and Prometheus were mentioned in the lost parts of the papyrus.

The myth about Prometheus moulding ( $\pi \lambda \dot{\alpha} \tau \tau \varepsilon \imath$ ) man from clay is explained in Syncellus' source as an allegory of forming man by knowledge and reshaping him from apaideusia state to the state of paideia. Both Syncellus and a scholiast on Aeschylus $P V 120 \mathrm{~d}$ add to this allegory a quotation from the $\Sigma$ oøı $\sigma \tau \alpha$ í of Plato comicus (fr.

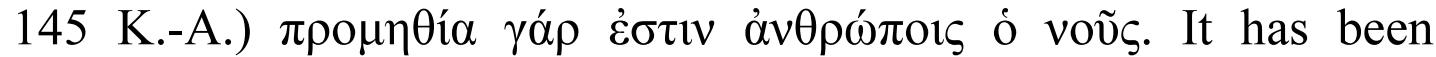
thought by some that the title «Sophists» refers to tragic poets and musicians only, but the evidence for this is weak ${ }^{86}$. The group of Sophistai mocked in the comedy may well have included both poets and sophists in the familiar sense, like Prodicus.

One puzzle remains unsolved: The verse about Athena as a 'master of many works', i. e. tekhnai, is very different from the verses of Orphic theogony quoted in PDerv.: it looks as a gnome or a verse from elegy rather than a fragment of epic mythical narrative. It is hard to imagine what might be its original context in a theogony. And even more puzzling is the fact that the author of this verse seems to share Prodicus' somewhat unholy explanation of traditional gods as personifications of «useful» tekhnai. Can it be a playful fabrication of Prodicus' himself?

Philochorus has been plausibly identified as the source of these quotations (Hussey 1999: 315). Dirk Obbink on independent grounds has plausibly argued that the Derveni papyrus was quoted

\footnotetext{
${ }^{86}$ The scholiast on Ar. Nub. 331a (= Plato com. fr. 149) commenting on

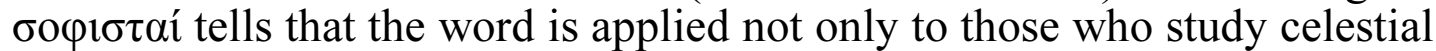

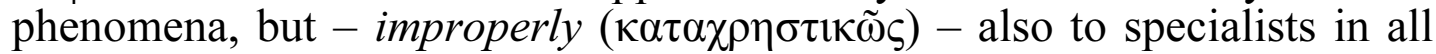
kinds of knowledge, even to a flute-player Bacchylides in Plato's «Sophistai». He does not tell that all Sophistai in this play were musicians like Bacchylides, on the contrary: he quotes Bacchylides as an extraordinary case.
} 
by Philochorus ${ }^{87}$. Objections to Obbink's thesis (Philochorus and the Derveni author may quote the same source independently) (Betegh 2006: 98-99, n. 20; Bremmer 2014: 65, n. 60) do not take into account Philochorus' general predilection for the rationalistic and «euhemeristic» interpretations of myth that can be best explained by the influence exerted on him by Prodicus' work on religion and

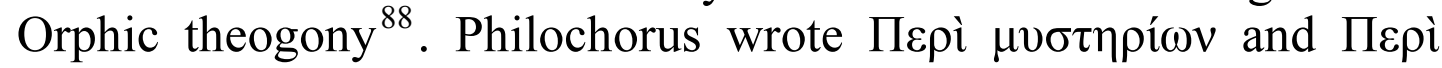
$\mu \alpha v \tau \imath \kappa \tilde{\eta} S$ in which he mentioned Orpheus and quoted two Orphic verses on prophecies ${ }^{89}$. Therefore he may well have consulted the influential work of Prodicus on the same subject. Besides that

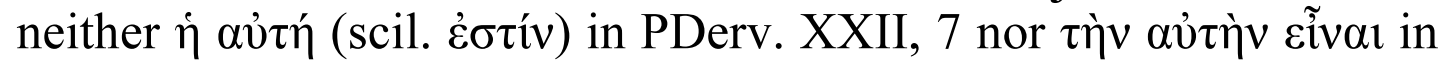
Philodemus is a part of the verse, i. e. of the supposed "common source». Unlike the names of the gods, it is in both cases a part of the commentary or a paraphrase and therefore reflects the linguistic preference of the commentator (which is the same). It is hard to imagine that the identity of the three goddesses was stated in a hymn

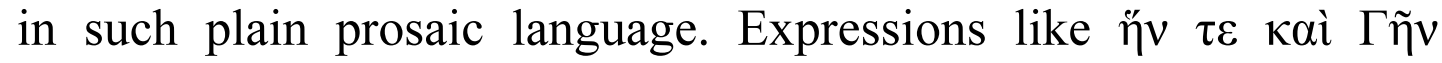
$\kappa a \lambda \varepsilon \dot{\varepsilon}$ ov $\sigma \mathrm{l}$ are conceivable or, alternatively, the same goddess was called by three different names in the invocation.

A striking sample of «linguistic archeology» reminiscent of PDerv is provided by Philochorus' rationalistic and naturalistic explanation of the names Tritopatores and Apollo: fr. 182 (verbatim

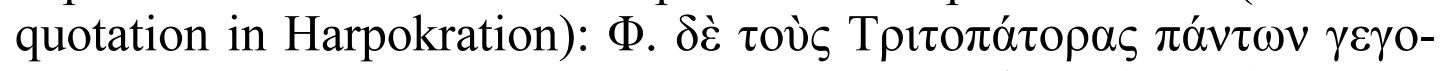

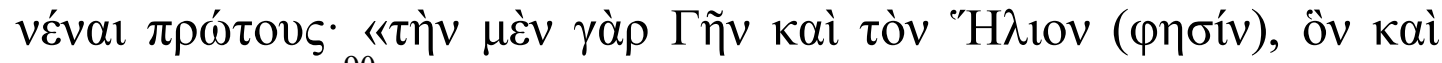

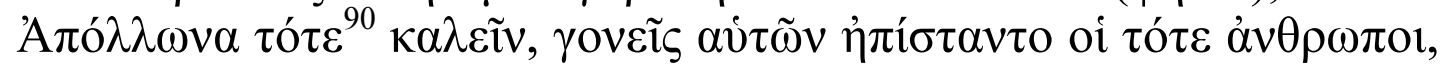

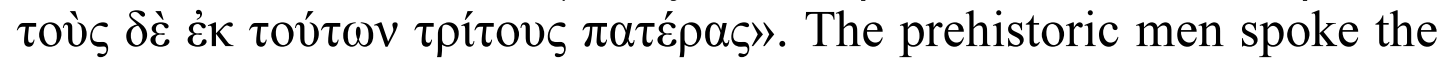
original natural language not yet corrupted by misunderstanding and correctly applied the name «Apollo» to the sun ${ }^{91}$.

(T13) According to Philodemus Epicurus exposed the atheistic views of Prodicus, Diagoras and Critias and accused them of «madness»; their method was that of «changing letters in the names of gods»: De pietate, pars I, col. 19, 11. 519-541 Obbink: ... $\alpha \rho \rho \alpha-$

${ }^{87}$ Obbink 1994: 110-135. FGrHist 328 F 185 compared with Philodem. PHerc.1428 col. vi 16-26 (= SVF II 1078).

88 The chances are that the collection of hymns quoted by Prodicus was no longer extant or available some 150 years later to Philochorus.

${ }^{89}$ FGrHist $328 \mathrm{~F} 77=$ OF 810 B. The fragment is odd: Orpheus speaks in the first person and boasts that his prophecies are infallible. A proem to a collection of $\chi \rho \eta \sigma \mu o i ́ ?$

${ }_{91}^{90}$ For no good reason Jacoby deletes $\tau$ ó $\tau \varepsilon$.

${ }^{91}$ On Orphic Physica and Tritopatores see Gagné 2007: 1-24; Bremmer 2014: 62 ff. 


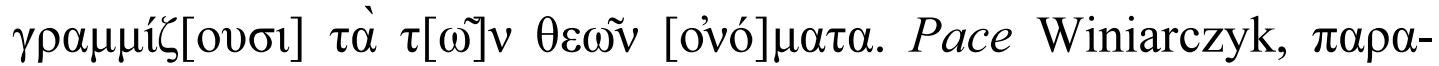
$\gamma \rho \alpha \mu \mu$ í $\varepsilon i v$ means 'to change, to alter letters' (with a connotation 'to distort', 'to falsify', by analogy with $\pi \alpha \rho \alpha \chi \alpha \rho \alpha ́ \tau \tau \varepsilon i v)$, not 'to rearrange ${ }^{92}$. The reference is apparently to the rationalistic etymologies based on the assonance between the divine name and its supposed etymon. Examples of this technique are found in PDerv. XXII,10

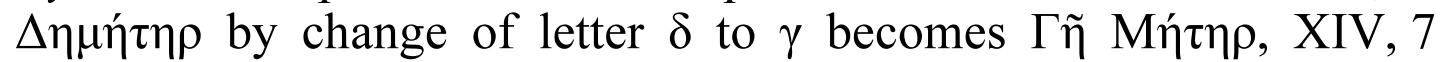

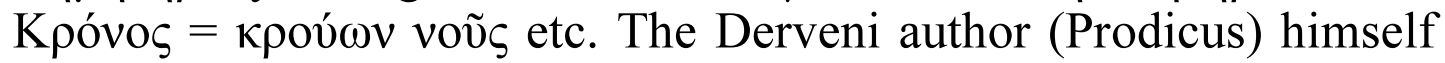
uses a similar expression in XXVI,11 $\gamma \rho \alpha \mu_{\mu} \mu \alpha \tau \alpha \pi \alpha \rho \alpha \kappa \lambda i ́ v o v \tau \alpha$ to describe the possible change of $\mu \eta \tau \rho$ ò $\varsigma \dot{\varepsilon} \tilde{\alpha} \varsigma$ to $\mu \eta \tau \rho$ ò $\varsigma$ غoĩo. The phrase $\mu 1 \kappa \rho o ̀ v ~ \pi \alpha \rho \alpha \kappa \lambda i v \omega$ 'alter slightly' exactly with the same meaning occurs in Plato's Crat. 400c (the change of only one letter in Orphic etymology $\sigma \tilde{\omega} \mu \alpha / \sigma \tilde{\eta} \mu \alpha$ ) and 410a (the Phrygian pronunciation of the word $\pi \tilde{v} \rho$ that «slightly deviates» from Greek $)^{93}$. Most of the etymologies of the divine names in Plato's Cratylus are based on the assonance between the name of a god and its etymon.

(T14) Galenus on several occasions (in four different treatises!) angrily rebukes Prodicus for using the term for phlegm $(\varphi \lambda \dot{\varepsilon} \gamma \mu \alpha)$ not in its commonly accepted sense of a cold and dense liquid in the body, but in the unusual sense of something «burnt» on the ground of its etymological derivation from $\varphi \lambda \varepsilon ́ \gamma \omega$ 'to burn'. (Prodic. fr. 63$65 \mathrm{M})$.

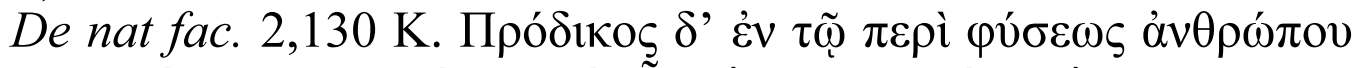

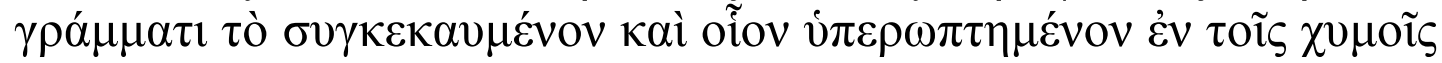

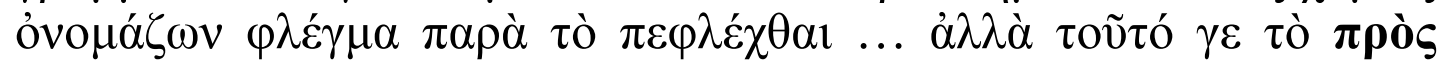

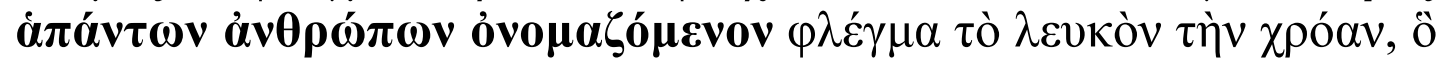

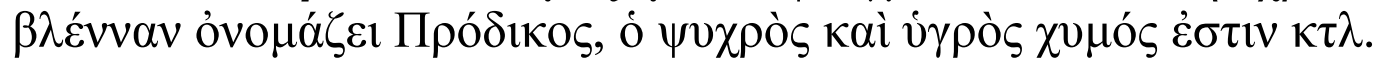

The unusual periphrastic expression «as it is called by all men» for «common name» according to the whole corpus TLG search does not occur elsewhere, except in another single passage of Galenus (v. 8, 74 K.), but it strikingly resembles the distinction between the «peculiar» expressions of Orpheus and the «spoken names», «which have been called by all men», $\alpha$ $\pi \alpha ́ v \tau \varepsilon \varsigma ~ \alpha ̋ v \theta \rho \omega \pi 01$

${ }^{92}$ LSD, s.v. $\pi \alpha \rho \alpha \gamma \rho \alpha \mu \mu i ́ \zeta \omega$ interpret the $\pi \alpha \rho \alpha \gamma \rho \alpha \mu \mu i ́ \zeta o v \sigma ı$ ỏvó $\mu \alpha \tau \alpha \theta \varepsilon \tilde{\omega} \nu$ in Philodemus passage as 'makes the gods nugatory' and mark this use as metaphorical. In our view the verb $\pi \alpha \rho \alpha \gamma \rho \alpha \mu \mu i \zeta \omega$ (variant $\pi \alpha \rho \alpha \gamma \rho \alpha \mu \mu \alpha-$ $\tau i \zeta \omega)$ has literal meaning 'to change or to distort letters', it is the result of such change that makes the gods nugatory and reduces them to trivial nonsacred things like food and drink, elements etc.

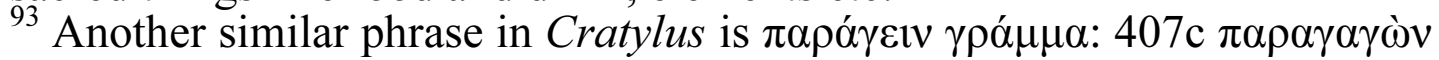

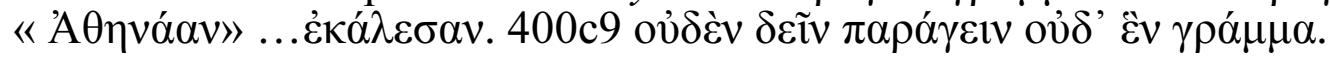


ỏvó $\mu \alpha \sigma \alpha v$ in PDerv, XVIII,8-9.

(T15) Another common feature of Prodicus and the Derveni author is the attention to synonyms and a similar phraseology in the semantic analysis. It might seeem prima facie that they follow different or even opposite procedures: Prodicus was renowned for his subtle distinctions of words (akribologia) with similar meaning, the Derveni author, on the contrary, lays emphasis on «the same

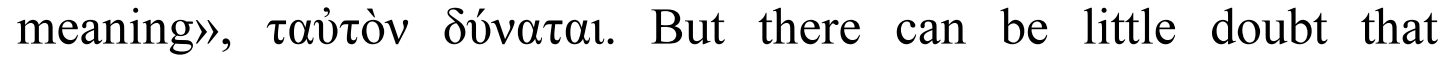
Prodicus mastered the art of his teacher Protagoras to argue «both

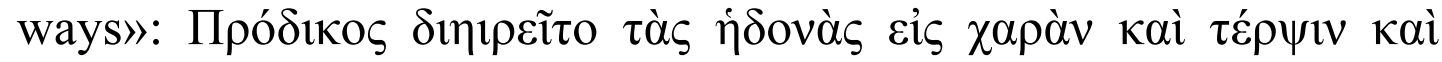

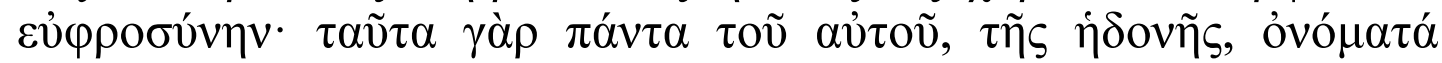

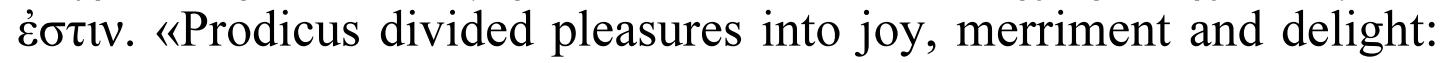
according to him all these are names of the same thing, i.e. of pleasure $^{94}$. Compare this triad of names with the triad $\lambda \varepsilon^{\prime} \gamma \varepsilon ı v$,

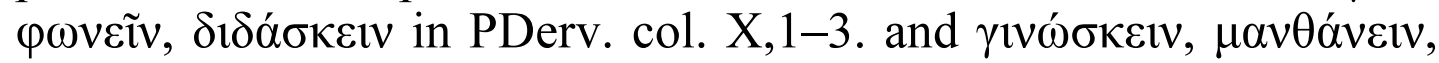
$\pi i \sigma \tau \varepsilon v i \varepsilon v$ in $\mathrm{V}, 9-12$. Although the author asserts ad hoc the

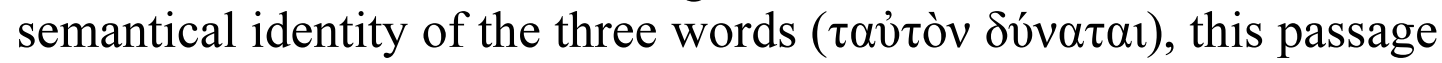
betrays a professional knowledge of synonyms. The two different procedures are best explained by the two different tasks: in his teaching of the general rhetoric Prodicus' aim was to teach students orthoepeia, the correct use of names based on the subtle semantical distinctions between synonyms. In the allegorical interpretation of the divine names his aim was exactly the reverse: the emphasis on «the same meaning» was imposed by the naturalistic monism and one-element theory of matter («everything is air»). Prodicus'

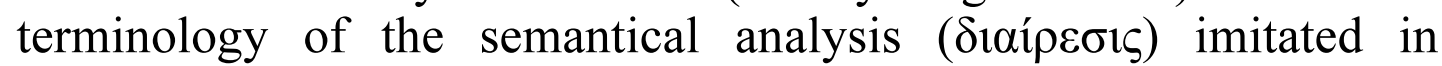
Plato's Protagoras 340a (= Prod. 50 M.) is very similar to the one

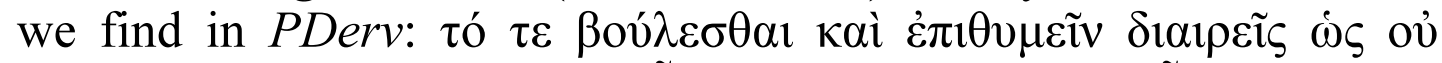

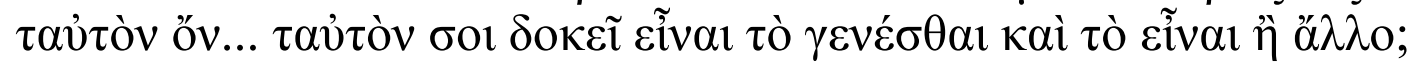

(T16) 'Y $\pi \varepsilon \rho \beta \alpha \tau o ́ v$ occurs in PDerv twice: in col. IV,10 in the authorial comments on Heraclitus' quotation, and in VIII,6 applied

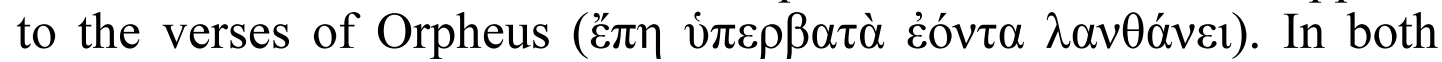
cases it is a rhetorical and grammatical term for the irregular wordorder, see for details section (4) below with notes 112-113. In both cases it is used to indicate the cause of the ambiguity of the next and the cause of misreadings. A third mention of hyperbaton is probably

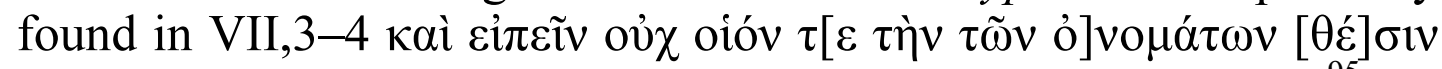
«and it is impossible to determine the position of names.»" ${ }^{95} \mathrm{By}$

${ }_{95}^{94}$ Arist.Top. $112 \mathrm{~b} 22 \mathrm{ff} .=$ Prodicus T47 M.

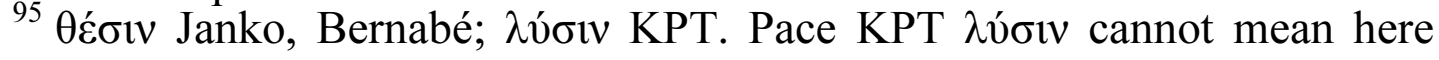




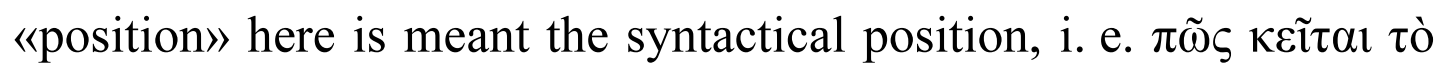
övo $\mu \alpha$, i. e. whether it should be taken with what precedes or with what follows, as in the case with the word aidoĩov. Hyperbaton is an exegetical tool that Protagoras, the teacher and friend of Prodicus, used in his interpretation of the poetic texts (Plato, Prot. 343

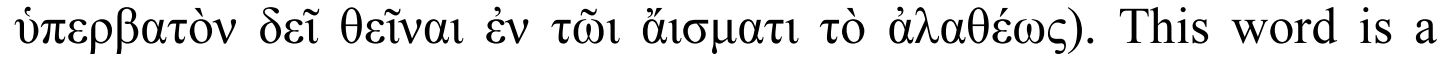
hapax in Plato and since Plato puts it into the mouth of Protagoras, it may well be an authentic term of the sophistic hermeneutics. Plato probably looked with suspicion at this technique since it could easily be used for «sophistry»: the substitution of a «penis» for a «venerable god» in PDerv VIII,6 by admitting a hyperbaton is a case at point.

(T17) In the Ionian dialect of Ceos (group of the Central Ionian) Atticisms are attested in the last quarter of the fifth century B.C ${ }^{96}$. This perfectly agrees with the dialect of the Derveni papyrus which Tsantsanoglou describes as «an Ionic text liberally sprinkled with Atic features», Willi defines it as «a curious mixture of Attic and Ionic ${ }^{97}$.

(T18) We do not exclude that one of the sources of the physical allegoresis of Orphic theogony in [Clem.Rom.] Recogn. 6 may be PDerv., especially in view of the reduction of Olympian gods to

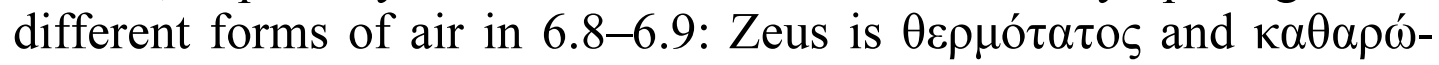
$\tau \alpha \tau$ o $\alpha i \theta \eta \dot{\eta} \rho$, Hera is the sublunar $\alpha \dot{\eta} \rho$ which is not so clean, her

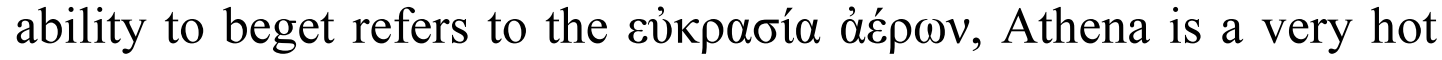
air ("丷к $\rho \omega \varsigma \theta \varepsilon \rho \mu o ́ v)$ which is unable to generate something, hence the myth that she is a virgin; Artemis is the lowest part air which is extremely cold, hence the similar myth of virginity. The name of Dionysos refers to the exhalations upwards and downwards (a

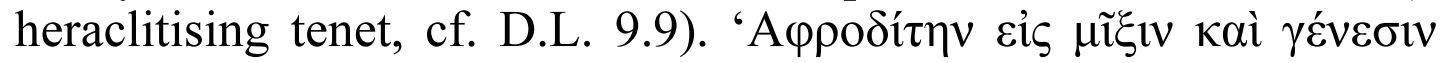

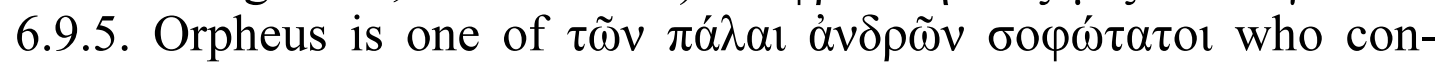
cealed the true knowledge of the divine from the unworthy in the form of myth: Kronos has never castrated Ouranos, Zeus has never seized royal power from Kronos, has never swallowed Metis and has never given birth to Athena from his head and Dionysos from his

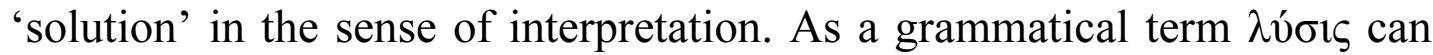
only mean 'looseness', i. e. asyndeton, LSJ II, 4,f but this does not fit the context because asyndeton is always obvious. Demetrius, following Aristotle, explained the obscurity of Heraclitus by lysis: Demetr. De eloc.191

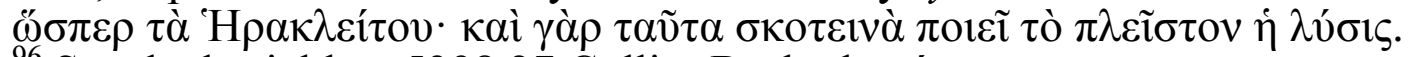

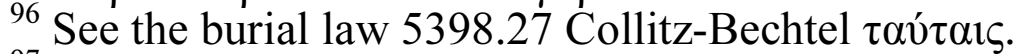

${ }^{97}$ KPT (2006) 11-14; Similarly West (1983) 77 and note 11; Willi (2010) 114. On the dialect see also Bremmer (2014) 64.
} 
thigh etc. (6.2.). All mythology is a result of a misreading of Orpheus' text.

$(\mathrm{T} 19)=$ section $(5)$ below.

(4) The text and interpretation of PDerv col. $I^{98}$

In establishing the text of col. IV and in their commentary KPT (p. $148 \mathrm{ff}$.) move in the right direction when they supply $\tau \dot{\alpha} \xi \mathrm{g} v$ in

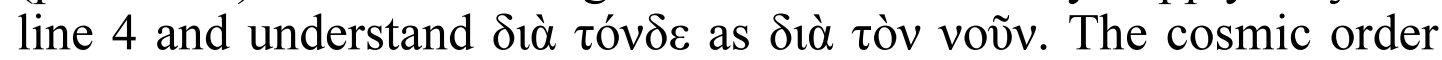
results from the action of the cosmic mind (=Zeus). But almost all other supplements in col. IV are call for serious doubts since they

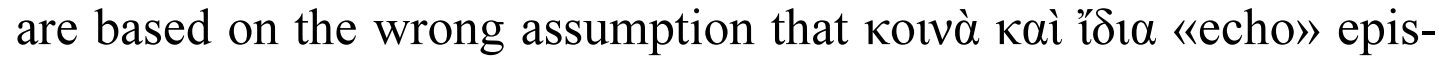
temological terms of Heraclitus as well as on the outdated physicalist interpretation of the so called "cosmic measures» in Heraclitus. Kouremenos (KPT, p.55) explains: «If $\tau \grave{\alpha}$ кoıvó and $\tau \grave{\alpha}$

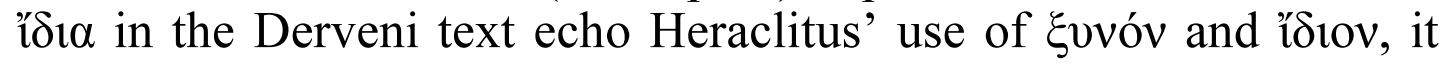
can be plausibly assumed that $\tau \grave{\alpha}$ kovvó are the truths revealed by Heraclitus' everlastingly true account ... whereas $\tau \dot{\alpha}$ ' $i \delta 1 \alpha$ are the false beliefs held by uncomprehending people». The following objections can be raised against this assumption and interpretation. 1) The opposition of «private and common» and the collocation of

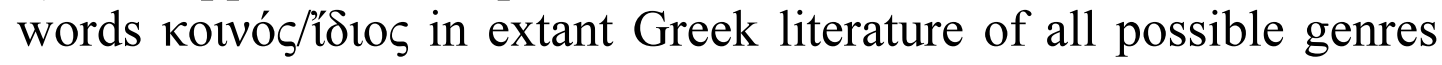
are very common, as are other most common and non-specific oppositions like «good and bad», «big and small» etc. To postulate «echoes» of one text in another on the ground of «coincidence» of such common and non-specific words is methodologically questionable. A $T L G$ proximity search for $\operatorname{\kappa otv}(\operatorname{os} \varsigma)$ and i $\delta 1(0 \varsigma)$ within 5 lines for the period from the beginning to the end of 2 nd century A.D. (Pre-Patristic and Pre-Neoplatonic) yields 1077 instances. Only one of this is found in a doxographicum related with Heraclitus (Sext. Emp. 9. 133), in the overwhelming majority of cases the reference is to the "common» vs. «private» or "one's own» vs. "common» with no relation whatsoever to metaphysics or epistemology. In other words, the probability that the occurence of the opposition kouvó $/$ 't $\delta 10 \varsigma$ in any text «echoes» Heraclitus' usage is less than one in a thousand. 2) Heraclitus never uses the forms pl.

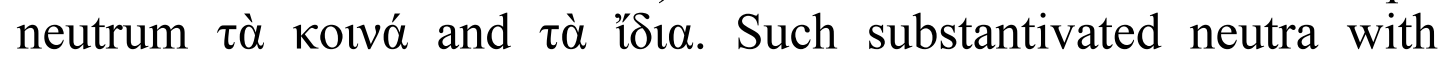
article are not typical for Heraclitus' archaic and poetic prose. Even on formal linguistic grounds such language is unlikely in Heraclitus: he uses article only in rare cases and he regularly omits it when he

\footnotetext{
${ }^{98}$ This section supercedes the text and interpretation in Lebedev (1989 $)$, although the basic approach to koina/idia and to the general meaning of Heraclitus' fragment remain the same.
} 
speaks about the phenomenal opposites (Lebedev 2014: 53). 3) Such terminology in Heraclitus is unlikely not only on linguistic, but also

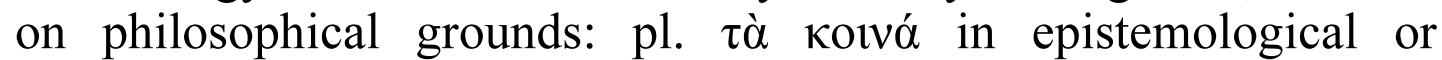

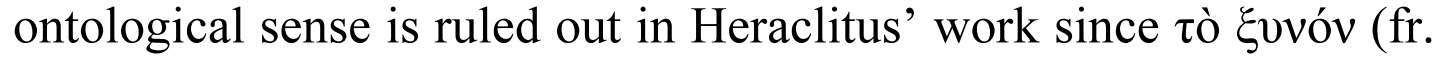
$133 \mathrm{~L} / \mathrm{B} 114$ ) is one by definition and is opposed to «many». Evvòs $\lambda$ ófo $\zeta$ is the only one true logos and is opposed to many false logoi

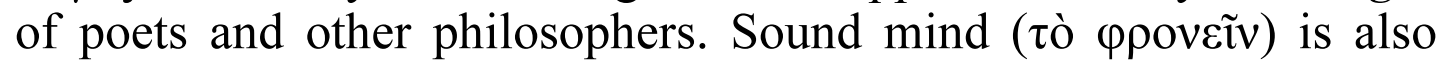

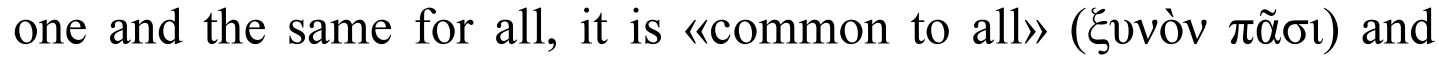
opposed to the plurality of imaginary worlds of dreamers and poets. Heraclitus' authentic word for «false beliefs» or subjective opinions

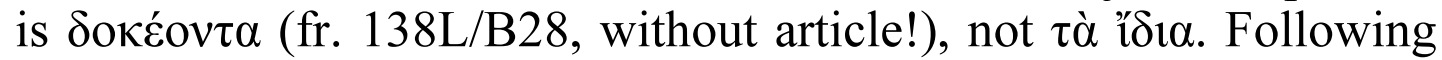
this false assumption, KPT try to supplement verbs that would

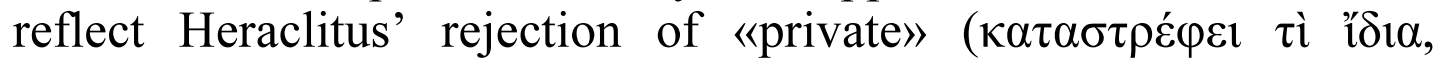

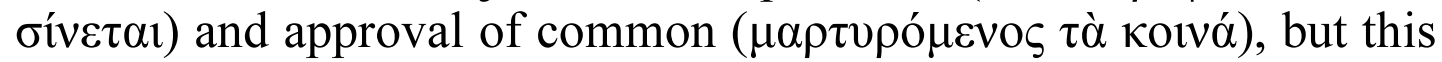

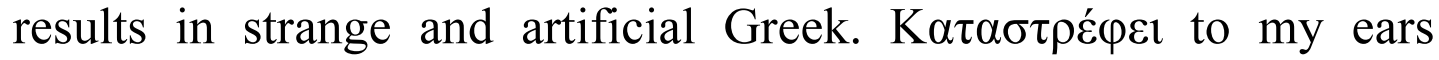
sounds modern Greek. In modern Greek this (very popular) verb can be used in a wide variety of contexts not confined to physical

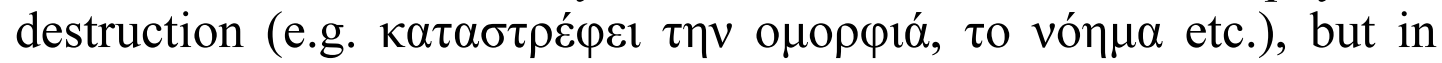
classical Greek it is used predominantly in military contexts and has a literal meaning of ruining, destroying a city, of «setting upside down». We could not find in lexica or through TLG searches a single instance of this verb in grammatical, rhetorical context, it simply does not convey the notion of «rejection», «avoiding» etc. The same a fortiori can be said about the verb oivetal which is used exclusively of physical violence, looting, plundering, damaging property etc. Such verbs could not be used by a literary critic in a stylistic analysis and could not be used by a commentator as descriptions of what Heraclitus was doing either in his life or in his

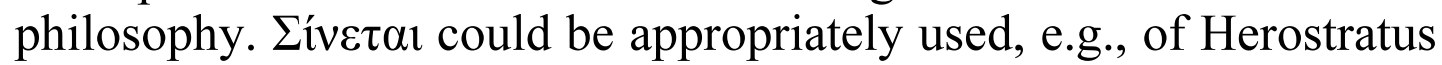
setting on fire the Artemision. The only possibility to make sense of

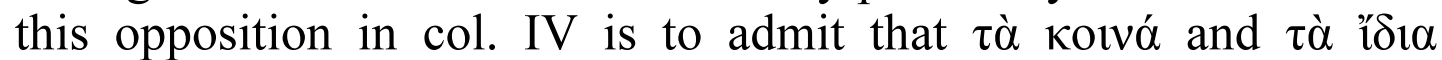
«common and peculiar names» are rhetorical terms of the Derveni commentator himself with óvó $\mu \alpha \tau \alpha$ or $\dot{j} \mu \alpha \tau \alpha$ implied: the «common names» are plain words of the ordinary language that are in common usage and have a transparent meaning intelligible to everybody; they are the same as «spoken and (commonly) recog-

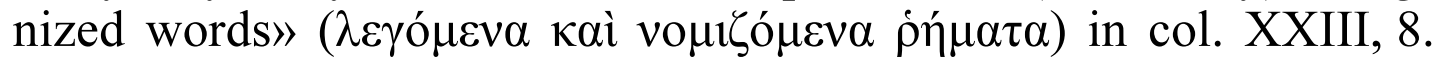

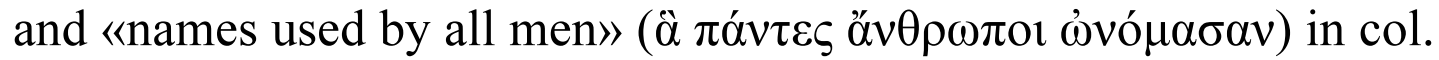
XVIII, 8-9. The «Peculiar» names are poetic metaphors and divine names whose meaning escapes the understanding of hoi polloi and requires a sophistic art of interpretation. Common words existed in the beginning before the «peculiar» ones, peculiar words seem to be 
a later invention of poets like Orpheus. This can be inferred from the col. XVIII according to which Orpheus metaphorically applied an already existing common name $\mu$ oĩp $\alpha$ «part» both to the wind (of

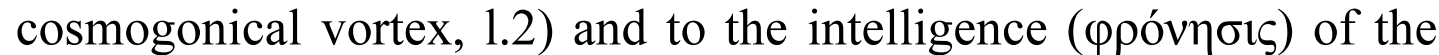

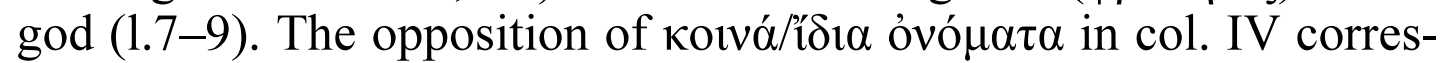

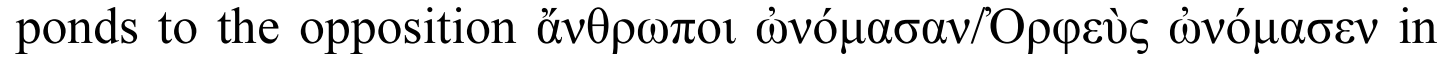
col. XVIII. The distinction between earlier «common names» and later «peculiar» names recalls the distinction between «first» and «second» names in Plato's Cratylus (see section 2 with note 23 above). Plato may have borrowed this distinction from Prodicus. The time when only «common» names were in use probably corresponds to the original phase of civilization discussed in Protagoras'

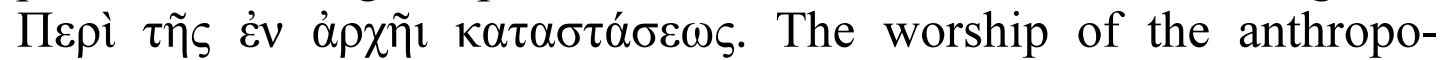
morphic gods of the official Greek religion at that time could not exist since the names of the gods had not yet been invented by poets. Humans living in that time either were natural atheists or worshipped the natural phenomena, «things that really exist» ( $\tau \dot{\alpha}$ દ́óv $\tau \alpha, \tau \alpha \grave{\alpha} \pi \rho \alpha ́ \gamma \mu \alpha \tau \alpha)$, like the stars and the elements, and first of all

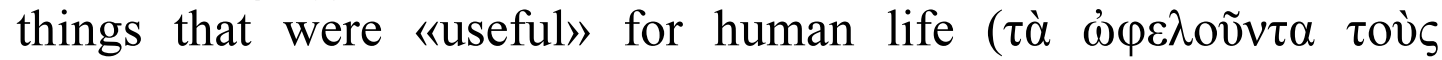
$\dot{\alpha} v \theta \rho \omega ́ \pi 0 v \varsigma)$, like the sun and the moon. The false mythological religion of poets was the result of the subsequent "disease of language», of the misreading and misunderstanding of Orpheus' poetic cosmogony by the ignorant polloi.

Both Orpheus and Heraclitus, according to the Derveni author, use «idiomatic» cryptic language to convey to «those who understand correctly» similar philosophical ideas (in this case on cosmic mind producing cosmic order) and at the same time to conceal these ideas from «the many». It becomes clear that in this case the subject of $\mu \varepsilon \tau \alpha \theta \varepsilon \dot{\varepsilon} \mu \varepsilon v o \zeta$ is also Heraclitus (and not Zeus or cosmic mind) and that the object of this verb is again óvó $\mu \alpha \tau \alpha$.

The term $\mu \varepsilon \tau \alpha \varphi$ op for what we call metaphor, is not attested in poetics and rhetorics before Isocrates, Anaximenes of Lampsacus and Aristotle in $4^{\text {th }}$ century B.C. But words and concepts are not the same thing, so it does not follow that $5^{\text {th }}$ century Sophists had no idea about metaphorical language. We have good reasons to suppose that í $\delta 10 v$ óvo $\mu \alpha$ or $\tau \dot{\alpha} i \delta i \alpha$ $\zeta o v \tau \alpha$ was one of the early ( $5^{\text {th }}$ cent. B.C.) terms for metaphor ${ }^{99}$. The $5^{\text {th }}$ century usage was still followed by Epigenes in his allegorical interpretations of «Orpheus' poetry»:

99 This usage is semantically related with the grammatical term i $\delta i \omega \mu \alpha$ (peculiarities of style, idiomatic expressions, LSJ, s.v.II) and common

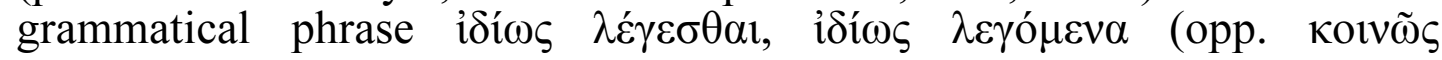




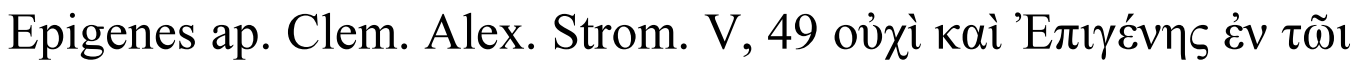

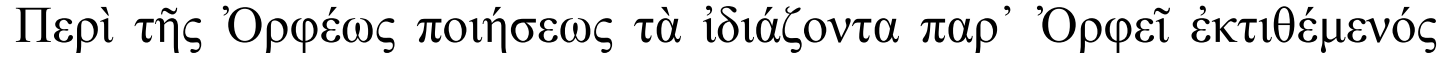

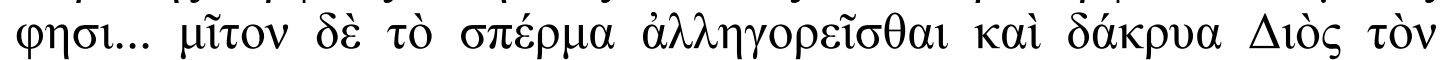

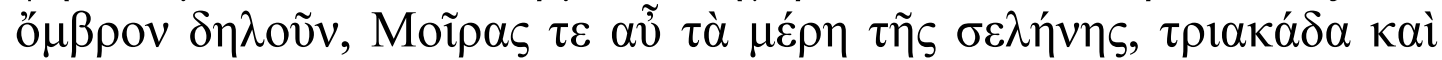

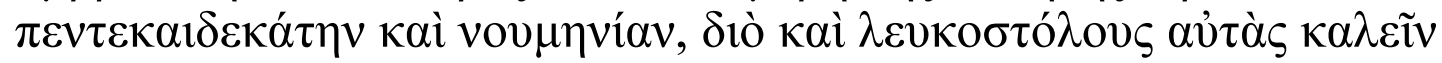

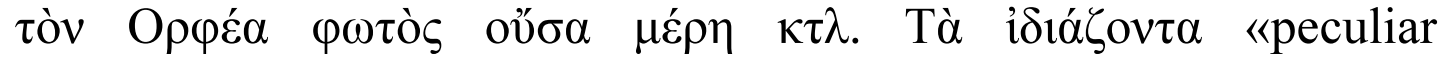
expressions» as a term for poetic metaphors is not a part of Clement's own lexicon, it occurs only once in a quotation from Epigenes and therefore most probably belongs to Epigenes. The Derveni author also conveys the concept of metaphorical language

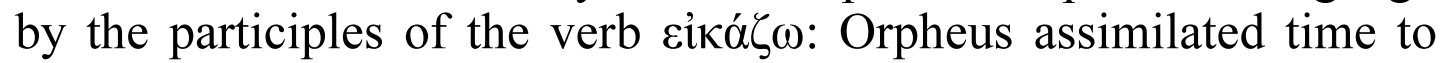

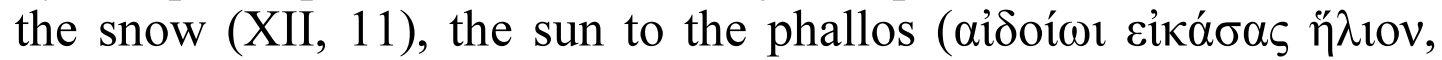

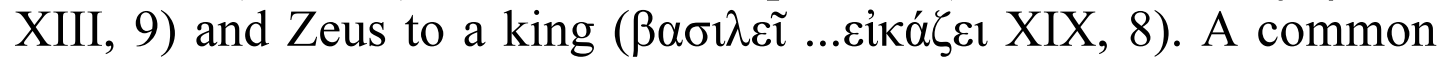
name becomes metaphorical («peculiar») be re-attaching it

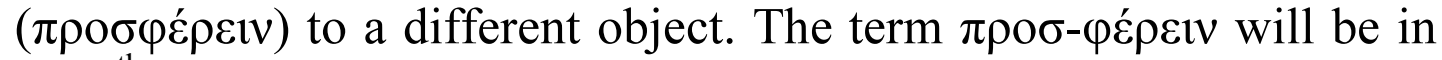
the $4^{\text {th }}$ century changed to $\mu \varepsilon \tau \alpha-\varphi \varepsilon ́ \rho \varepsilon i v$.

Scholars who attempted to restore the text of the Heraclitus quotation have often been misguided by the long ago antiquated physicalist approach to Heraclitus's philosophy in the tradition of Kirk-Marcovich that derives from Burnet (1892) and Karl Reinhardt (1916). Scholars of this trend dogmatically denied the authenticity of the world-conflagration (ekpyrosis) in Heraclitus regarding it as a Stoic distortion of the alleged theory of «cosmic measures» which, as we are told, emphasised stability rather than change: the dynamic cosmic cycle of Heraclitus' unanimously recognised by all ancient readers of his book, has been replaced by a trivial «meteorological» regular changes (like day and night) in a stable eternal cosmos. Since the cyclical cosmogony is firmly linked with the notions of Time and Fate, they rejected the Universal Flux as Plato's invention (another imaginary «projection») and interpreted the image of the cosmogonical god of Time (Aion) as a trivial saying on human fortune. The authentic verbatim fragment of Heraclitus on Fate has been wrongly relegated to Spuria already by Diels. ${ }^{100}$ The days

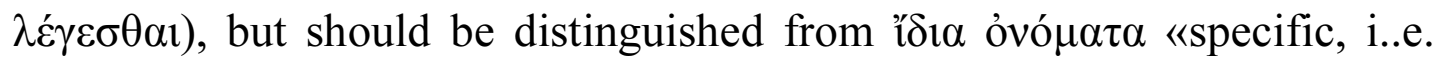
appropriate» words in Plato (R. 580e) and Aristotle (Rhet.1407a31), as well as from the logical term $\tau$ ò ícov for specific or essential feature in Aristotle and the Stoics, on which see Reesor (1983). Exact parallel to

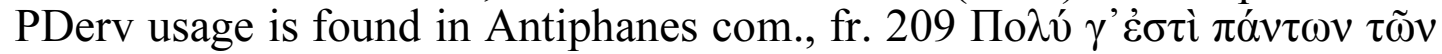

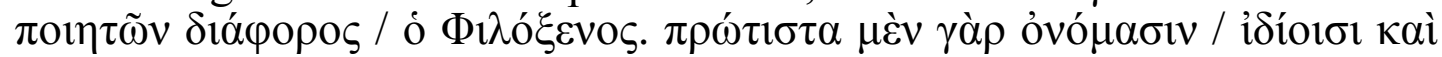

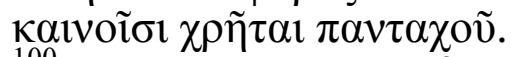

${ }_{100} 22 \mathrm{~B} 137 \mathrm{DK}=$ fr. 53 Lebedev. We defend its authenticity in the commentary to our edition, pp. 362-364 and restore the text as follows: 
when such approach to Heraclitus was dominant have passed. Charles Kahn was right when he remarked that «Stoics are the true Heracliteans of antiquity» and when in his criticism of Burnet he emphasised that if there was any theory of cosmic «measures» in Heraclitus, it was a theory of «measure or equality preserved over time» in a diachronically structured pattern. ${ }^{101}$ We have on many occasions criticised and refuted the physicalist interpretation of Heraclitus. Both the theory of the universal change and of periodic ekpyrosis, as well as the idea of Fate and dynamic cosmogony rather than static cosmology are genuine doctrines of Heraclitus attested both by his ipsissima verba and by impressive consensus of independent ancient readers (first of all by Aristotle and the Stoics) (see Lebedev 1985; 2014; 2017). The precise analysis of Heraclitus' metaphorical language leaves no doubt that in fr. 42L/B 90 he speaks of the dynamic process of the alternation and interchange ( $\dot{\alpha} v \tau \alpha \mu \varepsilon i \beta \varepsilon \tau \alpha 1$, and not a static $\dot{\alpha} v \tau \alpha \mu$ or $\beta \eta \dot{~ i s ~ t h e ~ r e a d i n g ~ o f ~ a l l ~}$ manucripts of Plutarch) of «all things» and «fire». Burnet's interpretation of the «cosmic measures» in Heraclitus as a kind of quanta of matter or stable «aggregate bulk of every form of matter» (Burnet 1920 : 150) was based on a shaky foundation from the start; the text of PDerv. col. IV provides an additional refutation of this $19^{\text {th }}$ century invention typical for the epoch of hypercriticism and "suspicious scholarship" (Parker).

Formal papyrological considerations and restrictions imposed by them are no doubt very important in our case as in any other restoration of a papyrus text. However, although necessary, they are not sufficient. Any attempt of the restoration of the original text of Heraclitus quotation in col. IV that ignores the general purpose of Heraclitus' book and pays no attention to the original context of the Sun fragment is doomed to failure. All supplements and interpretations proposed hitherto that focus on the size of the sun and understand the «limits» with reference to the size of solar disk are

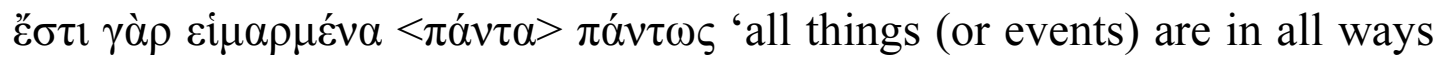
determined by fate'. Stobaeus is an excellent and trustworthy source; $\gamma \rho \alpha ́ \varphi \varepsilon \imath$ indicates a verbatim quotation. Diels dismissed it with a surprising dogmatic verdict: «Zitate Heraklits gibt es in Placita nicht». The Derveni papyrus has demonstrated how wishful and wrong was Diels: the doxa on the size of the sun is a verbatim quotation with a transposition of only one word. Ei $\mu \alpha \rho \mu \varepsilon ́ v \alpha$ is found already in Theognis 1033 and need not be a

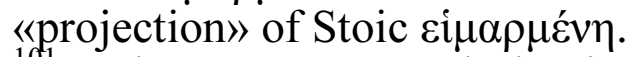

${ }^{101}$ Kahn 1981: 5; and the important «Excursus I: On the traditional interpretations of the cosmic cycle» in Kahn 1981: 147-153. 
misguided by Burnet-Kirk-Marcovich physicalist approach to Heraclitus. Heraclitus was not a scientist, nay he attacked the Milesian mechanistic vortex cosmogony as absurdity refuted by the beautiful harmony of the cosmos (fr. 38L/B 124). The cosmic order and harmony point to the existence of a providential cosmic Mind (Gnome) that «steers» the whole Universe (fr. 140L/B 41). Of the

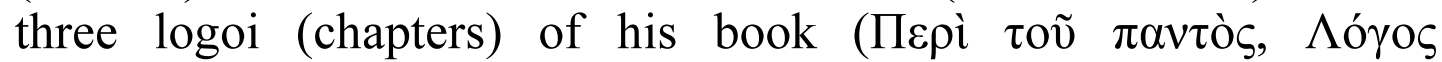

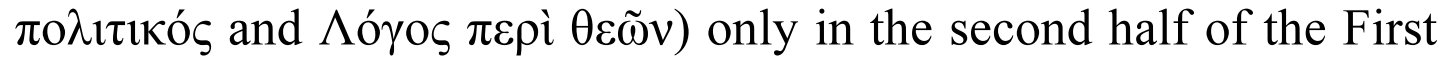
logos cosmos and natural phenomena were discussed: this amounts to about $1 / 6$ or so of the total text. But even this «cosmological» section had little in common with the contents of a standard Ionian Peri physeos. There is not a single authentic (quoted verbatim in Ionian dialect) fragment of Heraclitus that contains an etiological explanation of natural phenomena typical for the Ionian physikoi. Theophrastus could not find in Heraclitus work a consistent physical theory and attributed the contradictions to his melancholia. Instead of a unified scientific physical theory (like that of Anaximenes or Anaxagoras) we find in the extant fragments a plurality of poetical metaphorical models of the cosmos ${ }^{102}$ : cosmos as liber naturae ( $\lambda$ ó $\gamma \circ \varsigma$ ö $\delta \varepsilon$ ), cosmos as templum naturae (from which the sacral metaphor of $\pi \tilde{u} \rho \dot{\alpha} \varepsilon i ́ \zeta(\omega 10 v$ derives), cosmos as a stadion with comic race ( $\dot{\varepsilon} v \alpha v \tau 10 \delta \rho o \mu$ í $\alpha$ ) of opposite forces, cosmos as a battlefield in which the 4 world masses (Pyr, Prester $=$ Wind/Air, Sea and Earth) are engaged (fr. 44-45L/B 31), winning an losing in turn at the predestinated by fate «measured» periods of time, cosmic cycle as a pesseia game conducted by the divine child Aion (fr. 33L/B 52) etc. Most of these metaphorical models present a diachronically, and not spatially (geometrically) structured pattern of the «road up and

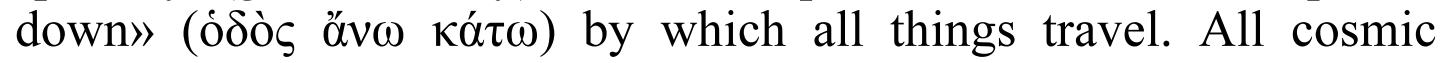
phenomena, including the elements and stars, incessantly move from a minimum to a maximum («way up») and backwards («way down») in a kind of a sway of pendulum. It is from this section of Heraclitus' book, from a series of empirical «proofs» (tekmeria) of the universal «divine law» of regular «reversals» (tropai, amoibai) of opposite forces that the Derveni fragment of Heraclitus about the sun derives. Fr. 55L/B120 which in our edition immediately precedes the Derveni quotation from Heraclitus (fr. 56L), speaks about the «turning posts» ( $\left.\varepsilon_{\varepsilon} \rho \mu \alpha \tau\right)$ of the Morning and Evening and identifies one of this points with oũpos aïpíov $\Delta$ iós, «the limit of (the period) of clear Zeus (= Sky)», i. e. with the autumnal

${ }^{102}$ I argue for this in extenso in Lebedev 2014: 59-90. 
equinox» (Lebedev 1985; 2014: 368-373). And the Oxyrrhynchus fragment on the moon $(60 \mathrm{~L})$ that follows soon after the Derveni fragment speaks about the number of days (fourteen), i. e. again about the time, not about size. The Hippocratic author of De diaeta I summarizes Heraclitus' theory of the cosmic change with more precision and accuracy than Plato in his «universal flux» passages in Theaetetus and Cratylus ${ }^{103}$. It is to these temporal limits and «turning points» of the «way up and down» (increase and diminution), and not to the size of stars and material masses that Heraclitus applies in extant authentic fragments the term ópor synonymous with $\tau \varepsilon \dot{\varepsilon} \rho \alpha \tau \alpha$ 'turning posts', $\tau \rho \circ \pi \alpha i$ ('turns' like those of a wheel),

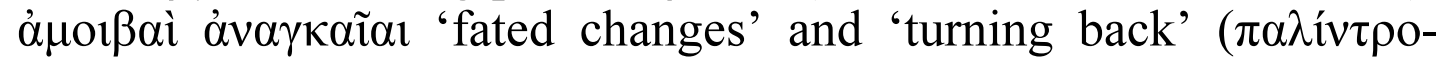
$\pi \mathrm{O} \varsigma$ ). Therefore in the quotation in col. IV ópous refers to the 'fixed terms' of the year-cycle, i. e. to the Summer and Winter Solstices ( $\tau \rho \circ \pi \alpha i \dot{\eta} \dot{\eta}$ íov) that the sun will «never exceed». The mention of the «fixed month» ( $\mu \eta v i$ i $\tau \alpha \tau \tilde{\omega} \imath$ ) in IV,13 makes this interpretation certain (see our commentary on this line below). The regular change (increase and diminution) of all cosmic phenomena is not due to chance, the temporal «limits» are set by a divine Supervisor and

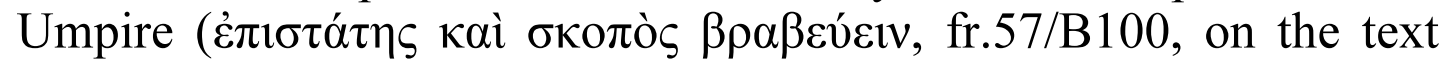
see Lebedev 1985), the supreme ruler of the Universe represented in the current cosmological phase by the Sun, the remnant of the original pyr aeizoon. In Heraclitus' mythopoetical Universe the sun is not a «celestial body» like an «ignited lump» of iron in Anaxagoras, it is a living god imbued with a mind and probably identified with Apollo (fr. Probabilia 12-13 Leb.). «Being the size of a human foot» is a rhetorical phrase that emphasises the modesty of an ideal monarch: the sun is «tiny» in size when compared with the huge cosmic masses of the Air (Prester), the Sea and the Earth, and yet he rules over all of them because he is the mind of the Universe. The supreme cosmic god is the size of man's foot: this is a political and theological rhetoric, and not a physical science ${ }^{104}$. The

${ }^{103}$ However, contra Reinhardt, Kirk, Marcovich and their modern followers, the theory of the universal change was a genuine doctrine of Heraclitus. It was not invented by Plato since it is attested in earlier independent sources, such as De diaeta I and in ancient Sophists. Why would Plato ascribe to Heraclitus, Protagoras and poets a theory which he invented himself? The Derveni papyrus has proved that ancient Sophists indeed studied and quoted Heraclitus. There can be no doubt that Protagoras did so before his disciple Prodicus.

${ }^{104}$ The doxographers, hunting for rare doxai, wishfully torn out the phrase about the sun from the theological-political context and placed it in the

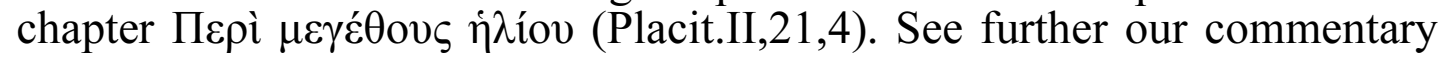




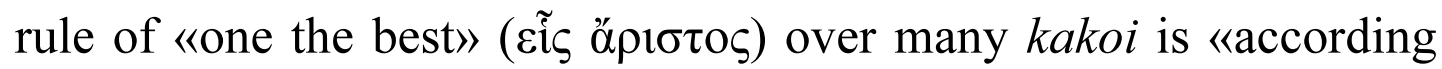

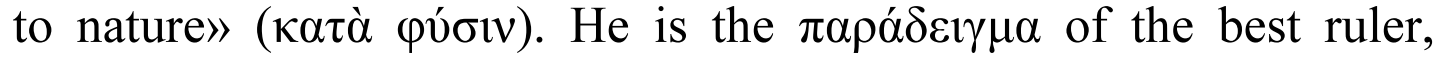
because he strictly obeys the $\theta \varepsilon i \pi o s$ vó

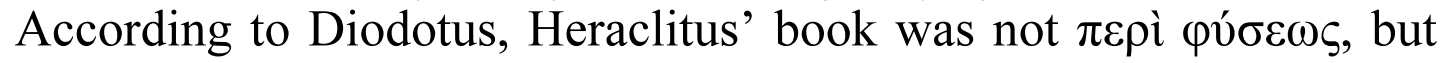

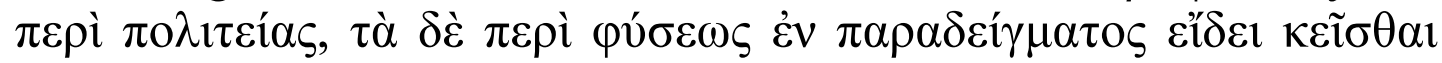
(D.L.9.15). Heraclitus points to the «paradigmatic» form of government in the polis of Zeus (monarchy of the Sun) in order to demonstrate that the popular rule (the rule of «many») is unnatural. And the law-abiding monarch is at the same time counterposed to the tyrant ${ }^{105}$. The clause on Erinyes in Heraclitus' fragment is a rhetorical circumlocution (imitating the style of Loxias' oracles) for «because the Sun is bound by the unbreakable horkos» where «horkos» is an archaic metaphor for the law of the cosmos aka the «divine law» of the Universe in fr. 131L/B 114. The peculiar function of Erinyes was to punish those who commit perjury

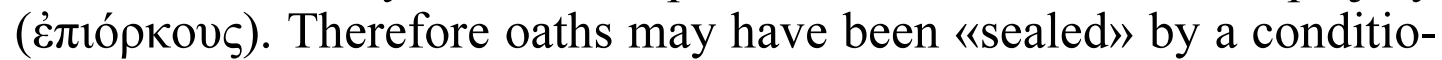
nal curse: «if I break the oath, let the Erinyes, ministers of Justice, find me out and seize me!». Cf. the "decree of Ananke sealed by wide oaths (öрко1૬)», i. e. the divine law of transmigration in Empedocles B 115. As in Heraclitus, cosmic «oaths» determine the fixed periods of time. Additional confirmation of this interpretation seems to be provided by the $\S 9$ of Janko's text where ő

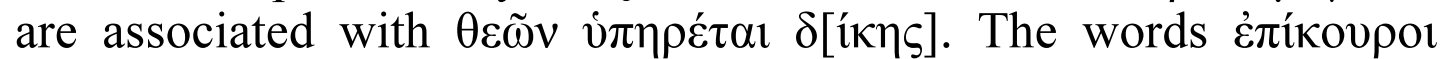
'ministers' and $\dot{\pi} \eta \rho \varepsilon ́ \tau \alpha 1$ 'servants' are synonymous.

Having in mind these considerations we propose the following reconstruction of the text of col. IV:

Papyrus Derveni, col. IV, 5-10. 12-13:

$[$.$\} ov \varepsilon .[\theta] \varepsilon \tilde{\omega} v[$

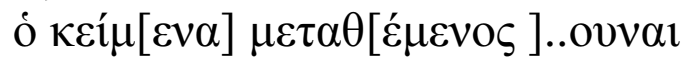

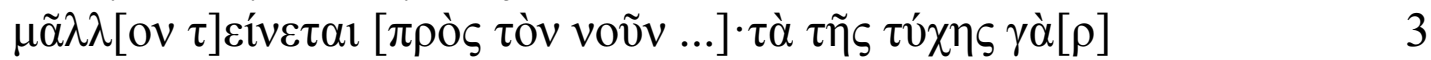

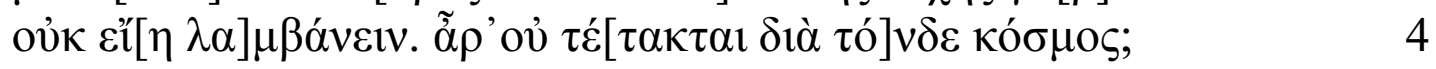

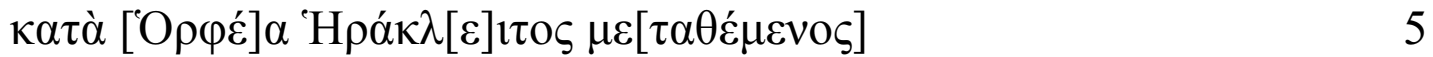

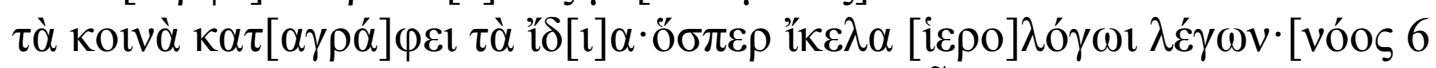

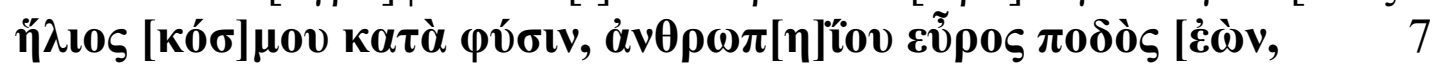

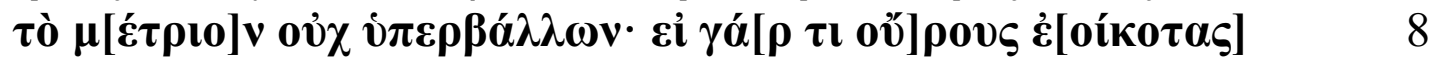

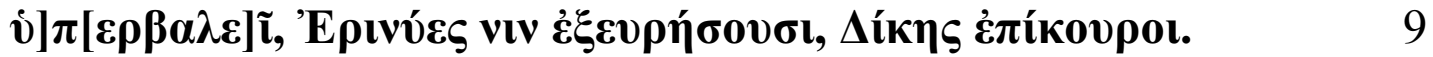

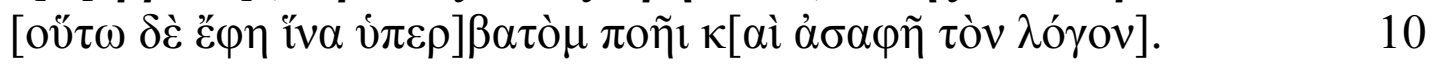

on line 8 below.

${ }^{105}$ Heraclitus attacks the popular rule in fr. 130L/B 104 and the hybris of the tyrany in $135 \mathrm{~L} / \mathrm{B} 43$. Praise for the monarchy and the rule of the one: fr. $128 \mathrm{~L} / \mathrm{B} 49$ and $132 \mathrm{~L} / \mathrm{B} 33$ et passim. 


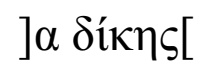

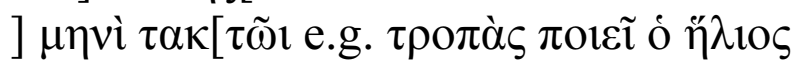

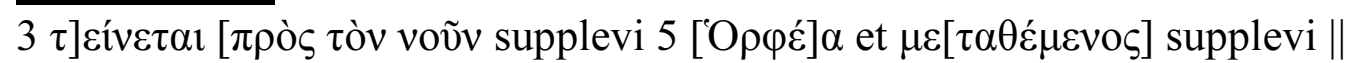

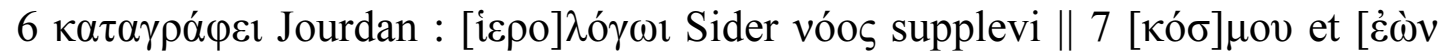
Lebedev $1989: 39 \| 8$ oúpov]ৎ et $\dot{\varepsilon}[$ oıкó $\alpha \alpha] \varsigma$ Tsantsanoglou $\| 9 \dot{v}] \pi[\varepsilon \rho \beta \alpha \lambda \varepsilon] \tilde{\imath}$

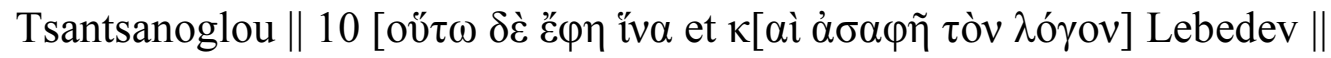

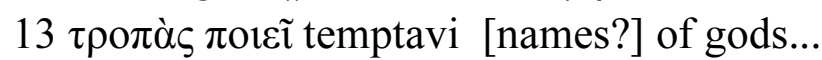

'... he [scil. Orpheus] changes the established names ... [the name of Zeus] rather alludes to the mind since

it would be impossible to understand [the origin of cosmos] as something due to chance. Isn't the cosmos set in order by the mind? In accord with Orpheus Heraclitus [also] changes the common names and uses in his writings peculiar expressions. Speaking similarly to the author of hieros logos, he says: «the Sun is the mind of the cosmos by nature, being one man's foot in width and not exceeding the set limits. For if he does exceed the appropriate limits, Erinyes, the ministers of Justice will find him out.» He said so in order to make his speech obscure and based on inverse word-order (hyperbaton)...justice... the sun makes reversals (= solstices) in a fixed month'.

1.2 o $\kappa \varepsilon i ́ \mu[\varepsilon v \alpha] \mu \varepsilon \tau \alpha \theta[\varepsilon \dot{\varepsilon} \mu \varepsilon v o \varsigma$ The subject of $\mu \varepsilon \tau \alpha \theta \varepsilon \dot{\varepsilon} \mu \varepsilon v o \varsigma$ (or any other verb with similar semantics) is Heraclitus, not a mysterious «one of the gods» (pace KPT, 129) or Nous (in the commentary). Kcí $\mu \varepsilon v \alpha$ (something already «set» and «established») cannot refer to the primordial mixture of chaotic matter, and $\mu \varepsilon \tau \alpha \theta \varepsilon \dot{\varepsilon} \mu \varepsilon v \sigma$ vel sim. is unparalleled as a cosmogonical operation of $\mathrm{god} / \mathrm{mind}$. Both words are grammatical terms: $\kappa \varepsilon i ́ \mu \varepsilon v \alpha$ refers to óvó $\mu \alpha \tau \alpha$, whether mentioned in the preceding context or implied; $\mu \varepsilon \tau \alpha \tau i \theta \varepsilon \sigma \theta \alpha \mathrm{l}$ ơvo $\mu \alpha$ is a well-attested phrase: $\tau$ ov̌vo $\mu \alpha$ Arist. fr. 519; ỏvó $\mu \alpha \tau \alpha$, to change the use of words in Epicur., Usener, Gigante, Schmid 1977: 435;

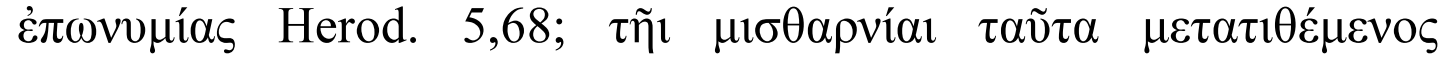

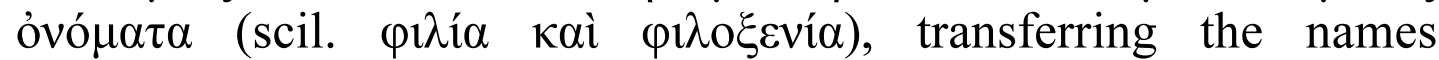
«friendship and hospitality» to the wage-earning, Demosth. 18,284. In the Demosthenes passage the phrase refers to the use of words not in their proper, commonly accepted sense.

Of special interest for us is the use of $\mu \varepsilon \tau \alpha \tau \imath \theta \varepsilon$ c $v \alpha$ obvo $\mu \alpha$ in Plato's Cratylus in close proximity with the mention of Prodicus' 50 -drachmas lecture on the «correctness of names» (384b). In 384d 
Hermogenes, who advocates the conventional character of all names and denies that there is "any other correctness» except «convention

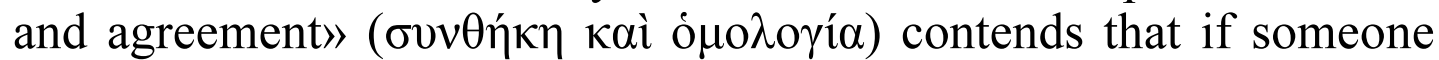
sets a name for a thing ( $\alpha^{2} \theta \tilde{\eta} \tau \alpha \mathrm{l}$ óvo $\mu \alpha$ ), it will be correct, and if he re-sets $(\mu \varepsilon \tau \alpha \theta \tilde{\eta} \tau \alpha 1)$ another name, it will be equally correct, as is the case when we rename $(\mu \varepsilon \tau \alpha \tau \imath \theta \varepsilon \dot{\varepsilon} \mu \varepsilon \theta \alpha)$ our servants.

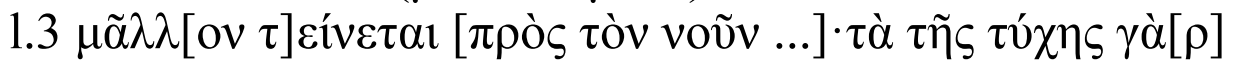

LSJ s.v. $\tau$ cív $\omega$ A, I, 4 'aim at, direct upon a point', explained as a metaphor from toxotic art: originally 'to stretch, i. e. to point a bow

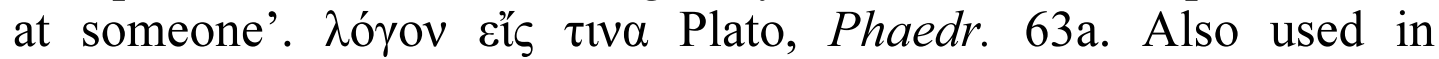
commentaries and scholia (not in LSJ): Eustath. Comm. in Il. v.4,

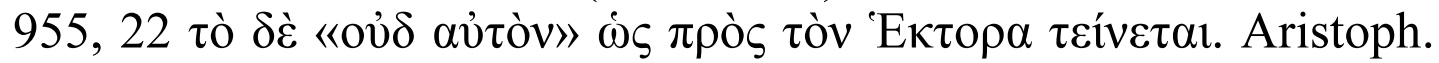

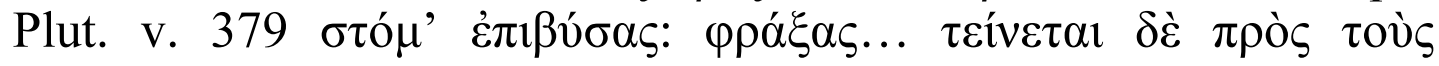

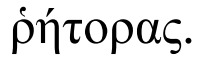

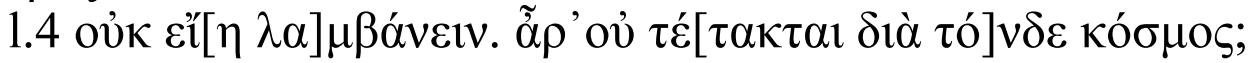

We agree with KPT, 153 that Ein is an impersonal optative potential without $\alpha v$ as in col. XXV, 8, but the verb has nothing to

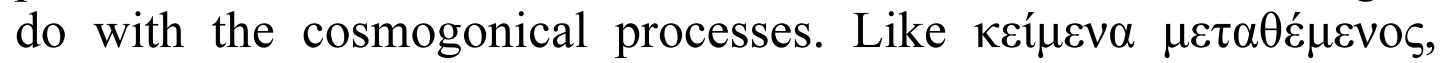
$\tau \varepsilon i v \varepsilon \tau \alpha 1$ it is a grammatical term, it means 'to take in certain sense',

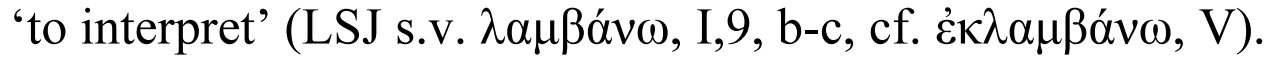

The perfective verb $\tau \dot{\varepsilon} \tau \alpha \kappa \tau \alpha l$ (with allusion to cosmogony) goes

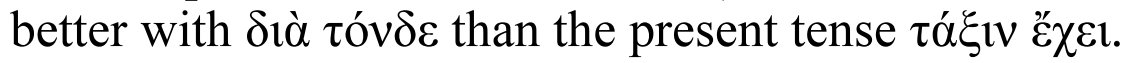

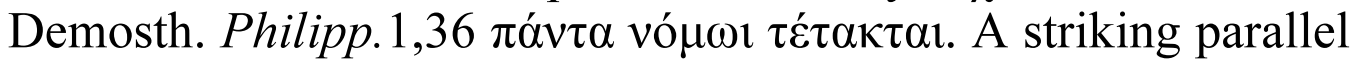
from Aristotle's Metaphysics $\Lambda$ chapter 10 in a heraclitising context:

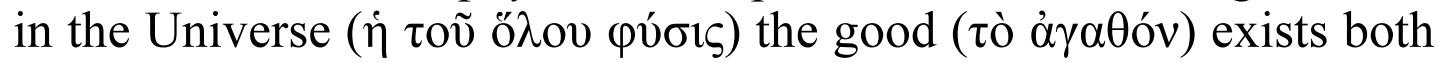
as something separate (like a general of the army) and as something immanent (the order, $\tau \alpha \dot{\xi} \xi \varsigma \zeta$ in the army): 1075a $16 \pi \alpha \dot{\alpha} \tau \tau \alpha \delta \dot{\varepsilon} \sigma v v \tau \dot{\varepsilon}-$

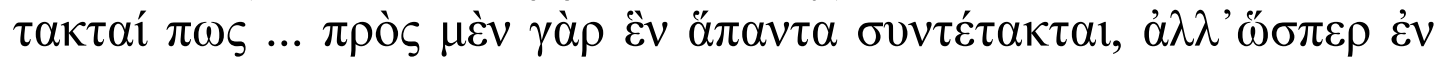
oíkíal $\tau$ oĩ خे $\tau \grave{\alpha} \pi \lambda \varepsilon \tilde{\sigma} \sigma \tau \alpha \tau \dot{\varepsilon} \tau \alpha \kappa \tau \alpha l \kappa \tau \lambda$. It is emphasised that the order in the army exists because of the general, but not vice versa: a15 oủ yò $\rho$

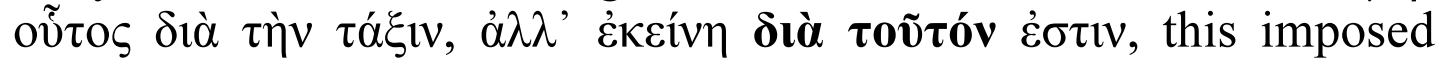
order, as in col. IV under discussion, does not allow to act by chance

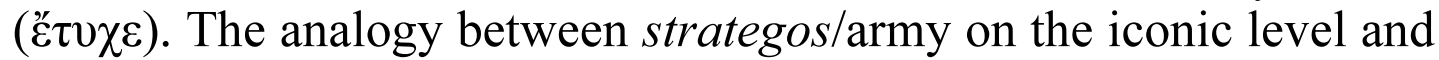
god/Universe on the referential level looks Heraclitean: in Heraclitus Polemos (= Zeus) is the supreme commander in the cosmic war of elements, and god is conceived as voũ $(=\Gamma \nu \omega ́ \mu \eta$ in the Ionian dialect of Heraclitus).

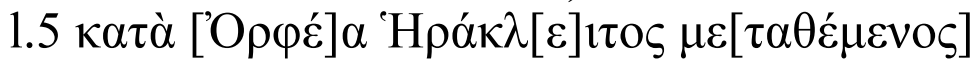

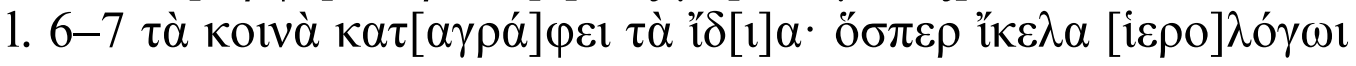
$\lambda \varepsilon ́ \gamma \omega v \cdot[$ vóos?

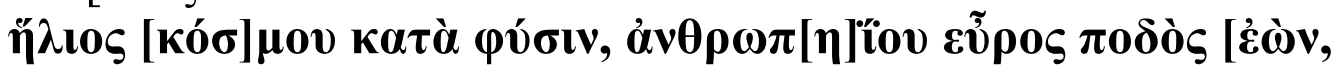




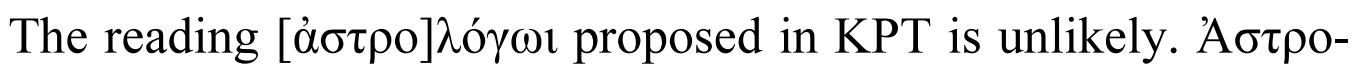
$\lambda$ óyo $s$ in early usage could only mean 'astronomer', but astronomers do not speak about Erinyes, mythical language is appropriate for a hierologos. According to the Derveni author, Heraclitus, like Orpheus, uses mythical names to describe cosmic processes and cosmic order, not in the sense intended by hoi polloi: in Heraclitus Erinyes are not terrible mythical creatures, but physical forces that sustain the cosmic order. These are «peculiar» words ( $(\delta i \alpha$ óvó $\mu \alpha \tau \alpha$ ) the meaning of which is accessible only to 'those who understand

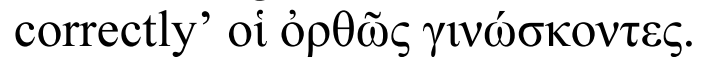

What we expect at the end of line 6 is either a verb meaning 'to rule', 'set in order' on which the genitive kó $\sigma \mu$ ov depends (e.g.

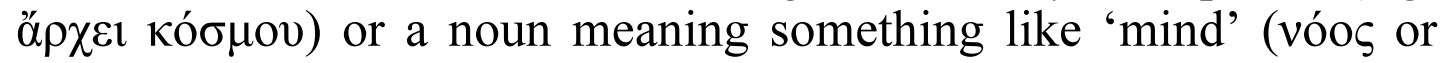

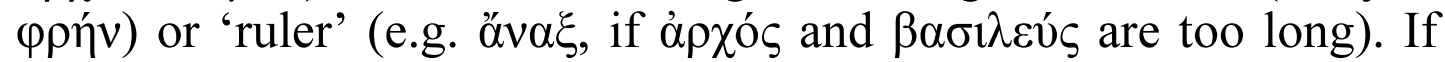
these supplements are too long, we should postulate a lacuna between line 6 and 7 , since $\eta \bar{\lambda}$ ios cannot stand on its own without a

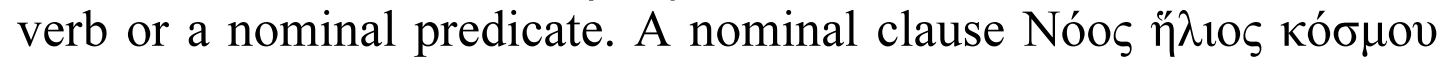
with asyndeton and hyperbaton instead of the ordinary $\dddot{\eta} \lambda$ ió $\varsigma \dot{\varepsilon} \sigma \tau 1 v$

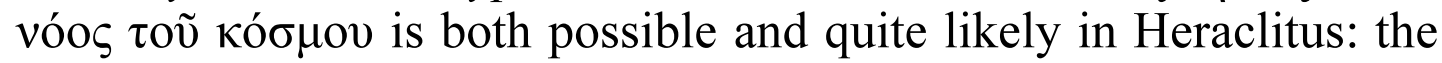
omission of articles and nominal clauses with asyndeton are well

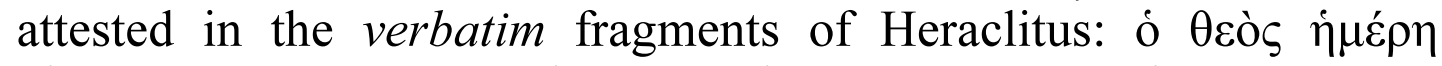

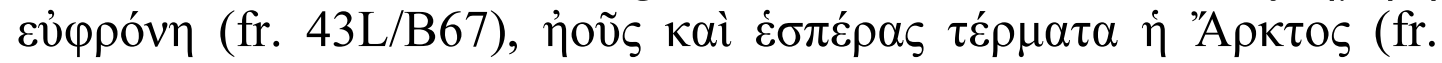

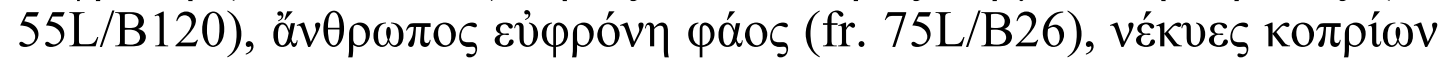

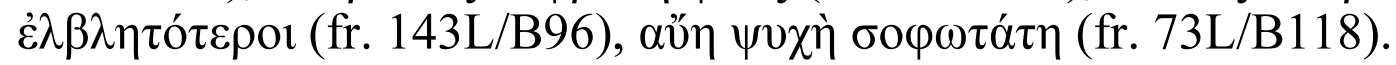

Cleanthes' identification of the Sun with the «heart of the cosmos», the seat of the cosmic mind and the «ruling principle» ( $\tau$ ò $\dot{\eta} \gamma \varepsilon \mu$ ovikóv) of the $\operatorname{cosmos}^{106}$, has ancient roots and can be traced back to Heraclitus. It is attested both in a verbatim quotation from Heraclitus and by a remarkable convergence of several independent testimonia in the Heraclitean tradition. In Heraclitus fr. 57L/B 100

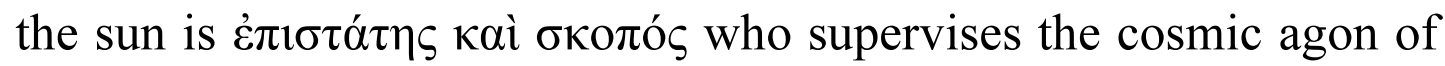
the seasons (Homeric бколós is Heraclitus' authentic word, $\dot{\varepsilon} \pi 1 \sigma \tau \alpha \dot{\tau} \tau \zeta \varsigma$ seems to be Plutarch's gloss of it) ${ }^{107}$. De diaeta I,10 غ́v

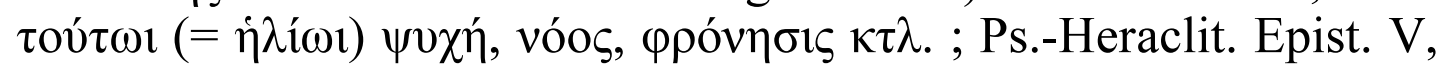

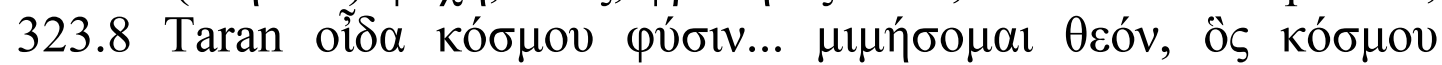

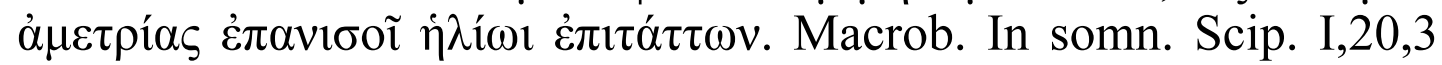
(«sol dux, princeps et moderator reliquorum») hunc ducem et principem quem Heraclitus fontem caelestis lucis apellat. Plat. Crat.

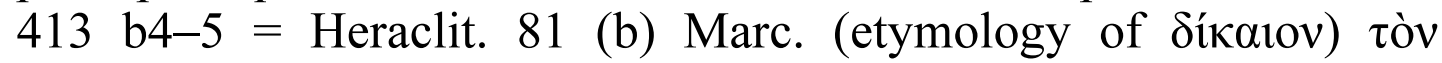

${ }_{106}^{106}$ See the list of instances in SVF, IV, 67 s.v. $\ddot{\eta} \lambda 10 \varsigma=\dot{\eta} \gamma \varepsilon \mu$ ovıкóv.

${ }^{107}$ On the text of fr. 57L/B 100 see Lebedev 1985; 2014: 374-375. 


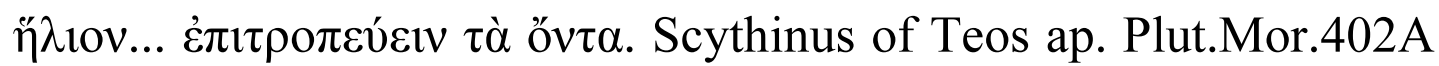
$=$ Heraclit. Probab. fr. 13 Leb.

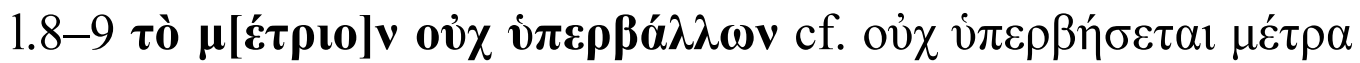
in Plutarch's quotation De exil.604A, for the phrase $i \pi . \tau . \mu$. Demo-

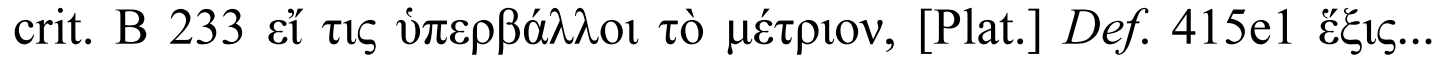

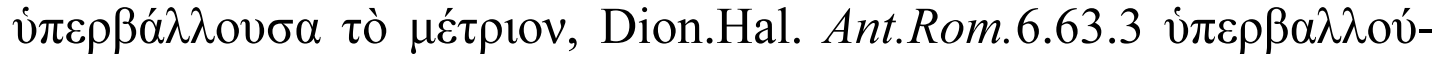

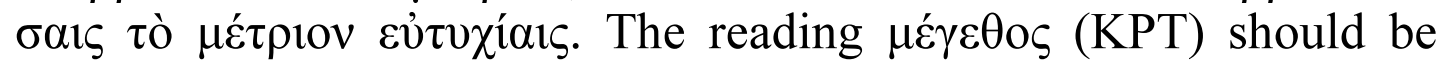
ruled out for several reasons. 1) It is an Attic and koine form, Herodotus has only $\mu \varepsilon \dot{\gamma} \alpha \theta$ os. 2) It is pleonastic and duplicates eṽoos. 3 ) It is imposed by the mistaken «quantitative» interpretation of «cosmic measures» in Heraclitus. 4) In restoring the original text of Heraclitus' fragments we adhere to the general rule that a vebatim quotation in Ionian dialect should not be «emended» on the basis of a doxographical paraphrase. But $\tau$ ò $\mu \varepsilon \dot{\varepsilon} \varepsilon \theta 0 \varsigma$ is not even a part of

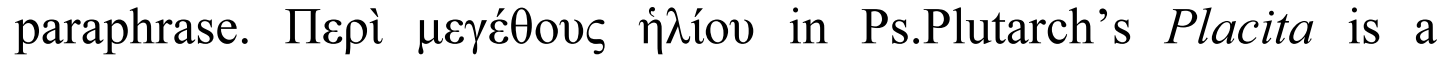
heading of a chapter in a handbook of physics of imperial times (on the origin of the doxographical tradition of «Placita philosophorum» see Lebedev 2016).

Heraclitus was an ethico-religious and political thinker, not a physical scientist like Anaxagoras or Democritus. The «size» of the heavenly bodies was the last thing in which he was interested; for him, as later for Socrates, it was a worthless $\pi \circ \lambda v \mu \alpha \theta \varepsilon \varepsilon 1 \alpha$. In his politico-theological «cosmology» he was primarily interested in the regularity of the cosmic cycles of alternating opposites (day - night, summer - winter, koros and chresmosyne of the Megas eniautos), which is directly llinked with his theory of the natural law («cosmic justice»). Tò $\mu \varepsilon \dot{\tau} \tau \rho ı v$ in ethico-political discourse is often associated

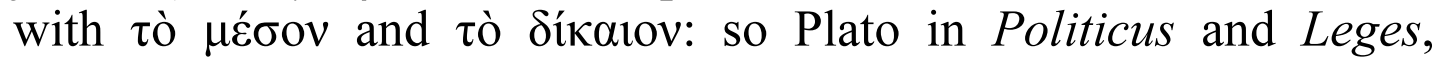
Aristotle in EN, already Democritus anticipates Aristotle by

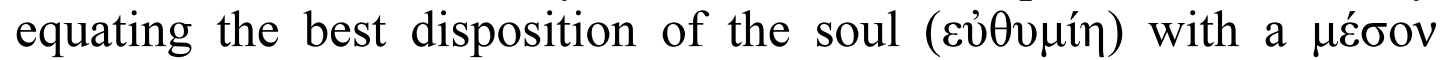
between $\dot{v} \pi \varepsilon \rho \beta 0 \lambda \eta \dot{~ a n d ~} \varepsilon \lambda \lambda \varepsilon 1 \psi 1 \varsigma$ (B 191). The sun-god in the polis of Zeus sustains the perfect balance of opposite forces in the cosmos by alternating the periods of heat (summer) and cold (winter), cf. Alcmaeon's concept of isonomia ${ }^{108}$.

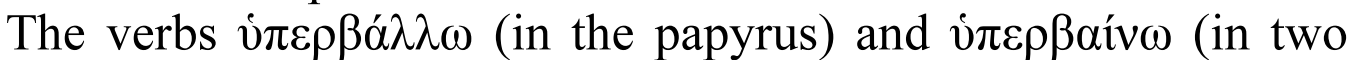
Plutarch's quotations from memory) are roughly synonymous, but the former is more often used in the sense of «exceeding» a term (like the dates of $\tau \rho o \pi \alpha i$ ) or a period of time, cf. LSJ A II, 2. In a context very similar with Heraclitus' Oxyrrhynchus fragment about

${ }^{108}$ In Lebedev $2017_{3}$ we have argued that Heraclitus may have used the term ioovouía in his cosmological historiosophy. 
the phases of the moon ( $\left.\dot{\varepsilon} v \dot{\eta} \mu \varepsilon \cos _{\rho} \varsigma \varepsilon \sigma \sigma \alpha \rho \alpha \kappa \alpha i \delta \varepsilon \kappa \alpha\right)^{109}$, the Hippo-

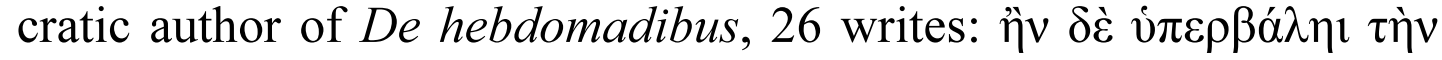

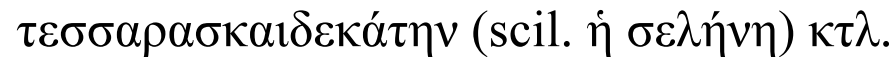

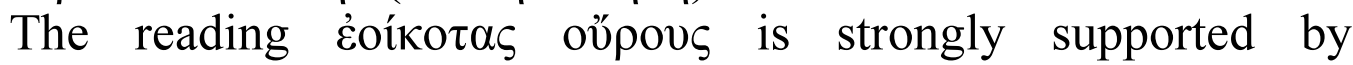

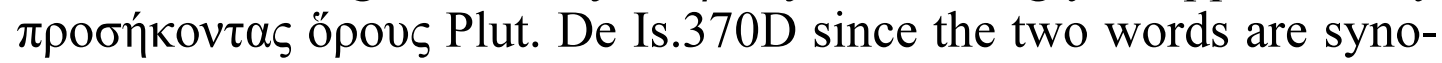

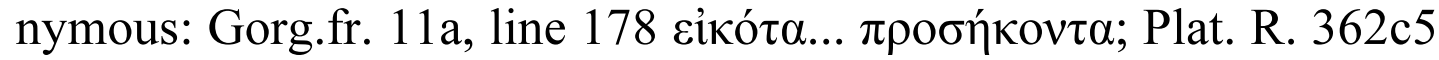

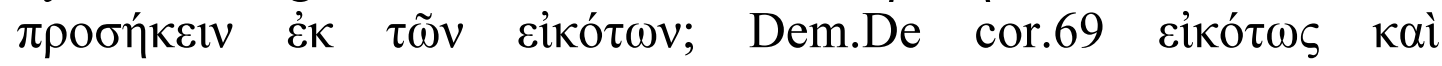
$\pi \rho о \sigma \eta \kappa o ́ v \tau \omega \varsigma$.

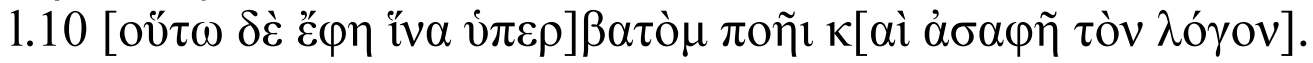

When reconstructing and interpreting a defective text one should carefully study the usage of the given author and take it into account, as well as always respect Greek grammar and morphology. Those who mistranslate $\dot{\pi} \pi \varepsilon \rho \alpha \tau$ óv in line 10 as «transgression» ${ }^{110}$ violate both of these principles at once: they neglect the evidence on

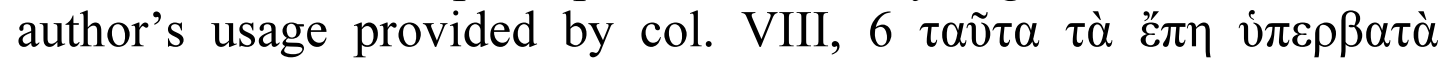

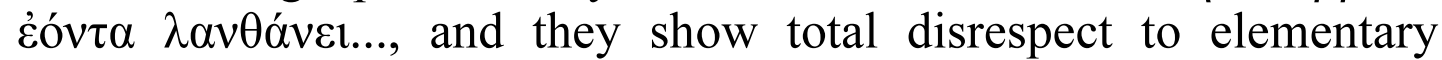
Greek morphology by translating i $\pi \varepsilon \rho \beta \alpha \tau o ́ v$ as a nomen actionis. By all standards of the Greek morphology a nomen actionis from

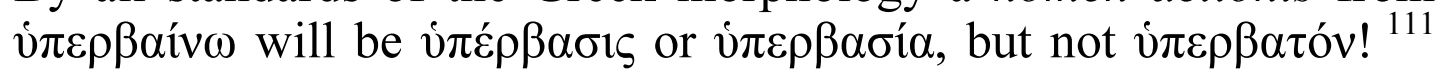
Both in col. VIII and in col. IV vi $\pi \varepsilon \rho \beta \alpha \tau o ́ v$ has nothing to do with the physical processes and «cosmic measures», but is a grammatical and rhetorical term for the transposition of words. ${ }^{112}$ An attention to

${ }_{109}$ POxy. 3710, col. ii, 43-47 = Heraclit, fr. 60 Lebedev.

${ }_{110}^{110}$ Laks, Most 1997: 11; Betegh 2004: 11; Janko 2001: 19 («surpassing»).

${ }^{111}$ The original source of this mistranslation seems to be Mouraviev 1985: 131. We pointed to this already in Lebedev $1989_{1}: 39$, note 1 . For dozens and dozens of similar wild and incomprehensible mistakes in his «edition» of Heraclitus see our review in VDI 2013, № 4, 174-186 with English translation available at https://www.academia.edu/7797997/Review of Mouraviev's_edition_of_Heraclitus._English_version. Mr. Mouraviev is an advocate of «alternative philology» according to which we should search for the meaning of Heraclitus' text not in his words and philosophical ideas, but in some «hidden patterns», i. e. symmetrical configurations of separate letters and alleged cryptic anagrams. After grasping these «hidden patterns» we are advised to discern also a second set of faces in the clouds, namely to arrange the texts of the fragments in the form of alleged carmina figurata since according to Mr. Mouraviev Heraclitus wrote syllabo-tonic poetry like Byron and Poushkin. There is no wonder that Mr. Mouraviev who ignores elementary Greek grammar (e.g. he prints in his edition $\pi \alpha ́ v \tau \alpha$

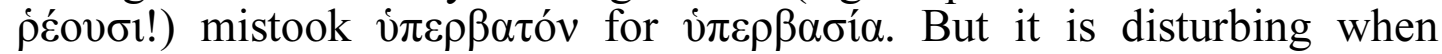
serious scholars and professional Hellenists repeat this mistake of an incompetent amateur: it shows how contagious pseudo-science can be.

${ }^{112}$ Betegh 2004. On hyperbaton see Kühner, Gerth 1982, II/2: 600, § 607; Devine, Stephens 2000. 
hyperbaton was a characteristic feature in Protagoras' interpretation of poetry (Plat.Prot.343e), and Protagoras was regarded as a teacher of Prodicus. The mention of the figure hyperbaton in a commentary on Heraclitus' style is to be expected since Heraclitus from early

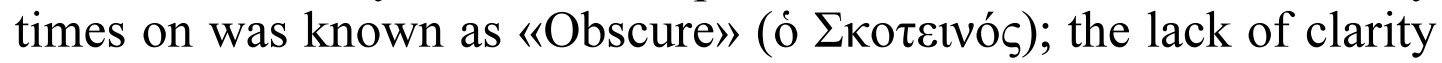

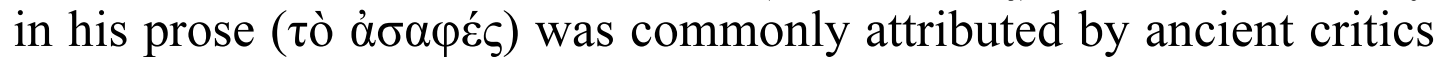
to the use of words in a non-proper sense (lexical means), and asyndeton (or lysis), hyperbaton and ambiguity (amphibolia) in the syntax and word order. The authentic fragments of Heraclitus contain at least 9 instances of the syntactical ambiguity (amphibolia) noticed already by Aristotle (Lebedev 2014: 48-49). Hyperbaton and the syntactical ambiguity are related phenomena: whereas Demetrius attributes the obscurity of Heraclitus to lysis (asyndeton), Theon Alexandrinus explains it by the heavy abuse of syntactical ambiguity (amphibolia) resulting from the difficulty of division of text (diairesis, the same as diastixis in Aristotle's passage). The discussion of hyperbaton and the ambiguity of aidoĩov in PDerv. col. VIII + XIII that can be construed either with the preceding $\varepsilon \bar{\varepsilon} \lambda \alpha \beta \varepsilon v$ or with the subsequent $\kappa \alpha \tau \varepsilon \dot{\pi} \mathrm{iv \varepsilon v}$ looks similar to Aristotle's discussion of the ambiguous position of $\dot{\alpha} \varepsilon$ í in Heraclitus fr. 2L/B 1 . In Heraclitus' fragment about the Sun in PDerv col. IV there is a clear instance of at least one hyperbaton in line 7: $\alpha v \theta \rho \omega \pi[\eta]$ iov

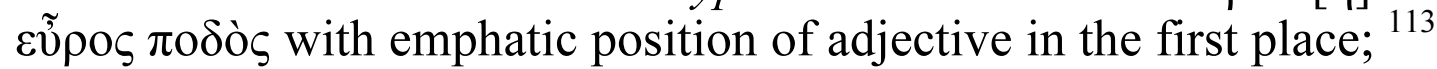
the «natural» word order is restored in the quotation of these three

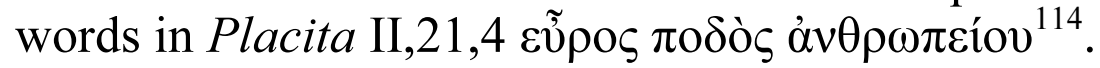

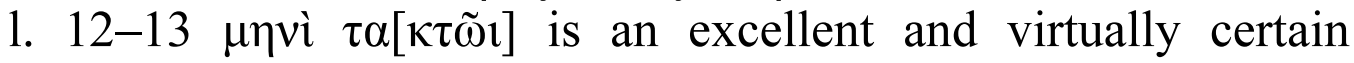
supplement of KPT. The «fixed month» is a month of the solstice, June for the Summer solstice and December for the Winter solstice. Solstices ( $\tau \rho \circ \pi \alpha i ̀ ~ \dot{\eta} \lambda$ íov) were of greatest importance in Heraclitus

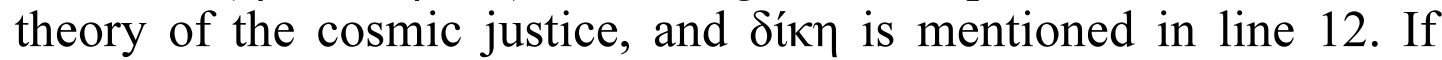
vं $\varepsilon \rho \beta \alpha \tau$ óv is a rhetorical term of the commentator, lines 11-13 are not by Heraclitus, but a part of the commentary. In any case

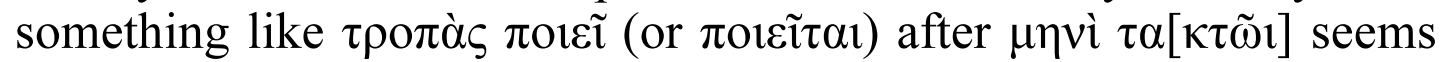
very likely: a TLG proximity search for this phrase yields 60 instances $(\tau \rho . \pi$ olei or $\pi 01 \varepsilon i \tau \alpha l)$ in astronomical texts, it was a fixed

${ }^{113}$ Hyperbaton type Y1 according to Devine, Stephens 2000: 31, $33 \mathrm{ff}$.; Denniston 1952: 47 «emphatic word placed early in violation of natural word order».

${ }^{114}$ (Stob. I,25). Heracl. fr. 56 L (b) = B 3 DK. We do not quote «Aëtius», one of the many distortions of pagan names in Theodoretus. For a detailed criticism of Diels' mistaken attribution and of the Neo-Dielsian doxographical theory of Mansfeld and Runia see Lebedev 2016. 
phrase that was used with a dativus temporis specifying the month of the solstice. The phrase occurs in the doxography of Anaximander (A 27), Anaximenes (A 15), Anaxagoras (A 42); it is hard to imagine something very different from this in the original Preplatonic texts. Nevertheless it looks as an explanation in plain «common words» of Heraclitus' mythopoetic «peculiar» expressions.

Janko's $\alpha \mu \eta ́ v ı \tau \alpha$ (accepted by Cotwick) is unfortunate: it is an archaic and poetic word (Archilochus, thrice in Aeschylus) derived from the Homeric $\mu \tilde{\eta} v i \varsigma$, unknown in prose (with a single exception Herod. 9.94) for more than 500 years until it resurges in Plutarch (10 instances), the lover of the antiquarian lore. The probability of its occurrence in the 5th century sophistic prose is close to zero. And

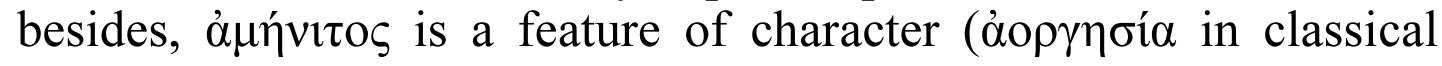
philosophical prose) possessed by the god and the wise. A sing.n. form $\tau$ ò $\alpha \mu \eta ́ v i \tau o v$ is conceivable and is attested (once in Plutarch), but the pl.n. * $\dot{\alpha} \mu \eta \dot{v i \tau \alpha}$ is hard to imagine and unattested, just as $\tau$ ò

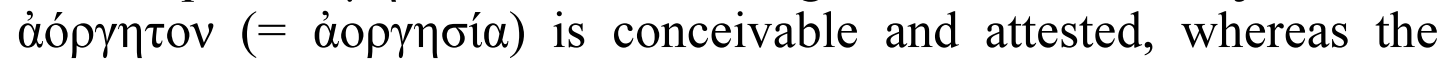
plural áó $\gamma \gamma \eta \tau \alpha$ is not found. Therefore Janko's reading should be ruled out with certainty, there is no alternative to $\mu \eta v i$ i $\tau \alpha \kappa \tau \tilde{\omega} 1$ of the KPT text.

\section{(5) A neglected reflex of Prodicus' benefaction theory and PDerv col. IV \& XXIV in Xenophon's Memorabilia.}

The fourth chapter of the book 4 of Memorabilia recounts the conversation of Socrates with Euthydemus on the divine providence and various benefactions to humanity that Xenophon happened to attend ( $\pi \alpha \rho \varepsilon \gamma \varepsilon v o ́ \mu \eta v)$. The purpose of Xenophon in this chapter is to prove that, far from being an asebes and disrespectful of $\tau \grave{\alpha} v o \mu \imath \zeta o ́-$ $\mu \varepsilon v \alpha \tau \tilde{\eta} \varsigma \pi$ ó $\lambda \varepsilon \omega \varsigma$, Socrates made all those with whom he conversed more «sound-minded» ( $\sigma \omega \varphi \rho \circ v \varepsilon \varepsilon \sigma \tau \varepsilon \rho o \imath)$ in their attitude to the

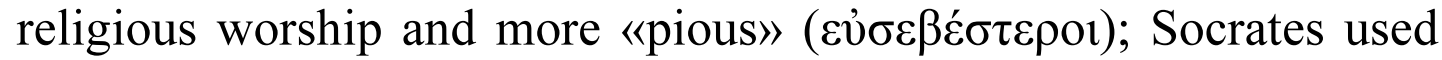
to remind them that when someone asked Apollo in Delphi how one can please the gods, the oracle replied: by observing the custom of the polis (vó $\mu \omega \imath \pi$ ó $\lambda \varepsilon \omega \varsigma)$. All necessary and «useful» things ( $\pi \alpha ́ v \tau \alpha$ $\tau \grave{\alpha} \chi \rho \eta ́ \sigma 1 \mu \alpha$ ) for the human life have been provided by the $\pi \rho \operatorname{vov} \alpha$, $\dot{\varepsilon} \pi \mu \mu \varepsilon \dot{\lambda} \varepsilon \varepsilon \alpha$ and $\varphi \imath \lambda \alpha v \theta \rho \omega \pi i \alpha$ of the gods. The first example of $\tau \grave{\alpha}$ $\chi \rho \eta ́ \sigma \mu \alpha$ are the day-light for work and night-darkness for rest. The sun is both the source of light and a natural clock that makes clear

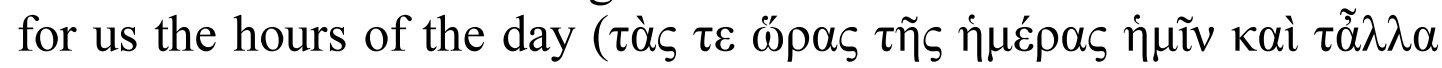

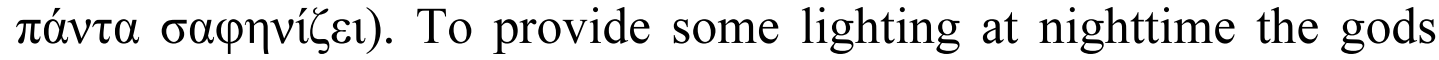
created also the stars of the night that «show us the hours of the 


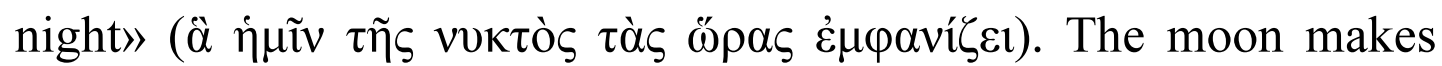
clear ( $\sigma \alpha \varphi \eta v i \zeta \varepsilon \imath)$ to us not only the "parts», i. e. hours of night, but also the parts of the month (

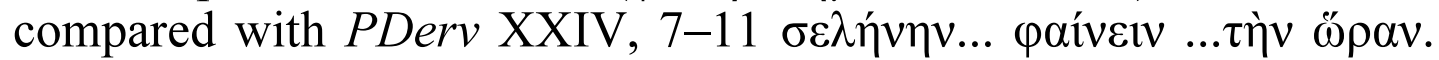
Exactly as in this column of PDerv the time-reckoning revealed by the moon serves the needs of agriculture and the production of food «from earth»: the gods provided «appropriate hours», ळ̋as $\alpha \rho \mu$ o $о$ ov $\zeta \alpha \zeta$, i. e. the seasons, for the agricultural है $\rho \gamma \alpha$ of men (4.4.5), and by adjusting the $\tilde{\omega} \rho \alpha$ to the agricultural year cycle they provided a water supply (rains) necessary for the cultivation of plants (4.4.6). The greatest gift of the gods is fire which helps humans against cold and darkness, and «helps in work towards any skill and everything that humans contrive for the sake of utility»

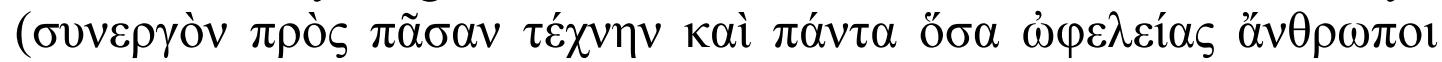
$\kappa \alpha \tau \alpha \sigma \kappa \varepsilon v \alpha \dot{\zeta}(0 v \sigma 1)$; «without fire men cannot contrive anything worth of mention out of things that are useful for the human life», ov̉ $\delta \dot{\varepsilon} v$

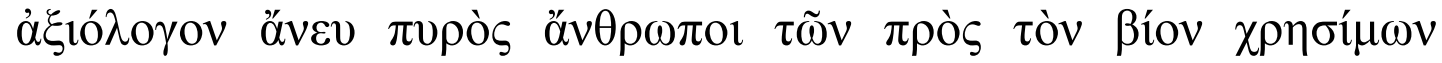
$\kappa \alpha \tau \alpha \sigma \kappa \varepsilon v \alpha ́ \zeta o v \sigma 1$ (4.4.7). This looks like a verbatim quotation from Prodicus. The following section (4.4.8) provides a remarkable parallel to PDerv. col. IV: it refers to to the winter and summer solstices $(\tau \rho \circ \pi \alpha i)$ that save us both from being frozen and being burnt to death: "Think again how the sun, when past the winter

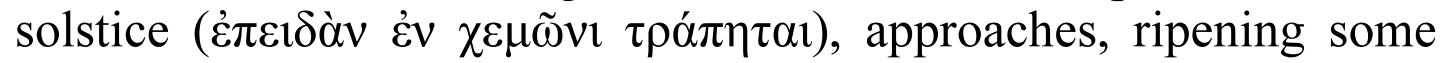
things and withering others, whose time is over; and having accomplished this, approaches no nearer, but turns away, careful not to harm us by excess of heat ( $\varphi v \lambda \alpha \tau \tau o ́ \mu \varepsilon v o v \mu \eta \dot{\eta} \tau \dot{\eta} \mu \tilde{\alpha} \varsigma \mu \tilde{\alpha} \lambda \lambda \mathrm{ov} \tau \mathrm{ov}$

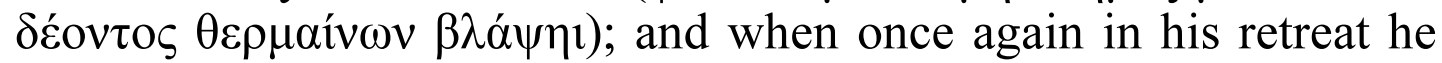
reaches the point where it is clear to ourselves, that if he goes further away, we shall be frozen with the cold, back he turns once more ( $\pi \alpha \dot{\lambda} \imath \iota \alpha \tilde{v} \tau \rho \varepsilon \dot{\pi} \varepsilon \varepsilon \sigma \theta \alpha \imath$ ) and draws near and revolves in that region on the heavens where he can best serve us» (tr. E.C.Marchant).

Xenophon was an admirer of both Socrates and Prodicus. He quotes in Memorabilia book 2 his version of Prodicus' Heracles story $^{115}$. The connection of Mem. 4.4 with Prodicus' Horai and the

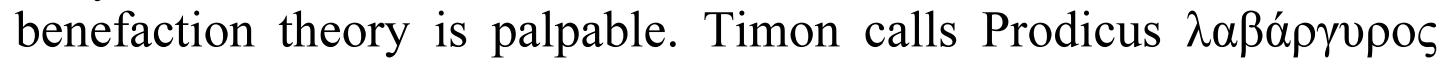

${ }^{115}$ Mem.2.21-34 = Prodic. 83 M. Speculations about «Stoic interpolations» in Xenohon are persuasively refuted by Parker (1992) with an important list of 5th century parallels (pp. 87-88). Parker leaves undecided the question about the original source of the «transformation in thought» (p. 94), i. e. the invention of the argument from design. For us this is not a «mystery» anymore: Heraclitus is certainly one the main sources with Pythagoras and Pythagoreans as plausible precursors. 


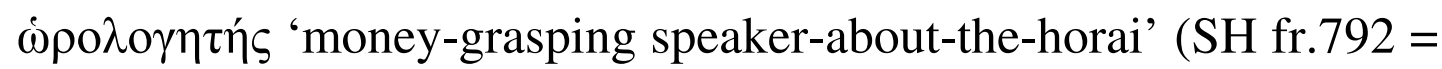
Prod. T9 M.), an allusion both to his opus magum and his "charging by hour." But there is one significant discrepancy, even a

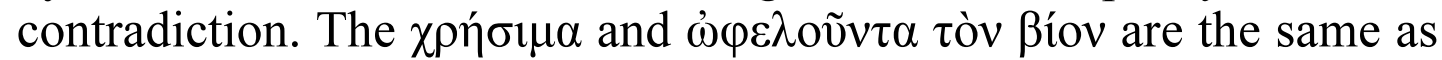
in Prodicus, but they have been reinterpreted as gifts of the gods, as a result of which Prodicus' «atheistic» theory of religion has been transformed into its creationist opposite, the traditional popular belief in divine $\pi \rho \tilde{\omega} \tau o$ ev $\rho \varepsilon \tau \alpha i$. To resolve this contradiction we have to choose one of the following scenarios.

1) The conversation of Socrates and Euthydemus in Mem. 4.4 has been invented by Xenophon. He took Prodicus' benefaction theory, made a «pious» version of it and put it into Socrates mouth as a proof of his religiosity with apologetic purpose.

2) The conversation is real, at least in substance. In this case the "pious» version of the benefaction theory was held by historical Socrates. And if so, it might derive from Socrates' dispute with Prodicus and might be his (and not Xenophon's) dialectical peritrope of Prodicus' Horai inspired by Heraclitus.

The natural theology of Socrates' speech in Mem. 4.4 has much in common with Heraclitus: Heraclitus' fragment on the $\tau \rho \circ \pi \alpha i$ of the sun quoted in PDerv.col. IV was in its original context in Heraclitus' work exactly such teleological $\tau \varepsilon \kappa \mu \eta \dot{p t o v ~ o f ~ t h e ~ d i v i n e ~}$ providence $(\Gamma \nu \omega ́ \mu \eta)$ and a refutation of the Milesian mechanistic

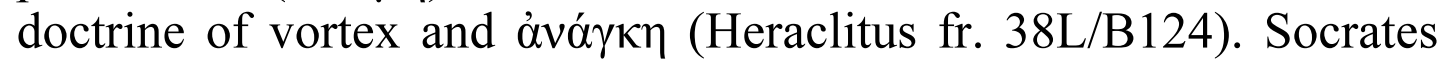
the reader of Heraclitus (D.L. 2.22) may be something more than an anecdote: our reconstruction of the «technological» section of

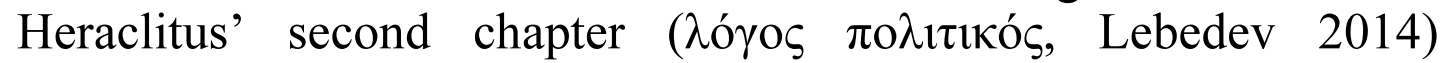
indicates that the use of $\tau \dot{\varepsilon} \chi v \alpha l$ analogies in the Socratic dialogues may have been inspired by Heraclitus. In other words, the historical Socrates may have relied on Heraclitus in his real debates with Prodicus and other sophists.

We leave the matter undecided. The vexed question of Xenophon's credibility as a source on Socrates' philosophy should not concern us at present. In any case Xenophon's passage brings an additional confirmation to our ascription of PDerv to Prodicus and should be added to the testimonia in the section (3) above.

(6) The title and date of the Derveni Treatise. Its relation to the Psephisma of Diopeithes and the trial of Anaxagoras.

Title

Let us start with a list of candidates from extant sources. 
1) Themistius quotes Prodicus allegorical interpretation of

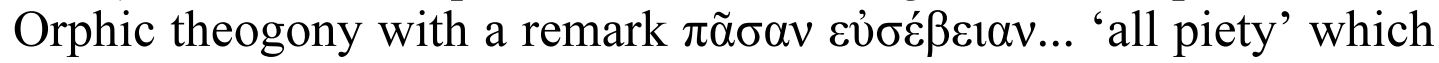

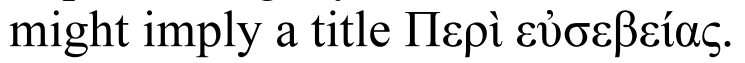

2) The combination of two possible quotations of Prodicus' etymologies of divine names in Plato, Cratylus, 409a9 $\pi \alpha \lambda \alpha$ ió $\tau \varepsilon \rho o v$

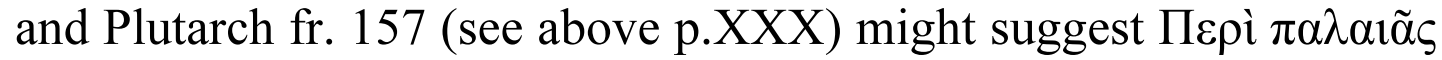

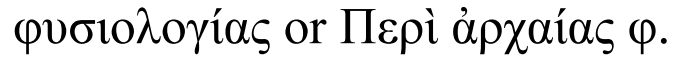

3) Given that the author of DervT is Prodicus of Ceos, a disciple of Protagoras, and that by its literary genre the DervT is related with the Sophistic Kulturgeschichte, two titles of Protagoras' works seem

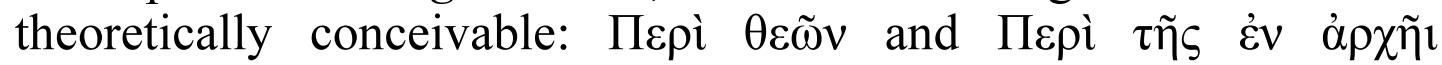

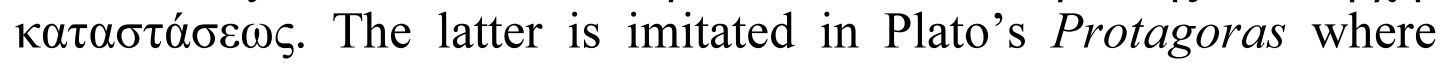
Prodicus is also mentioned.

4) Plato in Cratylus discusses etymologies of the divine names similar to those found in PDerv after emphatic (in the very beginning) reference to Prodicus' «fifty drachmas» lecture «On the

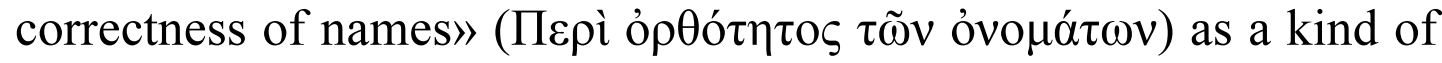
a classic of the genre.

5) In Aristophanes' parody of Prodicus' allegorical interpretation of the Orphic theogony (Av. 709) the «greatest» gifts of birds to human race is time-reckoning and indication of seasons ( $\Omega \rho \alpha 1)$, cf. PDerv. col. XXIV,10-11.

Of all the candidates the last one seems to be the most promising and better documented. ${ }^{2} \Omega \rho \alpha$ or «Seasons» was considered already by Prodicus' contemporaries as his masterpiece. According to the scholiast, it contained the famous protreptic to virtue, the story of Heracles. In the earlier scholarship the word Horai was understood in a narrow sense as a reference to Heracles' maturity (Diels-Kranz, Bd. II: 312, n. 20). According to Nestle (1936) it was much broader in scope and consisted of three parts: (1) the praise of agriculture, (2) the origin of religion and (3) the story about Heracles. According to the ingenious reconstruction of Mayhew Horai consisted of two parts: Part 1 on the early «seasons» of human race and Part 2 one the seasons of human life (including the story of Heracles) ${ }^{116}$. The first part included: 1) the miserable life of the wretched primitive people alluded to in Aristophanes' Birds 685-87, 2) the origin of religion stage one: humans deify the beneficial natural phenomena, 3) the origin of religion stage two: humans deify the inventors of tekhnai with special emphasis on agriculture and viticulture. In both stages,

\footnotetext{
${ }^{116}$ Mayhew 2011: XXII. On the early history of the philosophical topos «the seasons of life» see also Lebedev 2017.
} 
according to Mayhew, «etymologically appropriate names are given» to the objects of deification (loc.cit.). Our reconstruction and reading of the Derveni treatise perfectly fits into Mayhew's Part 1. However, one difficulty remains. Prodicus was famous for his exquisite style, and Heracles story (allegedly a part of Horai) was praised by Xenophon as a literary masterpiece. The style of the Derveni treatise is anything but Kunstprosa (with the exception of col. V, XX and XXII on which see Lebedev 2019). To resolve this difficulty we have to admit that the text of PDerv is a sophistic lecture based on Horai. This hypothesis explains the sporadic change of style from a simple to an exquisite: it was recommended by Prodicus as a didactic device to keep his listeners awake ${ }^{117}$. Col. $\mathrm{XX}$ looks like an «insertion» ( $\pi \alpha \rho \varepsilon \mu \beta \mathrm{o} \lambda \eta \dot{)}$ from the 50-drachma lecture $^{118}$. Pace Nestle and Mayhew, we have some doubts about the possibility to integrate both the Heracles' choice and the treatise on the origin of religion and civilization into one and the same work. The former has nothing to do with agriculture and Kulturgeschichte, the latter has nothing to do with practical ethics. Stylistic differences alone make this integration unlikely ${ }^{119}$. The choice of Heracles is quoted by many authors, but it is cited under somewhat surprising title «Seasons» only once in a scholium to Nubes 361. It fits much better a historical work in which agriculture was an important

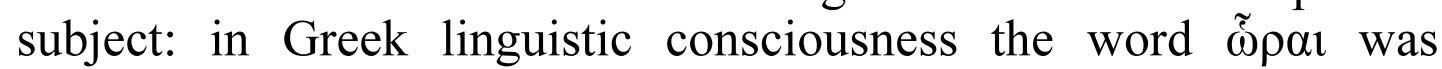

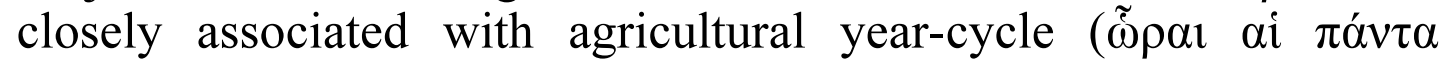
$\varphi \varepsilon ́(\rho) \sigma 1)$. The scholiast may have conflated two most famous and influential works of Prodicus into one. Diels's suggested that $\tilde{\Omega} \rho \alpha 1$

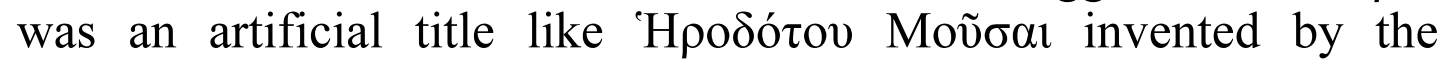
Alexandrians (Diels-Kranz, Bd. II: 312, n. 20): just as the title «Muses» of Herodotus refers to 9 books, just as the $\Phi 1 \lambda \mathrm{o} \lambda \alpha \operatorname{cov}$ Bók $\chi \alpha 1$ (a sculpture group of three bacchants) refers to the three

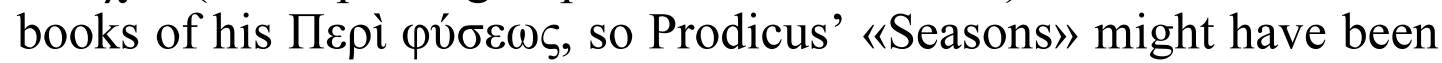
attached by librarians to a collection of different speeches and works

${ }_{118}^{117}$ Arist. Rhet. $1415 \mathrm{~b} 12=$ Prod. $41 \mathrm{M}$.

118 But this is uncertain. The style and the sarcastic tone of col. XX resembles that of col. V which displays affinity with Heraclitus.

${ }_{119}$ In the controversy on the authenticity of Xenophon's exposition of Heracles' choice we side with Sansone 2004 and Mayhew 2011: 204

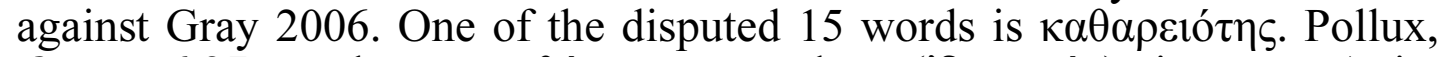

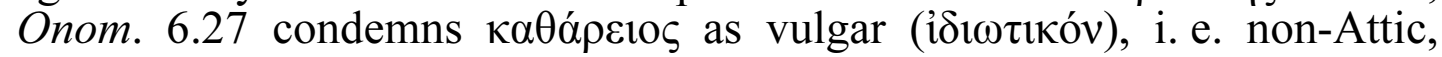
despite one instance of $\kappa \alpha \theta \alpha \rho \varepsilon i \omega s$ in Xen. Cyn. 1, 3, 8. Plato has only

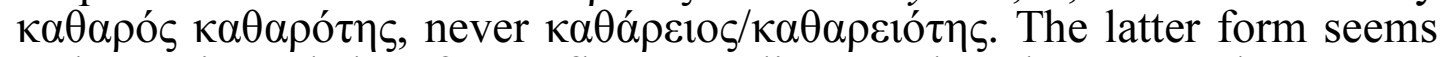
to be Ionic and therefore reflects Prodicus' rather than Xenophon's own regular usage. 
in 4 books. But the Alexandrian origin is unlikely since the title ' $\Omega \rho \alpha$ is alluded to already in Aritstophanes (both in Birds and the neglected fragment from the Seasons), in Xenophon Mem.4.4 (see section 5 above) and in Timon's sobriquet of Prodicus $\omega \rho$ po (see above after note 115). In Themistius $\tilde{\omega} \rho \alpha 1$ are also associated with Prodicus' theory of religion, but not with Heracles' choice. Heracles in the moral parable about virtue is a conventional literary fiction; Heracles in Prodicus' history of religion would have been presented as a real deified king or benefactor of the past in the second stage.

The Date. The relation of DervT to the psephisma of Diopeithes and to the trial and death of Anaxagoras.

The date. The firm terminus ante quem is established by the production year of Aristophanes' Birds: 414 B.C. However, in view of the close relation of the cosmogony of Birds with the cosmology of Clouds (dinos-motif), and especially in view of the allusion to teletai in both comedies and plausible quotations from DervT in Nub. 382, 828 the terminus ante quem should be pushed up to 420 17 (the extant version of Clouds) or even 423 (the first version), since the image of Nephelai cannot be separated from the «air» and the vortex cosmogony. A plausible terminus post quem is the Psephisma of Diopeithes $433 / 432$ B.C ${ }^{120}$ or rather the trial of Anaxagoras (c. 430) or even his death (428) since the DervT looks like a «response» to these events. Therefore a date soon after the trial or death of Anaxagoras, i. e. early twenties, looks especially plausible. How do we know that the Derveni Treatise was written after and in response to the psephisma of Diopeithes rather than before it? Why not to suppose that it was one of the targets of Diopeithes? The first possibility explains better the extravagant figure of Orpheus the Anaxagorean. Before the psephisma any Anaxagorean and the sophists could without fear express their views on nature and the cosmos and $\tau \grave{\alpha} \mu \varepsilon \tau \alpha \dot{\rho} \rho \sigma 1 \alpha$. Now one had to be cautious in order to avoid the charge of impiety. Orpheus the Anaxagorean was at the same time a parody (or a polemical peritrope, see section 7 below), a protective device against the charge of impiety and an apology of Anaxagoras. The psephisma of Diopeithes introduced the prosecution by eisangelia (i. e. as

${ }^{120}$ On the trial of Pericles and psephisma of Diopeithes see Rubel, Vickers 2014: chapter 2.5-6. who argue for a date after 430. Contra Mansfeld 1980: 88 who proposes 438/7 B.C. 
offenders against the state) of those who do not recognise the traditional religion of the polis and teach astronomical theories $(\log o i)$ that deny the divinity of heavens ${ }^{121}$. The traditional views about gods and the religious institutions were commonly referred to

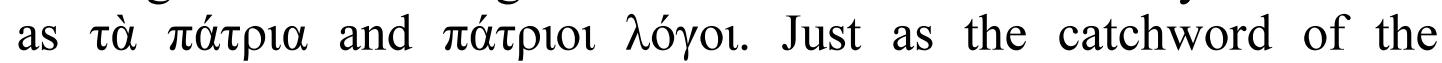
conservative political discourse was $\pi \alpha ́ \tau \rho ı \varsigma ~ \pi \circ \lambda ı \tau \varepsilon i ́ \alpha$ and $\pi \alpha ́ \tau \rho ı 1$ vó $\mu$ or, so the catchword of the lexicon of the religious conservatives

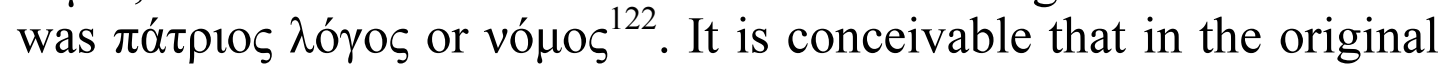
formulation of the psephisma briefly paraphrased by Plutarch

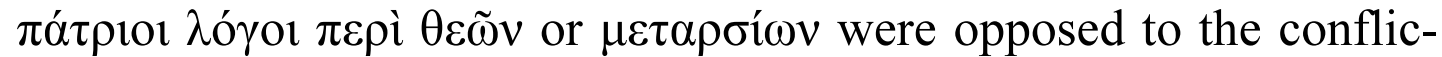
ting «new doctrines», the target being Anaxagoras and the sophists who teach new astronomy and corrupt the young. In any case the author of the DervT could not be formally accused of rejecting the "ancestral doctrines»: on the contrary he expressed «admiration» for the ancient wisdom of Orpheus, he only offered a «corrected» interpretation of his poetry. By proving that Anaxagoras' astronomy is in perfect agreement with the «ancestral wisdom» of Orpheus, the founder of Greek religion, Prodicus was also absolving Anaxagoras from the charge of asebeia. About the same time another disciple and friend of Anaxagoras, Euripides, in his Hippolytus (428 B.C.) launched an attack against «the books of Orpheus» and the puritanic Orphic life targeting the ideology of Diopeithes \& $\mathrm{C}^{\mathrm{o}}$. Euripides probably did this on the occasion of the Anaxagoras' death in Lampsakos the same year. The angry invective of the father of Athenian demos, Theseus, against the «insane» obsession of the egocentric Hippolytus with ritual purity contains a hyponoia with a counter-accusation of «impiety»: the Orphic-Pythagorean vegetarian

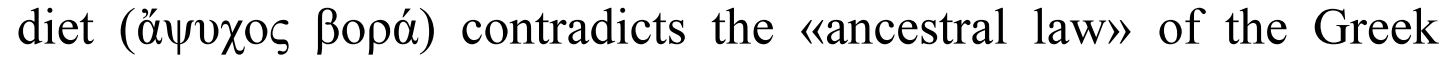
religion, that of the animal sacrifice (Hippol. 928 ff.). The restoration of the correct reading by Cristian Vassallo provides a unique new evidence that Anaxagoras was tortured ( $\mu \alpha \sigma \tau \imath \gamma \omega \theta \varepsilon i ́ s)$ during the interrogation (anakrisis) at his trial ${ }^{123}$. We take this

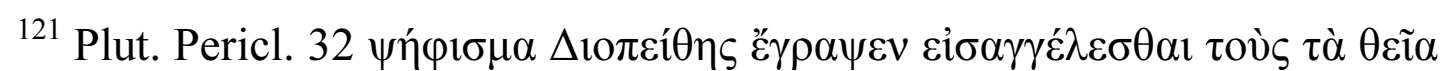

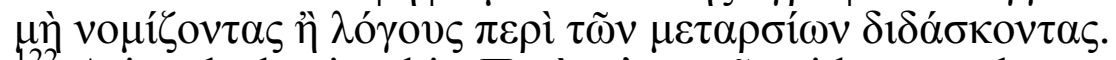

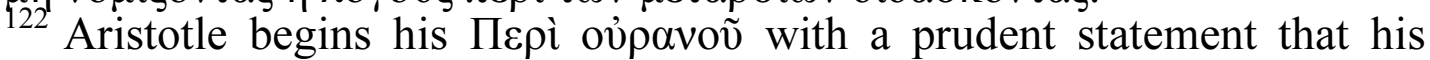
views on the divinity of Heavens are in perfect agreement with «ancestral

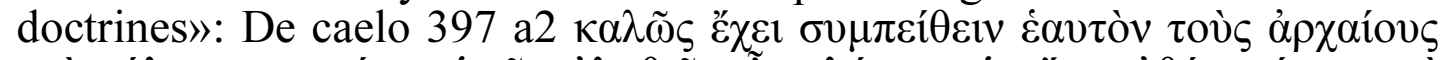

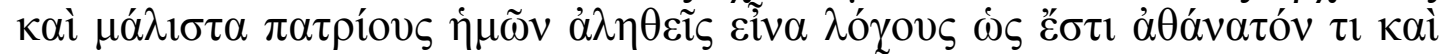

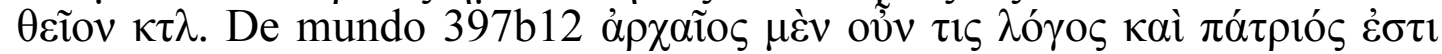

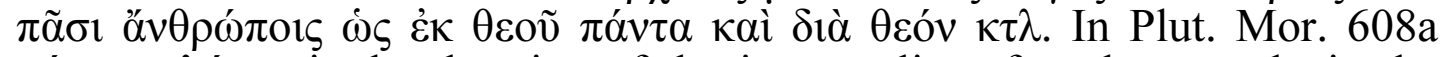
$\pi \alpha$ áp mysteries of Dionysus.

${ }_{123}$ See Vassallo 2018/2019, test. (7) = Philodem. Rhet.IV, PHerc. 245, fr. 7 
evidence at its face value as a historical fact since it comes from a series of trials of phlosophers the historicity of which cannot be doubted. The new evidence sheds new light on the meaning of two cryptic Tantalos passage in Euripides' Orestes (4-10 and 982-84). We interpret them as a cryptic commemoration of the 20th anniversary of Anaxagoras' death disguised as a parabel about the punishment of the «ancient physiologos» Tantalos by Zeus for his licentious tongue (ákó $\lambda \alpha \sigma \tau \sigma \zeta \gamma \lambda \omega ́ \sigma \sigma \alpha)$ : the Tantalos' «rock» hanging over his head is conceived as Anaxagorean lump (bolos) of the sun. The «tortures» of the mythical Tantalos allude to the real tortures of Anaxagoras at this trial, and the «rock» that still hangs over the heads of those who investigate the nature of the stars, is the charge of impiety. "Zeus» that punishes audacious physiologoi alludes to the «Servant of Zeus» Dio-peithes who punished Anaxagoras by his psephisma. In a kind of makarismos Anaxagoras is praised by Euripides as an innocent martyr of science and a victim of the religious fanaticism ${ }^{124}$. It is tempting to take the grotesque $\alpha$ idoiov

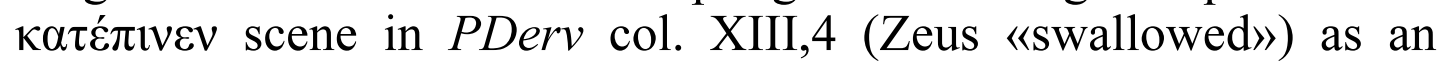
obscene joke intended by Prodicus as a personal insult of Diopeithes whose name etymologically means «the one who obeys Zeus». Prodicus was the leading expert in language and style of his time, it is inconceivable that he so blatantly misread a perfectly clear text in

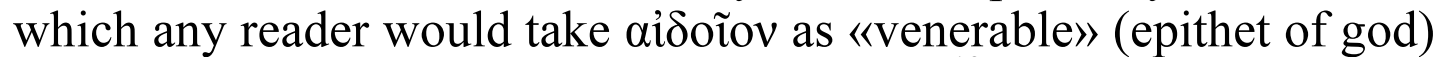
rather than as a substantive meaning penis ${ }^{125}$. After Anaxagoras' exile Archelaus becomes the leading figure in the post-Anaxagorean physiologia in Athens. It is around this time that the book of Heraclitus becomes fashionable in the Socratic and Sophistic circles

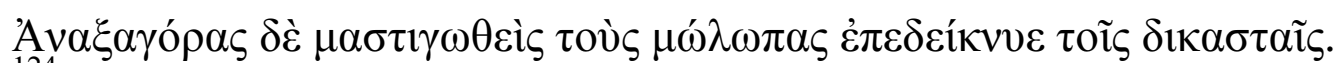

${ }^{124}$ For a detailed discussion of the Tanatlos' paradigm in Orestes see Lebedev 2019: section VIII, cf. Willink 1983.

${ }_{125}$ Contra Burkert 1980: 32; Kirk 1983: 32-33; Janko 2001: 24; Betegh

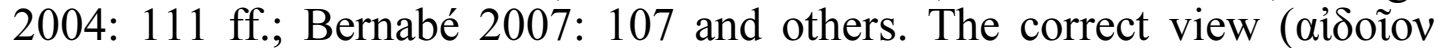

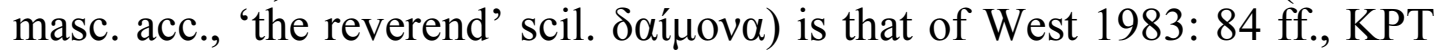
2006: 133 and Sider 2014: 231, among others. A detailed and persuasive refutation in Santamaria 2016. Sider 2014: 241 has pointed out to the important fact neglected by the supporters of the former view, that the sing.

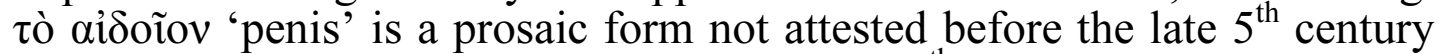
(Hippocr., Herod.) and therefore unlikely in a $6^{\text {th }}$ century B.C. epic poem.

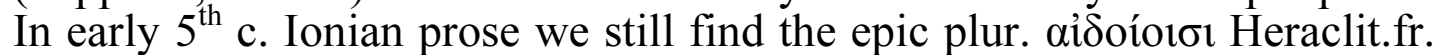
$148 \mathrm{~L} / \mathrm{B}$ 15. The masculine pronoun ös in XIII, 4 alone makes it clear that

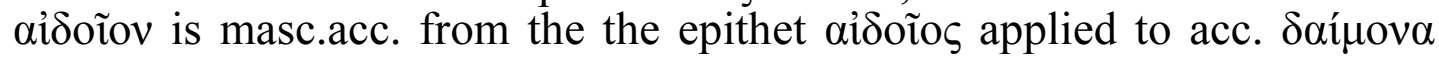

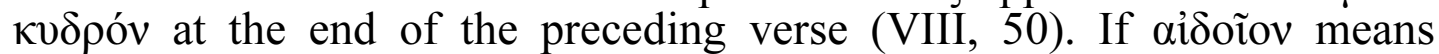
'penis', then Olympos means 'time', Okeanos means 'air', Moira of Zeus means 'vortex in the air' and so on. 
in Athens. Euripides and Socrates are among the first readers (D.L.2.22 = A4 DK); Prodicus was connected with both. Prodicus and Euripides were friends and both of them were disciples of Anaxagoras. After the death of Anaxagoras in 428 B.C. they probably joined their efforts in a counter-attack against Diopeithes and $\mathrm{C}^{\mathrm{o}}$. in order to restore the immaculate name of Anaxagoras and to absolve him from the false accusations of impiety. The author of De diaeta I (possibly Herodicus of Selymbria) (Lebedev 2014: 2842) in his cosmology and physics exhibits a strikingly similar synthesis of Anaxagoras and Heraclitus phrased in a strikingly similar language; on independent grounds we date it to the same decade 430-420 B.C. (Lebedev 2014: 27-42). Possible influences of Democritus (a close associate of Prodicus' teacher Protagoras) on PDerv during or after his visit to Athens in the twenties would also support our date ${ }^{126}$. It is reasonable to suppose that Prodicus was nicknamed Tantalos after he wrote Horai (DervTr). Willink arrives at 420-410 B.C. (between Aristophanes' Clouds and Euripides' Orestes) as the most plausible date of Prodicus' sobriquet Tantalos (Willink 1983: 33).

\section{(7) Explanatory notice on the use of terms "peritrope» and «monism/pluralism».}

A. Peritrope as a polemical device in Greek philosophy and the Derveni papyrus.

In the beginning of this article we have described as a peritrope the polemical substitution of the ethico-religious pantheism of the Orphic theogony by the naturalistic (irreligious) pantheism of the Derveni author. We use this term in a peculiar way that requires a clarification. In ancient logic and dialectic $\pi \varepsilon \rho \iota \tau \rho o \pi \eta$ was a term for the self-refuting arguments (on this subject see Castiglione 2010). A self-refuting argument differs from the ordinary refutation in that it takes the thesis of the opponent as a premise. Sextus Empiricus applies the term $\pi \varepsilon \rho \imath \tau \rho \pi \eta$ to Plato's and Democritus' refutation of Protagoras' homo-mensura thesis in its Platonic interpretation «every opinion ( $\delta$ '́ $\xi \alpha$ ) is true»: if every opinion is true, than the opinion that not every opinion is true, is true as well. From which it follows that not every opinion is true, i. e. that Protagoras' thesis $\pi \varepsilon \rho \iota \tau \rho \varepsilon ́ \pi \varepsilon \tau \alpha \imath$ «turns around» and refutes Protagoras. We use peritrope as a modern hermeneutical term (suggested of course by

${ }^{126}$ We argue for the possible influence of Democritus (not «Leucippus») on DervT in Lebedev 2019: section VI. 
Greek dialecticians), in a wider sense to denote a polemical device in Greek philosophical culture of debates: one of the theoretical opponents borrows from the other his own characteristic term, image, idea, theory, form of thought, even a literary genre etc. and «turns it around» against him by «recharging it» with a contradictory poemical content. In the debate between the "Anaxagoreioi and Pythagoreioi» in Athens at the time of the Peloponnesian war the "Anaxagorean» Derveni author (Prodicus) borrowed from the opponents the figure of Orpheus, his teletai, his «Hieros logos» and «turned around» all this against them. A philosophical peritrope sometimes may contain elements of parody, but unlike e.g. parodies of Timon, it is a serious polemical device, nay it is a driving force of the dialectical development of thought. The history of Greek philosophy is an inexhaustible source of peritropai. Here are just a few. Heraclitus' new teleological and theological concept of physis identified with a providential god was a polemical peritrope of the mechanistic concept of physis in Anaximander. Pythagoras' doctrine of the immortality of the soul was a polemical peritrope of the Milesian law of the indestructibility of matter. Parmenides borrowed the epic language and metre from Homer and Hesiod not because he wished to continue the epic tradition, but because his aim was to replace the epic polytheism and anthropomorphism of the immoral Hometic gods with the new Pythagorean god, a sphaera of the divine mind and justice described

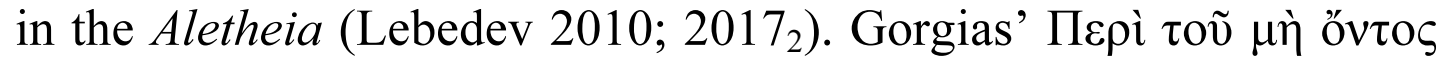
was, in turn, a peritrope (and a parody) of Parmenides' deductive metaphysics. Plato's geometrical atomism in the «Timaeus» was a peritrope of the physical atomism of Democritus, an immaterialist theory of matter etc.

Two types of peritrope should be distinguished: a deconstructive peritrope whose aim is primarily to destroy the thesis of an opponent, and a constructive or synthesising peritrope which incorporates the opponent's thesis into a new theory, subordinates it to a new synthetic structure and makes it to serve a different purpose, i. e. «enslaves it». Gorgias' peritrope of Parmenides' ontology and the Derveni author's (Prodicus') peritrope of the Orphic theogony are crystal-clear examples of the first type. Heraclitus' theologicalteleological peritrope of the Milesian concept of physis, Aristotle's peritrope of the transcendental noetic Platonic forms as immanent forms of the physical world, Plato's subordination of Democritus' precosmic motion of matter to the dictates of the Pythagorean divine mind-demiourgos provide examples of the second type. 


\section{B. Explanatory notice on the use of the terms «monism»,} «dualism», «pluralism».

When we write above in section 3 (cf. note 84) about «the battle of ideas between the Ionian naturalists (adepts of the naturalistic monism) and religiously minded dualists» in 5th century Athens we use the term «monism» in its traditional philosophical sense of the metaphysical school of thought that recognises only one kind of reality and is opposed to the metaphysical dualism that recognises two kinds (corporeal and incorporeal, god and matter etc.). Metaphysical monism can be naturalistic (only physis exists) and idealist or mentalist (only mind exists) also known as immaterialism. Most Ionian physikoi and Ionian sophists were naturalistic monists, the Pythagoreans were dualists, Parmenides was an idealist monist or immaterialist ${ }^{127}$. Some scholars apply the term «monism» to oneelement theories of matter and counterpose the adepts of such theories (dubbed «monists», e.g. Anaximenes) to many-elements theories of matter held by «pluralists» (such as Empedocles and Anaxagoras). This unphilosophical use of the terms monism/pluralism (that probably derives from some ancient doxographical passages of the problem of «one and many») is potentially misleading and can result in confusion of taxonomy of metaphysical theories of kinds of reality and taxonomy of physical theories of matter or physical elements. Corpuscular theories of matter (such as those of Anaxagoras and Democritus) should not be called «pluralist» and should not be contrasted with «monistic» theories of single material continuum. They should be called corpuscular theories and contrasted with single-substrate or one-element theories of matter. Corpuscular theories of matter may also be contrasted with singlesubstrate theories of matter, discrete theories of matter may be distinguished from continualist theories. What matters in metaphysics and in history of ancient metaphysics is the perennial conflict of the naturalistic monism and metaphysical dualism of body and the mind, god and matter etc. Who are the metaphysical «pluralists», we do not know and would be grateful to anyone who would solve to us this aporia. Aristotle's four causes should not be cited as example since these are not fours substances, but aspects of ousia or explanatory approaches to ousia. Middle Platonic doxography of «three principles» in Plato (god, matter, idea)? But

${ }^{127}$ The doctrine of the identity of being and mind is directly stated by Parmenides in fr. B 3. For a detailed refutation of the grammatically impossible interpretation of Burnet and his followers see Lebedev 2017. 
historical Plato was a dualist. Democritus recognised an infinite number of atoms, but he regarded them all as one physis («as if each was a separate particle of gold») ${ }^{128}$; he was a strict naturalistic monist who ridiculed Anaxagoras' theory of the cosmic mind as a concession to creationism. The Derveni author (Prodicus) seems to follow Archelaus' «immanent» version of the theory of the cosmic mind and therefore looks like a naturalistic monist. Both Empedocles and Anaxagoras should be classed as dualists (not as «pluralists»), though the precise nature of Anaxagoras' nous remains uncertain and a subject of endless debates. We believe that the fundamental thesis of the Greek philosophical theology, the identification of god with mind (voṽ $\varsigma$ ) goes back to the sixth century and may be of Pythagorean origin. In the late sixth - early fifth century B.C. it is attested in Epicharmus (in a parody of Pythagorean theology), Xenophanes and Parmenides (on Epicharmus see Lebedev 2017, Xenophanes B 24-25 and Lebedev 1985). If our reconstruction of the text of Heraclitus' fragment 140L is correct (as we believe it is ${ }^{129}$, the theory of the divine cosmic mind existed before Anaxagoras not only in the West, but also in the Ionian tradition itself. It is therefore conceivable that Anaxagoras derived his concept of the cosmic mind from Heraclitus rather than from the Italian philosophers (however, the influence of both traditions cannot be ruled out). Heraclitus' teleological cosmotheism was directed against Anaximander's mechanistic theory of matter and the «vortex» cosmogony (Lebedev 1988; 2016: 597-98). Anaxagoras tried to reconcile and to synthesize these two conflicting theories and world-views: he took the mechanistic corpuscular theory of matter as «mixture» from Anaximander (a nightmare for Heraclitus!) and the cosmic mind from Heraclitus, and made the mind trigger the vortex mechanism of «separation» and world-formation. The Western and the Heraclitean theories of the divine cosmic mind are based on different types of metaphysics: in the dualist meta-

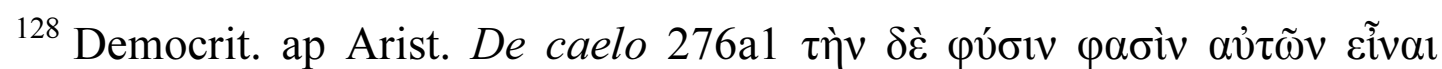

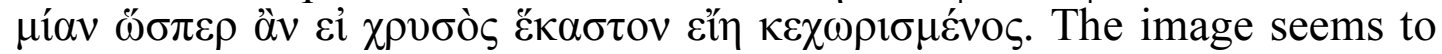
be authentic.

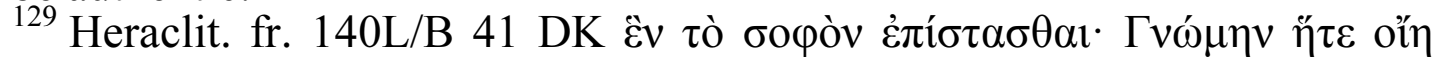

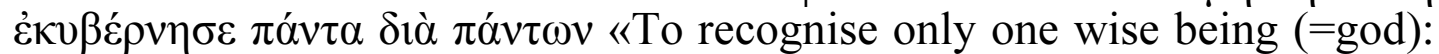
that Mind which alone steers the whole Universe». Гvต́ $\mu \eta$ is a regular word for «mind, intelligence» in Corpus Hippocraticum (101 instances). The word has been often mistranslated as «thought, plan» etc. because of the wild text printed in DK. The form ó $\tau \varepsilon ́ \eta$ is not only unattested, it cannot be even imagined. In the first edition of Herakleitos Diels correctly translated $\gamma v \omega ́ \mu \eta$ as «Intelligenz» and so did Jacob Bernays. 
physics of Magna Graecia the god-mind was «separated» from matter (corporeal substance) and opposed to it as a creative (demiourgic) element to a formless and passive principle, in Heraclitus' strictly monistic pantheism god and physis were identified, and

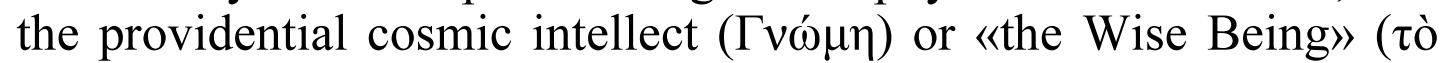

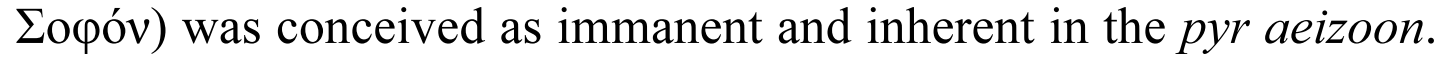
It is conceivable therefore that in his theory of the cosmic mind the Derveni author was influenced not only by Anaxagoras and Archelaus, but also by Heraclitus. However, it should be stressed that Heraclitus' cosmic god is personal, providential and relevant both ethically and religiously; the Stoics were genuine Heracliteans in their pantheistic theology, as in their philosophy of nature and ethics. To our knowledge there is no indication in the sources that Anaxagoras' cosmic nous was conceived as a providential personal god who cares for humans and with whom they can communicate through prayer and worship. And it was dismissed both by Plato and Aristotle because they sensed the artificial character of this synthesis and the «deistic» character of Anaxagoras' nous (never called $\theta \varepsilon$ co $\varsigma$ in the extant fragments). It remains unclear whether the Derveni author understood the difference between Anaxagoras' and Heraclitus' versions of the theory of cosmic mind, e.g. when he quotes in col. IV the sun fragment which proves the existence of the cosmic mind by the regularity of solstices.

\section{Bibliography}

Ademollo, Fr. 2011: The Cratylus of Plato. A Commentary, Cambridge.

Ahmadi, A. 2014: The Magoi and Daimones in Column VI of the Derveni Papyrus. Numen 61, 484-508.

Ambrose, Z. Ph. 1982: Socrates and Prodicus in the Clouds. In: Anton, J., Preus, A. (edd.). Essays in Ancient Greek Philosophy. Vol. 2. New York, $129-144$.

Bargomi, M. 2014: Some considerations on the presence of Derveni allegory in Plato's Cratylus. Methexis XXVII, 215-224.

Barney, R. 2001: Names and Nature in Plato's Cratylus. New York; London.

Baxter, T. 1992: The Cratylus. Plato's Critique of Naming. Leiden; New York.

Bernabé PEG = Bernabé, A. 2004-2007: Poetae epici Graeci: Testimonia et fragmenta. Pars 2, fasc. 1-3, Berlin.

Bernabé, A. 2007a)।: The Derveni Theogony: Many Questions and Some Answers. Harvard Studies in Classical Philology 103, 99-133.

Betegh, G. 2004: The Derveni Papyrus: Cosmology, Theology, and Interpretation. Cambridge.

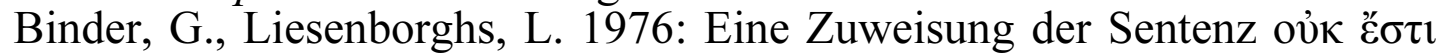

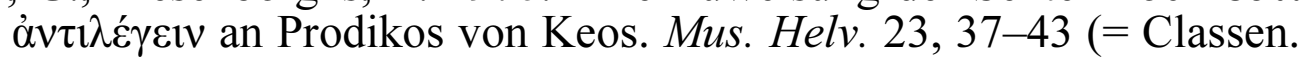


J. C. (ed.). 1976: Sophistik. Darmstadt, 453-462).

Boyance, P. 1974: Remarques sur le papyrus de Derveni. Rev. Et. Gr. 82, 91-110.

Bremmer, J. D. 2014: Initiation onto the Mysteries of the Ancient World. Berlin: Boston.

Brisson, L. 2004: How Philosophers Saved Myths. Allegorical Interpretation and Classical Mvthologv. Chicago.

Brisson, L. 2009: Zeus did not commit incest with his mother. An interpretation of Column XXVI of the Derveni papyrus. ZPE 168, 27-39.

Burkert, W. 1968: Orpheus und die Vorsokratiker. Bemerkungen zum Derveni-Papyrus und zur pythagoreischen Zahlenlehre. Antike und Abendland 14, 93-114 (= K1. Schr. III, 62-94)

Burkert, W. 1985: Greek Religion. Harvard, Mass.

Burkert, W. 1986: Der Autor von Derveni: Stesimbrotos ПEPI TE $\Lambda$ ET $\Omega$ N. ZPE 62, 5 .

Byl, S., Couloubaritsis, L. (edd.) 1995: Mythe et philosophie dans les Nuées d'Aristophane.

Byl, S. 2013: Les nuées d'Aristophane: une initiation à Eleusis en 423 avant notre ère. In: Byl, Couloubaraitsis 1995, 11-68.

Castiglione, L. 2010: Ancient Self-Refutation. Cambridge.

Cole, Th. 1990: Democritus and the sources of Greek anthropology. Atlanta.

Dean Anderson Jr., R. 2000: Glossary of Greek Rhetorical Terms. Leuven.

Denniston, J. D. 1952: Greek Prose Style. Oxford.

Devine, A. M., Stephens, L. D. 2000: Discontinuous Syntax. Hyperbaton in Greek. Oxford.

Diels, H., Kranz, W. Die Fragmente der Vorsokratiker. Bde. 1-3. Weidmann'sche Verlagsbuchhandlung.

Dieterich, A. 1911: Über eine Szene der Aristophanischen Wolken. In: Kleine Schriften. Leipzig, Berlin, 117-124.

Dodds, E.1960: Euripides. Bacchae. Oxford.

Dover, K.1968: Aristophanes, Clouds. Oxford.

Dressler, J. 2014: Wortverdreher, Sonderlinge, Gottlose. Kritik an Philosophie und Rhetorik im klassischem Athen. Berlin; Boston.

Edmonds, R. G. 1999: Tearing apart the Zagreus myth. Classical Antiquity $18(1), 35-73$.

Edmonds, R. G. 2013: Redefining Ancient Orphism. Cambridge.

Ferrari, F. 2007: Note al testo delle colonne II-VII del papiro di Derveni. ZPE 162, 203-211.

Fränkel, H. 1938: A Thought Pattern in Heraclitus. AJPh 59, 339-337.

Furley, W. D. 1985: The Figure of Euthyphro in Plato's Dialogue. Phronesis XXX, 201-208.

Gagné, R. 2007: Winds and Ancestors: the Physika of Orpheus. HSCP 103, $1-24$.

Gianakis, G. K. 2014: Encyclopedia of Ancient Greek Language and Linguistics. Vol. 2. Leiden; Boston.

Gary Miller, D. 2013: Ancient Greek dialects and early authors. Boston; Berlin. 
Graf, F. 1974: Eleusis und die Orphische Dichtung Athens in vorhellenistische Zeit. Berlin.

Gray, V. 2006: The Linguistic Philosophies of Prodicus in Xenophon's «Choice of Heracles»? The Classical Quarterly 56 (2), 426-435.

Guthrie, W. K. C. 1969: A History of Greek Philosophy. Vol. 3, Part 1. The Sophists. Cambridge University Press.

Henrichs, A. 1975: Two Doxographical Notes: Democritus and Prodicus on Religion. Harvard Studies in Classical Philology 79, 93-123.

Henrichs, A. 1976: The Atheism of Prodicus. Cronache Ercolanesi 6, 15- 21.

Henrichs, A.1984: The Sophists and Hellenistic Religion: Prodicus as the Spiritual Father of the ISIS Aretalogies. Harvard Studies in Classical Philology 88, 139-158.

Henrichs, A. $1984_{1}$ : The Eumenids and wineless libations in the Derveni papyrus. In: Atti del XVII convento internazionale di papirologia. Napoli, 255-268.

Hussey, E. 1999: The enigmas of Derveni. Oxford Studies in Ancient Philosophy 17, 303-324.

Irigoin, J. (1972): Les manuscripts grecs, II. Nouveaux recueils des facsimilés. $R E G$ 85, 543-571.

Janko, R. 1997: The physicist as hierophant: Aristophanes, Socrates and the authorship of the Derveni papyrus. ZPE 118, 61-94.

Janko, R. 2001: The Derveni Papyrus (Diagoras of Melos, Apopyrgizontes Logoi?): A New Translation. Classical Philology 96, 1-32.

Janko, R. 2002: The Derveni Papyrus: An Interim Text. Zeitschrift für Papyrologie und Epigraphik 141, 1-62.

Janko, R. 2016: Parmenides in the Derveni Papyrus: New Images for a New Edition. ZPE 193, 1-21.

Johnston, S. I. 2014: Divination in the Derveni Papyrus. In: Papadopoulou, Muellner 2014: 89-105.

Kahn, Ch. 1981: The Art and Thought of Heraclitus. Cambridge.

Kahn, Ch.1997: Was Euthyphro the Author of the Derveni Papyrus, in: Laks, A., Most, G. Studies in the Derveni Papyrus. Oxford, 55-69.

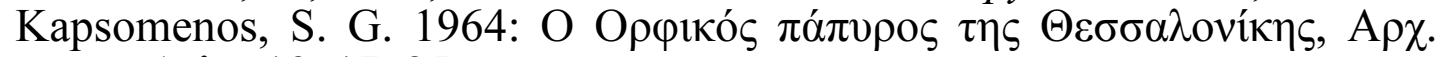
$\Delta \varepsilon \lambda \tau .19,17-25$.

Kilarski, M. 2013: Nominal classification. A history of its study from the classical period to the present.

Konaris, M. D. 2016: The Greek Gods in Modern Scholarship. Oxford.

Kotwick, M. 2017: Der Papyrus von Derveni: Griechisch-deutsch.

Kotwick, M, 2016: Notes on PDerveni cols. XV, XIX, XXII and XXIV. ZPE 197, 1-4.

KPT $=$ Kouremenos, Th., Parassoglou, G., Tsantsanoglou, K. (edd.) 2006: The Derveni Papyrus. Firenze (= Studi e testi per il corpus dei papiri filosofici greci e latini, 13).

Laks, A., Most, G. 1997: Studies on the Derveni Papyrus. Oxford.

Lebedev, А. 1978: TO AПEIPON: Not Anaximander, but Plato and Aristotle. Vestnik Drevnei Istorii [A Journal of Ancient History] 1, 39-54.

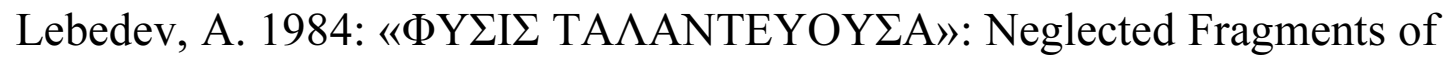
Democritus and Metrodorus of Chios. In: Proceedings of the First International Congress on Democritus II. Xanthi, Greece, 13-25. 
Lebedev, A. 1985: A New Fragment of Xenophanes. In: Capasso, M., de Martino, Fr., Rosati, P. (ed.). Studi di Filosofia Preplatonica. Napoli, 13-15.

Lebedev, A. 1985 : The Cosmos as a Stadium: Agonistic Metaphors in Heraclitus' Cosmology». Phronesis. A Journal for Ancient Philosophy 33 (2), 131-150.

Lebedev, A. 1988: Anaximander the originator of the mixis theory of matter and the founder of mechanistic physics. In: First International Conference on Greek Philosophy. Ionian Philosophy. Samos, 27-31 August 1988 - Pythagoreion, Abstracts of papers, p. 56-57.

Lebedev, A. 1989: Fragmenty rannih grecheskih filosofov. [The fragments of the Early Greek Philosophers]. Moscow.

Lebedev, A. 1989 1 : Heraclitus in P.Derveni. ZPE 79, 39-47.

Lebedev, A. 1996: Pharnabazos the diviner of Hermes. Two ostraka with curse-letters from Olbia. ZPE 112, 268-278.

Lebedev, A. 1998: The Justice of Cheiron (Titanomachia fr. 6 and 11 B.). Philologus 142, 3-10.

Lebedev, A. 2010: Western Greek Philosophical Poems and the Homeric Tradition: Continuity or Rupture? Indoevropeiskoe yazykoznanie $i$ klassicheskaya filologiya [Indo-European linguistics and classical philology] 14, 101-110.

Lebedev, A. 2014: Logos Geraklita. Rekonstrukciia mysli i slova. S novym kriticheskim izdaniem fragmentov [The Logos of Heraclitus: A Reconstruction of his Thought and Word. With a New Critical Edition of the Fragments]. St-Peterburg: Nauka.

Lebedev, A. 2015: The «Theogony» of Epimenides of Crete and the Origin of the Orphic-Pythagorean Doctrine of Reincarnation. Indoevropeiskoe yazykoznanie $i$ klassicheskaya filologiya [Indo-European linguistics and classical philology] 19, 464-498 (in Russian with English summary).

Lebedev, A. 2016: Lebedev A.V. The Origin and Transmision of the Doxographical Tradition Placita Philosophorum (Arius Didymus, Ps.Plutarch, Stobaeus, Theodoret, Nemesius, Porphyrius). Indoevropeiskoe yazykoznanie i klassicheskaya filologiya [Indo-European linguistics and classical philology] 20 (2), 573-633.

Lebedev, A. 2017,: The Metaphor of Liber Naturae and the Alphabet Analogy in Heraclitus' Logos Fragments (With some remarks on Plato's «dream theory» and the origin of the concept of elements). In: E. Fantino, U. Muss, Ch. Schubert, K. Sier (Hrsg.). Heraklit im Kontext. Berlin; New York: Walter de Gruyter, 233-269 (= Studia Praesocratica 8).

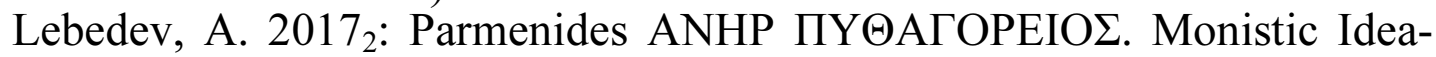
lism (Mentalism) in Archaic Greek Metaphysics. Indoevropeiskoe yazykoznanie i klassicheskaya filologiya [Indo-European linguistics and classical philology] 21, 493-536.

Lebedev, A. 2017 : Alcmaeon of Croton on Human Knowledge, the Seasons of Life and Isonomia. Two Additional Frgaments from Turba Philosophorum and Aristotle. In: Chr. Vassallo (ed.). Physiologia. Topics in Presocratic Philosophy and its Reception in Antiquity. Trier, 227-257. 
Lebedev, A. 20174: Epicharmus on God as Mind (NOOE). A Neglected Fragment in Stobaeus. (With some remarks on early Pythagorean metaphysics and theology). Artisteas XVI, 13-27.

Lebedev, A. 2019: The Derveni Papyrus: A Sophistic Treatise on the Origin of Religion and Language. The authorship of Prodicus of Ceos. In: Chr. Vassallo (ed.). Presocratics and Papyrological Tradition. Section VII. Berlin; Boston (forthcoming).

Long, A. 1996: Stoic Studies. Berkeley.

Luria, S. 1928: Wann hat Demokrit gelebt? Archiv für Geschichte der Philosophie 38, 205-238.

Luria, S. 1947: Ocherki po istorii antichnoi nauki [Essays on the history of the ancient science]. Moscow; Leingrad.

Luria, S. 1970: Democritea. Leningrad.

Mansfeld, J. 1980: The chronology of Anaxagoras' Athenian period and the date of his trial II. Mnemosyne 33, 88.

Mansfeld, J. 1983: Cratylus 402 A-C: Plato or Hippias? In: Atti del Symposium Heracliteum 1981. Roma, 43-55.

Mayhew, R. 2013: Prodicus the Sophist. Texts, Translations, and Commentary. Oxford.

Montanari, F, Matthaios, S., Rengakos, A. (edd.) (2015): Brill's Companion to Ancient Greek Scholarship. Vol.1, Leiden; Boston.

Mouraviev, S. N. 1985: The Heraclitean Fragment of the Derveni Papyrus. ZPE 61, 131-132.

Müller, F. M. 1885: Lectures on the Science of Language. Vol. 1, London.

Nails, D. 2002: The people of Plato. A prosopography of Plato and other Socratics. Indianapolis; Cambridge.

Nestle, W. 1936: Die Horen des Prodikos. In: Classen C. J. (Hrsg.) Sophistik. Darmstadt, 425-451.

Obbink, D. 1994: A Quotation of the Derveni Papyrus in Philodemus' «On Piety». In: Cronache Ercolanesi 24, 110-135.

Obbink, D. 1996: Philodemus On Piety. Part I: Critical Text with Commentary. Oxford.

Obbink, D. 1997: Cosmology as Initiation vs. the Critiques of Orphic Mysteries. In: Laks and Most (eds.), 39-54.

Papadopoulou I. and Muellner L. (edd.). 2014: Poetry as Initiation. Washington D.C.

Parker, Robert (1992): The Origins of Pronoia: A Mystery, in: Apodosis, London, 84-94.

Penella, R. J. (tr.). 2000: The Private Orations of Themistius. Berkeley.

Piano, V. 2016: P. Derveni iii-vi: una riconsiderazione del testo, ZPE 197, $5-16$.

Pendrick, G. J. 2002: Antiphon the Sophist. The Fragments. Cambridge.

Reesor, M. 1983: The Stoic Idion and Prodicus' Near-Synonyms. AJPh 104 (2), 124-133.

Riedweg, C. (1987): Mysterienterminologie bei Platon, Philon und Klemens von Alexandrien. Berlin and New York.

Rijlaarsdam, J. C. 1978: Platon über die Sprache. Utrecht.

Rogers, B. B. 1930: The Clouds of Aristophanes. London.

Roubekas, N. 2016: An Ancient Theory of Religion: Euhemerism from Antiquity to the Present. 
Roux, J. 1972: Euripide, Les Bacchantes II, Commentaire. Paris.

Rubel, A., Vickers, M. 2014: Fear and Loathing in Ancient Athens: Religion and Politics During the Pelopponesian War. Routledge.

Rusten, J. S. 1985: Interim Notes on the Papyrus from Deeveni. HSPh 89, $121-140$.

Sansone, D. 2004: Heracles at Y. The Journal of Hellenic Studies 124, $125-142$.

Santamaria, M. 2010: Tiresias in Euripides' Bacchae and the author if the Derveni papyrus. In: Schubert, P. (ed.). Actes du $26^{e}$ Congrès international du papyrologie. Genève, 677-684.

Santamaria, M. 2016: A Phallus Hard to Swallow: the Meaning of $\mathrm{AI} \Delta \mathrm{OIO} \Sigma /-\mathrm{ON}$ in the Derveni Papyrus. Classical Philology 111, $139-164$.

Scholten, H. 2003: Die Sophistik: eine Bedrohung für die Religion und Politik der Polis. Berlin.

Sedley, D. 2003: Plato's Cratylus. Cambridge.

Sedley, D. 2013: From the Pre-Socratics to the Hellenistic Age. in: Bullivant, S., Ruse, M. (edd.). The Oxford Handbook of Atheism. Oxford.

Sider, D. 1997: Heraclitus in the Derveni Papyrus. In: Laks, A., Most, G. (edd.). Studies in the Derveni Papyrus. Oxford, 129-148.

Sider, D. 2014: The Orphic Poem of the Derveni Papyrus. In: Papadopouloou, I., Muellner, L. (edd.). Poetry as Initiation. The Center of Hellenic Studies Symposium on the Derveni Papyrus. Washington, DC.

Starkie, W. J. M. (ed.). 1911: The Clouds of Aristophanes. London.

Taillardat, J. 1962: Les images d'Aristophane. Paris.

Tzifopoulos, Y. 2014: The Derveni Papyrus (PDerveni) and the BacchicOrphic Epistomia. in: Papadopolulou, Muellner 2014, chapter 8.

Usener H., Gigante M., Schmid W. 1977: Epicurus. Glossarium Epicureum. Rome: Edizioni dell' Ateneo and Bizzarri.

Vassallo, Chr. 2018/2019: Anaxagoras from Egypt to Herculaneum: A Contribution to the History of Ancient Atheism. In: Doxographica Anaxagorea in Papyris Reperta, collegit, Disposuit et restituit Christan Vassallo. In: Vassallo, Chr. (ed.). Presocratics and Papyrological Tradition. Berlin; Boston.

West, M. 1983: The Orphic Poems. Oxford.

West, M. 2013: The Writing Tablets and Papyrus from Tomb II in Daphni. In: Greek and Roman Musical Studies 1, 73-92.

Willi, A. 2010: Attic as the Language of the Classics. in: Caragounis, C. (ed.). Greek: A Language in Evolution. Hildesheim, 101-118.

Willink, C. W. 1983: Prodicus, «Meteorosophists» and the «Tantalos paradigm». Classical Quarterly, New Series, 33 (1), 25-33.

Winiarczyk, M. (ed.). 1981: Diagoras Melius. Theodorus Cyrenaeus (BT). Lipsiae.

Winiarczyk, M. 2016: Diagoras of Melos. A Contribution to the History of Ancient Atheism. Berlin.

Winspear, Alban D. and Silverberg, Tom (1960): Who was Socrates?, New York.

ZPE 1982 = Anonymi. Der orphische Papyrus von Derveni. Zeitschrift für Papyrologie und Epigraphik 47, 1*-12* (following 300) 
Summary. Section (1) explains why the Deveni papyrus has often been misunderstood: among the main reasons are the wrong label «Orphic» and the confusion of two types of pantheism in Greek thought: the ethicoreligious and the naturalistic. The Orphic hymn to Zeus is a classical example of the first type, the Derveni commentary - of the second which is incompatible with the immortality of the soul and afterlife. Section (2) deals with the literary genre, the general purpose and the hermeneutical method of the Derveni treatise, and draws a preliminary intellectual portrait of its author describing his peculiar features, a kind of a «composite image». In the section (3) we argue for Prodicus as the author of PDerv and present 18 testimonia on which this attribution is based. These include both the verbatim quotations with Prodicus' name that find an exact correspondence in the text of PDerv and the common peculiar features of the language and style. In the section (4) we propose a reconstruction and interpretation of the text of the col. IV that contains a quotation from Heraclitus. This column is of primary importance for the understanding of the aims and allegorical method of the author in general as well as for his theory of names. Section (5) detects a neglected (polemical) peritrope of Prodicus' benefaction theory of the origin of religion in Xenophon's Memorabillia 4.4. In the section (6) the problems of the original title and date of the Derveni treatise are addressed, its relation to the Psephisma of Diopeithes (432 BC) as well as to the trial and death of Anaxagoras. The last section (7) clarifies our use of the term peritrope and explains the Derveni treatise as a polemical naturalistic peritrope of a religious text (Orphic theogony).

Key-terms: Ancient philosophy, Derveni papyrus, Prodicus, Sophists, Orphism, Orpheus, Anaxagoras, Archelaus, Heraclitus, theogony, origin of civilisation, origin of religion, origin of language, origin of mythology, allegory, psephisma of Diopeithes, ancient atheism, Greek Enlightenment, philosophy of language, ancient Athens. 